\title{
Nest-site resources for cavity-nesting birds in the southern Allegheny Mountain forests of West Virginia
}

Harry A. Kahler

West Virginia University

Follow this and additional works at: https://researchrepository.wvu.edu/etd

\section{Recommended Citation}

Kahler, Harry A., "Nest-site resources for cavity-nesting birds in the southern Allegheny Mountain forests of West Virginia" (2002). Graduate Theses, Dissertations, and Problem Reports. 1478.

https://researchrepository.wvu.edu/etd/1478

This Thesis is protected by copyright and/or related rights. It has been brought to you by the The Research Repository @ WVU with permission from the rights-holder(s). You are free to use this Thesis in any way that is permitted by the copyright and related rights legislation that applies to your use. For other uses you must obtain permission from the rights-holder(s) directly, unless additional rights are indicated by a Creative Commons license in the record and/ or on the work itself. This Thesis has been accepted for inclusion in WVU Graduate Theses, Dissertations, and Problem Reports collection by an authorized administrator of The Research Repository @ WVU. For more information, please contact researchrepository@mail.wvu.edu. 
NEST-SITE RESOURCES FOR CAVITY-NESTING BIRDS

IN THE SOUTHERN ALLEGHENY MOUNTAIN

FORESTS OF WEST VIRGINIA

Harry A. Kahler

Thesis submitted to the

Davis College of Agriculture, Forestry and Consumer Sciences at West Virginia University

in partial fulfillment of the requirements

for the degree of

Master of Science

in

Wildlife and Fisheries Resource Management

James T. Anderson, Ph.D., Chair

Ray R. Hicks, Ph.D.

James Rentch, Ph.D.

Division of Forestry

Morgantown, WV

2002

Keywords: southern Allegheny Mountains, cavity-nesting birds, northern hardwood, central hardwood, West Virginia, Monongahela National Forest

Copyright 2002 Harry A. Kahler 


\section{ABSTRACT \\ NEST-SITE RESOURCES FOR CAVITY-NESTING BIRDS \\ IN THE SOUTHERN ALLEGHENY MOUNTAIN \\ FORESTS OF WEST VIRGINIA}

\section{HARRY A. KAHLER}

Cavity-nesting birds may be negatively impacted by a lack of proper nesting sites. Southern Allegheny Mountain forests of West Virginia are unique due to the juxtaposition and diversity of forest cover types. Management must focus on monitoring wildlife population levels as well as habitat requirements within each cover type. Cavity tree abundance significantly differed among central hardwood $(\overline{\mathrm{x}}=16.4 ; \mathrm{SE}=5.3)$, northern hardwood $(\overline{\mathrm{x}}=12.7 ; \mathrm{SE}=6.8)$, and boreal forest cover types $(\overline{\mathrm{x}}=7.2 ; \mathrm{SE}=3.6)$ $(P<0.0001)$. Black locust (Robinia pseudoacacia) and American beech (Fagus grandifolia) were most likely to have tree cavities, yet beech may be influenced by increased mortality from recent outbreaks of beech bark disease initiated by the beech scale insect (Cryptococcus fagisuga). Nesting bird community density, richness, and abundance do not differ among mature forests of the 3 cover types. Cavity-nesting species dependent on available tree holes were found most in the central hardwoods $(P=$ 0.009). Forest managers should consider landscape level effects, as well as forest stand composition, when recommending silvicultural treatments. 
This thesis dedicated to:

My daughter, Zelia Willow Kahler - that she may come to know that she can accomplish anything through perseverance and dedication. 


\section{Acknowledgements}

I thank the following agencies for supporting this project: United States Fish and Wildlife Service, United States Department of Agriculture Forest Service, Sandpiper Tecnologies, and the McIntire-Stennis Program. I especially thank Karen Stevens and the rest of the personnel at the Greenbrier Ranger District of the U. S. Forest Service for cooperation, help, and advice.

I also thank the Mountain Institute for providing welcoming shelter on inclement nights. I thank Jason Calhoun, Sheri Helon, Todd J. Polesiak, and Karen A. Sacilotto for their field assistance. I especially thank Athena L. Kahler, who worked at least as long and as hard on this project as I did.

Additionally, I thank each of my committee members for their contributions to this project. I thank James Anderson, my major professor, for providing me the opportunity to further my interests with guidance and patience. I thank William Thayne for sharing his statistical knowledge. Lastly, I thank Ray R. Hicks and James Rentch for sharing invaluable experiences and advice about the forests of West Virginia. 
TABLE OF CONTENTS:

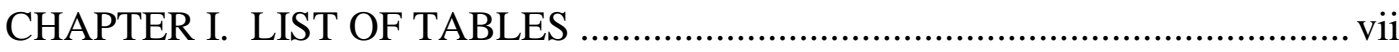

CHAPTER II. LIST OF TABLES ............................................................... viii

CHAPTER II. LIST OF FIGURES............................................................... ix

CHAPTER III. LIST OF TABLES ............................................................... $\mathrm{x}$

CHAPTER III. LIST OF FIGURES .........................................................

LIST OF APPENDICES ..........................................................................

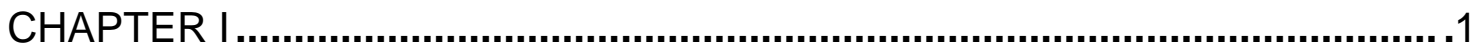

CAVITY-TREE RESOURCES AND HOLE-NESTING BIRDS OF SOUTHERN ALLEGHENY MOUNTAIN FORESTS ........................................................................... 1

FORESTS OF THE SOUTHERN ALLEGHENY MOUNTAINS REGION ........... 3

LIFE-HISTORY TRAITS OF AVIAN CAVITY-NESTERS ………………........... 6

FACTORS INFLUENCING NEST-SITE CHOICE …….................................... 11

Cavity-level Characteristics...................................................................... 11

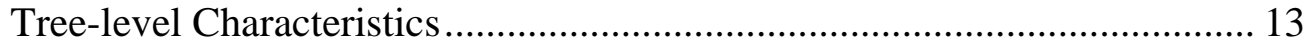

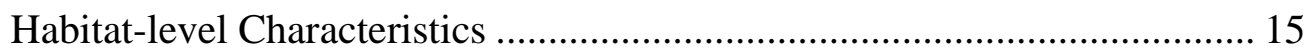

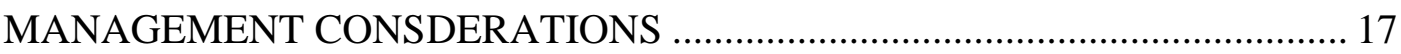

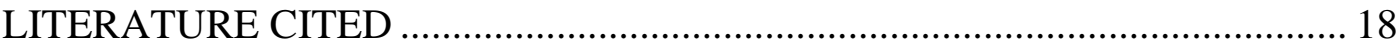

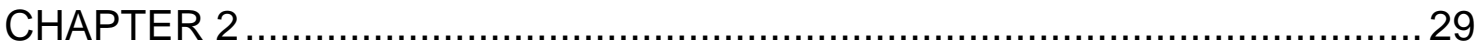

TREE CAVITY RESOURCES FOR DEPENDENT CAVITY-USING WILDLIFE

IN THE SOUTHERN ALLEGHENY MOUNTAINS ............................................... 29

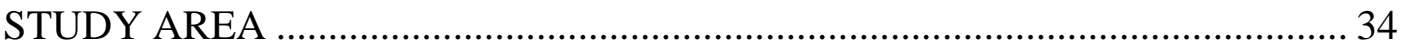

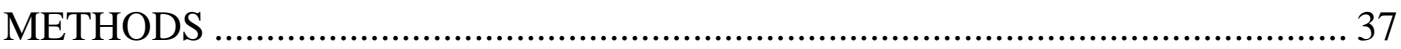

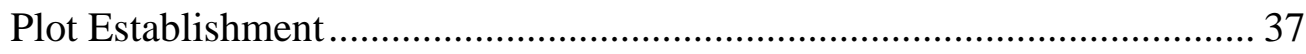

Plot Inventory and Cavity Search.............................................................. 38

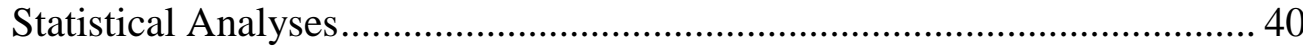

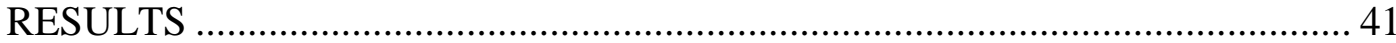

Cavity Occurrence Among Forest Cover Types .......................................... 42

Cavity Occurrence Among Tree Species ……………........................................... 43

Cavity Tree Characteristics ………………………..................................... 43

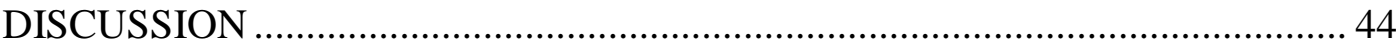

Cavity Tree Comparisons Among Forest Types ........................................... 44

Cavity Tree Comparisons Among Tree Species …………............................. 45

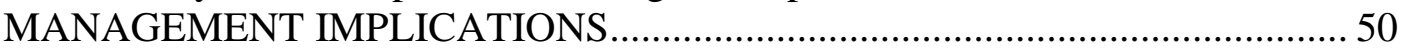

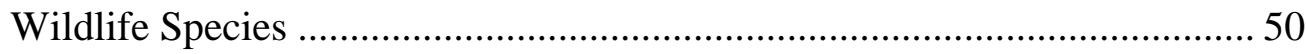

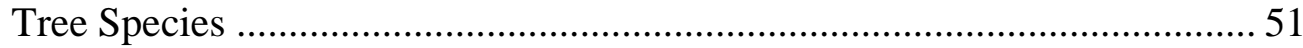

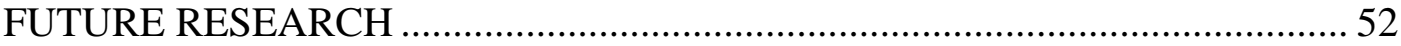

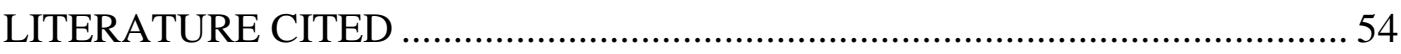

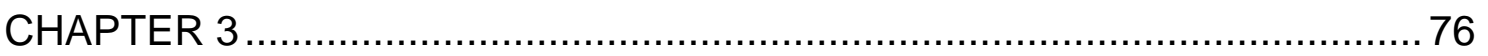




\section{FACTORS INFLUENCING AVIAN COMMUNITIES AMONG BOREAL, NORTHERN HARDWOOD, AND CENTRAL HARDWOOD FOREST COVER TYPES IN THE SOUTHERN ALLEGHENY MOUNTAINS .................................... 76}

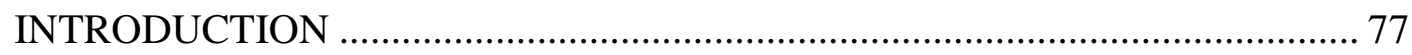

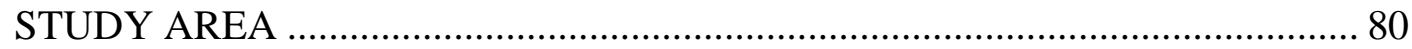

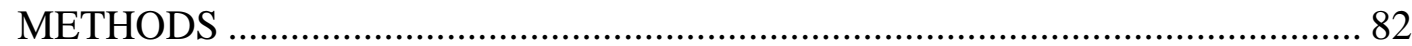

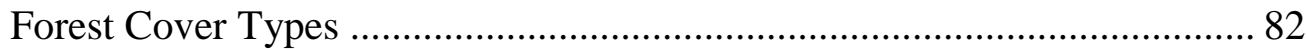

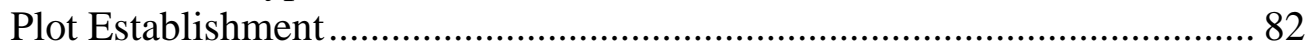

Plot Inventory and Cavity Search ...................................................... 83

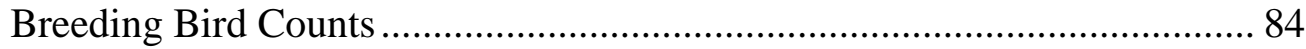

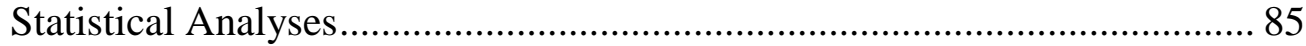

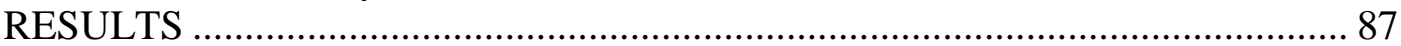

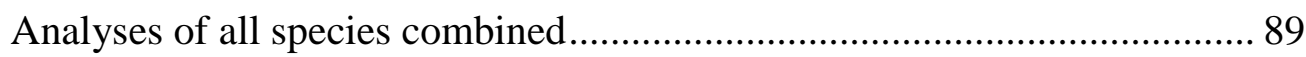

Analyses of Cavity-nesting Wildlife Species ........................................... 90

Relationships of cavity-using wildlife to cavity tree abundances ................ 92

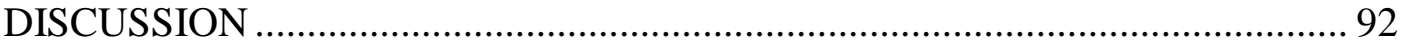

Wildlife species among forest cover types ............................................. 94

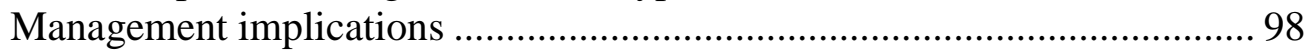

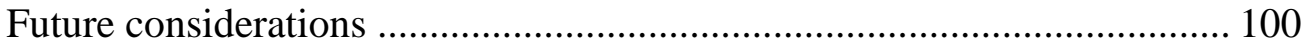

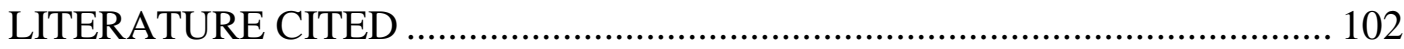




\section{CHAPTER 1. LIST OF TABLES}

Table 1. Cavity-nesting breeding birds of the southern Allegheny Mountains region of

West Virginia. ..........................................................28 


\section{CHAPTER 2. LIST OF TABLES}

Table 1. Decay class stages of standing tree stems (Maser et al. 1979)....

.62

Table 2. Comparisons of plot characteristics among forest cover types, Monongahela

National Forest, West Virginia, 1999-2001

Table 3. Log-likelihood comparisons of cavity occurrence among tree species occupying at least $3 \%$ of all cavity-tree stems or $3 \%$ of all plot inventory stems, Monongahela National Forest, 1999 - 2001 .64

Table 4. Comparisons between mean cavity tree and inventory tree diameters (DBH), paired by plot, Monongahela National Forest, West Virginia, 1999 - 2001.

Table 5. Comparisons between mean cavity tree height $(\mathrm{m})$ and inventory tree heights, paired by plot, Monongahela National Forest, West Virginia, 1999 - 2001. .66 


\section{CHAPTER 2. LIST OF FIGURES}

Figure 1. Plot locations in the Monongahela National Forest, West Virginia.

Figure 2. Percent of total basal area from prism tallies of RS - YB forest cover type, Monongahela National Forest, 1999 - 2001. .68

Figure 3. Percent of total stem counts from prism tallies of RS - YB forest cover type, Monongahela National Forest, 1999 - 2001.

Figure 4. Percent of total basal area from prism tallies of BC -M forest cover type,

Monongahela National Forest, 1999 - 2001.

Figure 5. Percent of total stem counts from prism tallies of $\mathrm{BC}-\mathrm{M}$ forest cover type, Monongahela National Forest, $1999-2001$.

Figure 6. Percent of total basal area from prism tallies of $\mathrm{WO}-\mathrm{BO}-\mathrm{NRO}$ forest cover

type, Monongahela National Forest, $1999-2001$.

Figure 7. Percent of total stem counts from prism tallies of $\mathrm{WO}-\mathrm{BO}-\mathrm{NRO}$ forest cover type, Monongahela National Forest, $1999-2001$.

Figure 8. Number of cavity trees showing excavated cavity trees by species among all

plots.

Figure 9. Number of cavity trees and non-cavity trees by species among all plots.......75 


\section{CHAPTER 3. LIST OF TABLES}

Table 1. Most common birds recorded in 50-meter point count plots in Monongahela

National Forest, West Virginia, 2000-2001.

Table 2. Mean species diversity, richness, and density values among forest cover types for years 2000 and 2001 data combined, Monongahela National Forest, West Virginia.

Table 3. Mean species diversity, richness, and density values among forest cover types

for year 2001 data alone, Monongahela National Forest, West Virginia. 


\section{CHAPTER 3. LIST OF FIGURES}

Figure 1. Breeding counts of most commonly occurring species within all 50-meter

radius plots, Monongahela National Forest, 2000-2001. 


\section{LIST OF APPENDICES}

Appendix I. UTM coordinates for all 90 plots; the first 75 were used in cavity tree

abundance analyses.

Appendix II. Mean basal area and stem counts per plot $(0.78 \mathrm{ha})$, Red spruce - yellow

birch cover type, Monongahela National Forest, West Virginia, 1999 - 2001.

Appendix III. Mean basal area and stem counts per plot ( 0.78 ha), Black cherry - maple

cover type, Monongahela National Forest, West Virginia, 1999 - 2001.

Appendix IV. Mean basal area and stem counts per plot (0.78 ha), White oak - black oak

- Northern red oak cover type, Monongahela National Forest, West Virginia, 1999 -

2001.

Appendix V. Percent of stems by damage class, of all inventory trees and all cavity trees, by species, Monongahela National Forest, West Virginia, 2000 - 2001.

Appendix VI. Percent of stems by decay class, of all inventory trees and all cavity trees,

by species, Monongahela National Forest, West Virginia, 2000 - 2001.

Appendix VII. Logistic regression models based on presence of bird species on 90 plots, Monongahela National Forest, West Virginia, 2000-2001.

Appendix VIII. Year 2000 individuals recorded in 50-meter point count plots in

Monongahela National Forest, West Virginia.

Appendix IX. Year 2001 individuals recorded in 50-meter point count plots in

Monongahela National Forest, West Virginia. 


\title{
CHAPTER 1
}

\section{CAVITY-TREE SELECTION AMONG HOLE-NESTING BIRDS, A REVIEW}

\begin{abstract}
Many challenges presently facing forest managers and ecologists stem from concerns, both real and imagined, that current forest management practices are oriented toward timber production and sales at the expense of wildlife habitat quality. One concern is that available nest-sites for cavity-nesting birds are reduced by intensive silviculture, thus negatively impacting avian reproductive efforts. Forests of the southern Allegheny Mountains of West Virginia are diverse in composition, mainly due to the topography of the region. Past forest management practices also have shaped the composition, structure, and size of forest patches within the region. Compared with other nesting strategies, cavity-use generally provides greater nesting success and decreased nest predation, yet adult longevity and fecundity rates vary among cavity-using strategies. Birds choose proper nesting sites based on cavity-, tree-, and habitat-level characteristics among forest stands. The importance of each characteristic varies with each nesting species. It is important to realize the habitat requirements of wildlife species when planning intensive forest management.
\end{abstract}

\section{INTRODUCTION}

Tree cavities have gained attention because the nest-site resource may be a

This thesis in the style of Southeastern Naturalist. 
limiting factor to some dependent hole-nesting bird populations (Johnson and Kermott 1994, von Haartman 1957). An array of mammals and herpetiles also use tree cavities as denning, nesting, or food-cache sites (DeGraaf and Shigo 1985, Hunter 1990, McComb and Noble 1981). Most tree cavities are in standing dead or declining trees (Thomas et al. 1979).

Most obligate North American cavity-nesters are in the orders Passeriformes (songbirds), Piciformes (woodpeckers), Apodiformes (swifts), Coraciiformes (kingfishers), Strigiformes (owls), Psittaciformes (parrots), Anseriformes (waterfowl), and Trogoniformes (trogons) (Johnsgard 2000, Newton 1994). In total, dependent holenesters, or those that nest only in tree cavities, comprise $4 \%$ of the North American avifauna (Newton 1994). Cavity-nesting may have evolved as a means of increasing reproductive success relative to open-nesting (Martin 1995).

The forested landscape of the southern Allegheny Mountains in West Virginia is distinctive due to the diversity and juxtaposition of forest cover types. Boreal (i.e., red spruce [Picea rubens]), northern hardwood, and central hardwood forest types are all found within close proximity of one another (Buckelew and Hall 1994, Eyre 1980). Interestingly, similarities in North American coniferous forest vegetative diversity have been shown to decrease with increasing distance between forest patches (Nekola and White 1999). Thus, separation distances from similar cover also may affect wildlife species associated with the insular vegetative cover.

Additionally, southern Allegheny Mountain forests differ markedly in composition and size from those of times prior to settlement by Europeans (Hicks 1998). Habitat requirements differ for each wildlife species, yet diversity and abundances of 
cavity-using wildlife may be suitable indicators of changes in forest stand conditions because of the close link between their reproductive success and the condition of forest resources (Carey 1983). For example, increases in snag (i.e., dead tree) densities generally correspond with increases in population densities, species richness and diversity of cavity-nesting birds (Zarnowitz and Manuwal 1985). Remnant snags (left after silvicultural treatment) provide suitable cavity sites for breeding birds (Ohmann et al. 1994). However, preservation of all cavity trees excessively reduce the total volume of harvestable timber (Goodwin and Balda 1983). Therefore, as is often the case, forests managers must strike a compromise when designating trees to leave or remove.

In view of the unique diversity of southern Allegheny Mountain forests, the purpose of this paper is to present the relationships between forest resources and avian cavity-nesting requirements. In particular, I review the advantages and costs of cavitynesting in comparison with other nesting strategies. I also review forest and tree characteristics that may influence nest-site choices of cavity-nesting birds so that managers may be better posed to address wildlife habitat needs. Because forested landscapes are ever-changing, I begin with an overview of the recent past history of southern Allegheny Mountain forests.

\section{FORESTS OF THE SOUTHERN ALLEGHENY MOUNTAINS REGION}

The physiographic Allegheny Mountain section of the Appalachian Plateau runs southwesterly from central Pennsylvania to the highest peaks of West Virginia and Highland and Bath Counties, Virginia (Fenneman 1938). The southern portion of the Allegheny Mountains is generally included in the central hardwood region, which 
contains $90 \%$ of the hardwood growing stock in the continental United States (Hicks 1998). More specifically, Braun (1950) regarded the southern Allegheny Mountains as part of the Mixed Mesophytic Forest Region of the central hardwoods, stressing the diversity of hardwood tree species found within the region. Because of these varying characteristics, the Allegheny Mountains contain vast, diverse, and unique forest lands.

The diversity of Allegheny Mountains forest types owes itself to the distinct topography of the area (Buckelew and Hall 1983, Hicks 1998). Slopes are steep, with reliefs mainly between 300 and $600 \mathrm{~m}$ (Hall 1983). At highest elevations, generally above $1000 \mathrm{~m}$, forest types have boreal characteristics (Buckelew and Hall 1994). Moving down in elevation, forests become a mosaic between higher, north-facing northern hardwood types and lower, south-facing central hardwood stands (Hicks 1998). In effect, the boreal and northern hardwood forest patches of the Allegheny Mountains (and Southern Appalachians), which are relicts from colder eras, are analogous to islands separated from a mainland forest cover type (Hall 1983). In fact, Hall (1983) analyzed breeding bird data among these forest regions and found similarities to the island biogeography ideas of MacArthur and Wilson (1967) (i.e., the number of species inhabiting an island is inversely proportional to the distance from mainland).

When pioneering settlers came to West Virginia, most found slopes too steep for farming, yet level forests were cleared to establish some farmsteads (Clarkson 1993). At higher elevations, red spruce tracts were girdled and burned to produce cattle pastures and later logged for timber (Clarkson 1993, Stephenson and Adams 1993); only 10\% of the original range of red spruce is now forested (Buckelew and Hall 1994). 
Removal of the timber has left mostly a mosaic of second- and third-growth forests (Stephenson 1993). Where red spruce forests were removed by logging, much has been replaced by second growth, northern hardwood species (Stephenson 1993). Preferential harvesting of black walnut (Juglans nigra), butternut (J. cinerea), and white oak (Quercus alba) has resulted in proportionately fewer of these trees in present-day forests (Carvell 1986). European introduced diseases and pests, such as chestnut blight (Endothia parasitica), beech bark disease, and the gypsy moth (Lymantria dispar), also have changed stand composition over time (Acciavatti et al. 1993, Showalter 2000). Trees weakened by leaf stripping, such as those ravaged by gypsy moths, are then subject to attack by boring insects and wood rot from fungi (Sander et al. 1981, Showalter 2000).

Since the 1960s, boreal forests of North America have shrunk in area, mainly due to increasing mortality rates of red spruce and balsam fir (Abies balsamea) at higher elevations (Stephenson and Adams 1993). Allegheny Mountain spruce forest patches display this trend, coupled with declining growth rates of spruce trees, possibly from acid rain deposition (Stephenson and Adams 1993). Not only are numerous bird species of the Allegheny Mountains limited in breeding to the boreal forests (Hall 1983), but the entire populations of the federally endangered Virginia northern flying squirrel (Glaucomys sabrinus fuscus) and Cheat Mountain Salamander (Plethodon nettingi) are within these relict spruce forest patches (Green and Pauley 1987, Odom et al. 2001). A notable ecological relationship exists between Virginia northern flying squirrels and various hypogeous fungi taxa that have mycorrhizal links with spruce trees (Mitchell 2001). During spring and fall months the squirrels rely on these fungi for food, and in 
turn are prime spore dispersers, thus contributing to the health of the spruce forests (Mitchell 2001).

Natural processes as well as management decisions are constantly changing forest cover composition and size. Undoubtedly, such changes continuously influence selection pressures that shape dependent wildlife population levels. Thus, knowledge of the lifehistory traits of cavity-nesting birds may supply a better understanding of the habitat characteristics required to maintain stable populations.

\section{LIFE-HISTORY TRAITS OF AVIAN CAVITY-NESTERS}

Generally, cavity-nesting birds may be divided into 2 groups: primary cavitynesters that excavate nest-holes (chiefly woodpeckers), and secondary-cavity nesters that use available holes (Table 1). Skeletal and muscular specializations allow woodpeckers to excavate sound wood (Kirby 1980). Yet, some songbirds that may nest in available holes, particularly of the Paridae (chickadees) and Sittidae (nuthatches), also may excavate nest-holes if wood of advanced decay is available (Martin and Eadie 1999, Scott et al. 1977). Still, some primary-nesters, such as the yellow-bellied sapsucker (Sphyrapicus varius), may use cavities excavated by other species or re-use cavities in successive breeding seasons (Scott et al. 1977).

Because selection pressures may differ markedly between primary and secondary cavity-nesting species, sources and degrees of nestling mortality and other life-history traits also may differ between primary and secondary cavity-nesting species (Martin and Li 1992). For these reasons forest managers may find it easier to consider cavity resources as part of an ecological nest web, similar to a food web (Martin and Eadie 
1999). A healthy nest web should include appropriate excavation trees for primarynesters, as well as an adequate number of available and suitable holes for secondarynesters.

To effectively provide nest sites for cavity-nesting birds, managers must understand why tree cavities are used. An examination of how life-history traits have evolved in cavity-nesting species in comparison to other species provides useful information on the suitability of tree cavities as nesting sites. The principle benefits of cavity-nesting in comparison to open nests include: lowered predation rates (Martin 1995, Nilsson 1986, von Haartman 1957); and increased protection from negative weather effects (i.e., deleterious temperature and precipitation levels) (Albano 1992; Slagsvold 1982, 1984). On the other hand, breeding success of cavity-nesters is limited by: increased parasite loads (Moller et al. 1990); inadequate cavity space (Slagsvold and Amundsen 1992, Stewart and Robertson 1999); and ill-suited microclimates within cavities (Wiebe 2001). In turn, all costs incurred by cavity nesting may increase as limitations to the nest web increase.

Early studies established the paradigm that hole-nesting species have greater nesting success than birds with open nests (Lack 1954, Nice 1957), particularly because cavity-nesters incur lower predation rates compared to open-nesters (Martin 1995, von Haartman 1957). Of North American cavity-nesting birds, woodpeckers have the highest rate of nest success (77\%), followed by other primary species (i.e., weak - excavators) (66\%), and secondary-users (54\%) (Johnson and Kermott 1994). Martin (1995) analyzed the relationship between nest success, nest predation, and nest type (not using nest boxes) and determined primary excavators, followed by secondary cavity-nesters, have the 
highest nest success and lowest predation rates of the 2 cavity-nest and 3 open-nest types studied. However, most early studies of nest predation were conducted on nest boxes, where predation rates may be lower than in natural cavities (Nilsson 1984, 1986). Indeed, when natural cavities were studied instead of boxes, Nilsson (1986) found the fledgling rate for 6 European secondary hole-nesters to be approximately equal that of open-nesters.

One notable nest-site characteristic that affects the nest success of secondary cavity-nesters more than primary cavity-nesters is the soundness of the surrounding wood (Albano 1992, Christman and Dhondt 1997). For example, Albano (1992) discovered that nests of Carolina chickadees (Poecile carolinensis) in softer wood were more likely to be depredated; in fact $78.7 \%$ of nest mortality was attributed to nest predation. Similarly, differences in wood soundness have been found between successful and depredated black-capped chickadee ( $P$. atricapilla) nests; successful nests had significantly thicker walls and harder surrounding wood (Christman and Dhondt 1997).

In turn, other life-history traits are affected by nest-site characteristics (Martin 1995). For example, nest-site attributes and nest predation together explained over half $(51.1 \%)$ of the variation in clutch sizes among 83 species of open-nesting (i.e., ground, shrub, and canopy) and cavity-nesting (i.e., primary and secondary) Passeriformes and Piciformes (Martin 1995). Adult survival, annual fecundity, broods per year, and clutch size also varies predictably with nest-site qualities (Martin 1995). Secondary-nesters were consistent outliers in nest predation relationships relative to other nest-site types, having larger clutch sizes and higher annual fecundity given their nest predation rates (Martin 1995). 
Traditionally, food-limitation hypotheses have been widely accepted as accounting for the evolution of avian clutch sizes (Lack 1954). However, nest predation also had been suggested as the primary evolutionary determinant of avian clutch sizes (Skutch 1949). Naturally, females would lay a clutch size that maximizes their own individual recruitment (Pettifor et al. 1988), and clutch size is often smaller at nest sites with greater predation risks (Martin 1988).

Nur (1984) demonstrated that when brood sizes are artificially increased, parents actively choose not to maintain per capita feeding effort to maximize reproductive fitness. Lima (1987) developed a cost-benefit model in which females (of open- and cavity-nesting species) are able to control clutch size, foraging effort, and therefore nestling mass. The model indicated that clutch size may be food-influenced rather than food limited, and nest predation alone may be adequate to explain an existence of an optimal clutch size.

Although nest predation may be the driving force determining avian clutch sizes, other factors may influence clutch size in hole-nesting birds as well. For example, cavity size may affect clutch sizes laid by cavity-nesting birds (Stewart and Robertson 1999). Optimal clutch size may equate to the maximum number of nestlings that can fit in a nest cavity with the least cost to reproduction (Stewart and Robertson 1999). Indeed, clutch size is positively correlated with cavity size in several secondary-nesting species (Karlsson and Nilsson 1977, Rendell and Robertson 1993). By manipulating clutch sizes of tree swallows (Tachycineta bicolor) nesting in boxes of various sizes to the mode clutch size of 6 eggs, Stewart and Robertson (1999) determined that females may actively control clutch sizes to maximize their reproductive fitness. The effects of overcrowding 
most logically explained growth differences between hatchlings in small and large nest boxes, which in turn translates into differences in reproductive fitness for the parents.

A third possible influence on clutch size of secondary cavity-nesters is nest-site availability (Martin an Li 1992). That secondary cavity-nesters have relatively larger clutch sizes and higher fecundity rates, given their predation rates (relative to other nestsite types), suggests that nest predation actually contributes little to secondary cavitynesting species clutch sizes (Martin 1995). However, if nest sites are a limiting factor, then increased reproductive effort through increased clutch size are favored when suitable nest sites are obtained (Martin 1993).

In sum, life-history traits vary accordingly with nesting strategies. Primary cavity-nesting species, for example, usually have larger clutch sizes and greater nest success than other species, yet the cost is increased parental investment and lower reproduction rates. Accordingly, adult longevity is greater for primary cavity nesters. In contrast, secondary cavity-nesters invest relatively more energy in more broods/yr than other species, so reproduction rate is relatively high and adult longevity is relatively low. However, because nest-site quality varies among secondary cavity-nesting species, nestsuccess is relatively lower than primary-nesting species due to increased predation risks. Furthermore, Martin (1995) lumped weak excavating cavity-nesting species in with nonexcavating species. Unquestionably, model results (relating nest strategies to life-history traits) were affected because weak excavating species have different selection pressures than true secondary cavity-nesters. Nonetheless, life-history traits undoubtedly drive nest-site choices in cavity-nesting birds. 


\section{FACTORS INFLUENCING NEST-SITE CHOICE}

Interference competition, incorrect nest temperatures, and nest parasites are some examples of factors that negatively influence breeding success (Nilsson 1986). Predation also negatively affect breeding success (Albano 1992). Forest management practices influence these factors, and thus impact breeding success of cavity nesting birds. Holenesters increase success by choosing cavities that lessen negative impacts on breeding, and visual characteristics of forests and trees cue birds to suitable nesting sites. Characteristics affecting cavity use occur at the cavity-, tree-, or habitat- level (Sedgwick and Knopf 1990). Because selection pressures are similar for species with identical nesting strategies, I do not limit examples to birds of the southern Allegheny Mountains.

\section{Cavity-level Characteristics}

Although the characteristics of individual trees may not be as indicative of wildlife use as forest stand characteristics, they are nonetheless important. For example, most birds tend to choose trees with little bark coverage (Land et al. 1989, Swallow et al. 1986). Likewise, primary cavity nesters appear limited by the hardness of some trees, which also will affect the numbers of secondary-nesting birds (Schepps 1999). Diversity and species richness tend to increase as the average snag height and amount of bark decrease, which is related to the advanced state of decay (Land et al. 1989). Some other indicators of wildlife use of cavity trees include fruiting bodies of heartwood decay fungi, branch stubs, and broken tops (Runde and Capen 1987).

Primary-nesting bird species choose cavities based on their structural quality (Harris 1983; McNair 1984). Cavity shapes formed by pileated woodpeckers (Drycopus 
pileatus) followed decay patterns in the snag heartwood; the shape and soundness of surrounding wood determines usability as nest-sites (Harris 1983). Short (1979) suggests this behavior evolved as protection against cavity usurpation by larger or more aggressive cavity-users that would have to excavate harder wood to expand holes. This also is true of brown-headed nuthatches (Sitta pusilla), which in addition will plug crevices (in cavities) with bark shreds to make them usable (McNair 1984).

Secondary cavity-nesters reoccupy holes more frequently than primary cavitynesters (Sedgwick 1997). Conner et al. (1998) suggested that male red-cockaded woodpeckers (Picoides borealis) select the newest cavities for nest sites due to increased ectoparasites in older cavities. Larval forms of Calliphorid flies (Protocalliphora spp.) found in some nest holes feed on the blood of nestling birds, decreasing fitness of the host birds (Whitworth and Bennet 1992). Additionally, many of the Protocalliphora are host specific (Bennet and Whitworth 1992), thus rendering otherwise suitable holes as deficient to some species. In response, male house wrens (Troglodytes aedon) remove old nesting material, increasing reproductive success by decreasing ectoparasite loads (Pacejka et al. 1998).

In southwest Virginia, Conner (1975) found significantly more woodpecker excavations leeward of prevailing winds to ameliorate negative microclimate effects. Similarly, northern spotted owls (Strix occidentalis caurina) on the Olympic Peninsula, Washington, occupy cavities oriented east-northeast, in avoidance of prevailing southwesterly storms (Forsman and Giese 1997). In contrast, excavations of northern flickers (Colaptes auratus) nest holes in British Columbia were biased toward the 
increased warmth of the south (Wiebe 2001). Thus, climatic effects influence nest-site choice in cavity-using species.

\section{Tree-level Characteristics}

Runde and Capen (1987) found that yellow-bellied sapsuckers (Sphyrapicus varius) prefer nesting in quaking aspen (Populus tremuloides) with hard outer wood and older excavations. Kilham (1971) suggested that yellow-bellied sapsuckers seeking cavity sites have a search image of trees bearing false tinder (Fomes igniarius var. populinus) conks. Mature aspen, as well as butternut and American beech (Fagus grandifolia), bear such conks, which indicate soft heartwood inside harder, insulatory wood. Likewise, false tinder conks infected over $50 \%$ of cavity trees in Colorado montane aspen stands, which are out of yellow-bellied sapsucker range (Winternitz and Cahn 1983).

However, tree hardness is not necessarily related to external features such as number of conks or amount of bark present (Schepps et al. 1999). Weaker primary-users, such as the nuthatches, are more limited by soft wood availability than by abundance of large trees (Steeger and Hitchcock 1998). Black-capped chickadees also are weak excavators and prefer soft outer wood (Runde and Capen 1987).

Excavation ability or strength is related to the morphology of the species (Kirby 1980, Schepps et al. 1999). However, in assessing hardness of trees used by red-naped sapsuckers (Sphyrapicus nuchalis), Williamson's sapsucker (S. thyroideus), hairy woodpeckers (Picoides villosus), and downy woodpeckers (P. pubescens), Schepps et al. (1999) found bird morphology an incorrect indicator of nest-tree usage. Sapsuckers are 
assumed to be weaker than Picoides woodpeckers, yet red-naped sapsuckers nested in the hardest trees and downy woodpeckers chose the softest trees.

Damage to trees, such as bole injuries or broken tops, are indicators of possible chickadee and nuthatch nest trees (Runde and Capen 1987, Steeger and Hitchcock 1998). Tree damage can indicate to bird species wood softness due to disease, as red-breasted nuthatches (Sitta canadensis) preferentially use Douglas-firs infested with root disease (Armillaria ostoyae), stemwood decay, or mountain pine beetle infestation (Dendroctonus ponderosae) (Steeger and Hitchcock 1998).

Density of dead limbs, limb length, and tree diameter at $1.37 \mathrm{~m}(4.5 \mathrm{ft})(\mathrm{DBH})$ may drive nest-site choice among trees of preferred species (Sedgwick and Knopf 1990). One example of limb importance is that during incubation a male house wren will sing from a branch nearby the nest hole, possibly acting as sentinels for the nesting female (Ziolkowksi et al. 1997). Some species, such as gilded flickers (Colaptes chrysoides), may prefer holes with unobstructed surveillance for potential predation (Zwartjes and Nordell 1998).

The general quality of the site also is important. The density and diversity of cavity nesting birds decreases with increasing understory thickness, possibly due to limited access to the snags (Brawn 1988, Land et al. 1989). At the same time, there must be enough understory vegetation at the nest site to provide protection from predators (Pogue and Schnell 1994, Rodewald and Smith 1998). Cavity nesting birds seem benefit most from small stands that are surrounded by a variety of forested land (Land et al. 1989). Trees that produce mast, such as American beech, should be managed as a food producer, even if they do not provide suitable cavities (McComb and Muller 1983). 
Grubb and Bronson (1995) found that black-capped and Carolina chickadees use small diameter trees with hard surfaces, decreasing competition from larger nesters and reducing depredation. However, Runde and Capen (1987) found that black-capped chickadees prefer soft outer wood for excavation, and bark cover is not related to nestsite choice. In a southern Illinois study of Carolina chickadees, $78.7 \%$ of all egg and chick mortality was attributed to predation; nest-site selection plasticity and rapid renesting ability compensated for recruitment losses (Albano 1992). Albano (1992) found an inverse correlation between height above ground of chickadee nests and nest predation rates. In contrast, Hay and Guntert (1983) suggest that pygmy nuthatches select smaller and lower cavities to lessen convective heat loss from wind.

\section{Habitat-level Characteristics}

Red-headed woodpeckers prefer nesting in areas of high snag density, suggesting they require snags for foraging as well as roosting (Sedgwick and Knopf 1990). Ninetysix percent of variations in cavity-nesting bird density and diversity in slash pine (Pinus elliottii) plantations was explained by regressions on various stand and snag characteristics (Land et al. 1989). Snag clusters in the plantations were important indicators of where bird cavity nests were likely to occur.

In Kentucky, McComb and Muller (1983) determined black locust (Robinia pseudoacacia), flowering dogwood (Cornus florida), and sassafras (Sassafras albidum) were most prone to snag formation. Snag densities $\geq 10 \mathrm{~cm} \mathrm{DBH}$ were greatest in stands dominated by chestnut oak (Quercus prinus) and red maple (Acer rubrum), yet red maple, American beech, and red oaks (Quercus spp.) showed reduced snag formation 
(McComb and Muller 1983). Xeric areas exhibited higher snag densities than mesic sites (McComb and Muller 1983).

In general, when nest-site opportunities are more abundant woodpeckers nest more closely to one another than when nesting opportunities are scant, suggesting that quality nest-sites are a limiting factor directing habitat use (Short 1979). Similarly, black-capped chickadees and tufted titmice (Baeolophus bicolor) nesting near house wrens risk having nests, eggs, and nestlings destroyed (White and Kennedy 1997). White and Kennedy (1997) concluded nests in interior forest locations were less likely to be visited by house wrens than nests along forest edges.

Sedgwick and Knopf (1990) determined overstory decadence (measured by cavity density, snag density, total dead-limb length, and limb tree density) has a significant indicator of preferential nesting habitat to several cavity-nesting bird species in cottonwood floodplains. However, measures of basal area, canopy cover, density of medium-sized trees, openness, and distance to forest edge did not differ between bird nesting sites and random sites in the same area.

Swallow et al. (1986) concluded that overall forest-site characteristics influence primary-nesting bird uses as much as snag characteristics. Forest characteristics sampled included: type (i.e., second-growth or mature); species diversity and densities for tree, shrub, and herbaceous species; species diversity, density and basal area of snags; and average canopy closure. Snag characteristics included DBH, species, height, amount of remaining bark, twig or limb loss, fungal decomposition, and vine coverage. Also, a Missouri study of pileated woodpecker habitat indicated area covered by pole timber (15 - $25 \mathrm{~cm} \mathrm{DBH)} \mathrm{was} \mathrm{negatively} \mathrm{related} \mathrm{to} \mathrm{bird} \mathrm{abundance} \mathrm{(Renken} \mathrm{and} \mathrm{Wiggers} \mathrm{1993).}$ 


\section{MANAGEMENT CONSIDERATIONS}

Because the forested landscape is not static, managers must be able to predict that outcomes of current management decisions will meet long-term, multiple-use goals. For example, forest fragmentation is recognized as a major negative impact on wildlife populations (Hagan et al. 1996). However, insular fragmentation effects that affect the biodiversity of southern Allegheny Mountain forests may result from natural phenomena. The natural processes and relationships of wildlife among various forest cover types should be analyzed and monitored on relatively unmanaged landscapes. Consequentially, the true outcomes of management decisions can be assessed with more accuracy.

Furthermore, wildlife density is not necessarily a good indicator of habitat quality (Vickery et al. 1992). In some cases, forest stands with greater wildlife population densities may have lower reproduction rates than forest stands with fewer individuals (Hagan et al., 1995). Reproduction rates for birds are most easily measured through nest surveys. Therefore, it is important to recognize suitable nesting sites for cavity-nesting birds for at least 3 reasons: (1) to predict or infer productivity rates based on nest-site quantities and quality, (2) to aid in nest searches for productivity monitoring (3) to judge impacts of current or proposed silvicultural activities on cavity-nesting species.

Sound forestry practices can include management for quality timber as well as for cavity-nesting birds. Generally, cavity trees are not likely to produce quality timber, yet many may be used multiple times by several animals (Carey 1983). However, because growing space is limited, compromises must be made when managing for wildlife and quality timber production. Thus, it is important to know which trees are most likely to harbor usable cavities so that management objectives can be maximized. 


\section{LITERATURE CITED}

Acciavatti, R. E., T. J. Allen, A. R. Miller, L. L. Pechuman, B. C. Kondratieff, R. F. Kirchner, A. G. Wheeler, Jr., S. M. Clark, E. van den Berghe, and W. J. Arnold. 1993. Pages 143-178. In Stephenson, S. L., (ed.). Upland Forests of West Virginia. McClain Printing Co., Parsons, WV.

Albano, D. J. 1992. Nesting mortality of Carolina chickadees breeding in natural cavities. Condor 94:371-382.

Bennet, G. F., and T. L. Whitworth. 1992. Host, nest, and ecological relationships of species of Protocalliphora (Diptera: Calliphoridae). Canadian Journal of Zoology 70:51-61.

Braun, E. L. 1950. Deciduous Forests of Eastern North America. The Blakiston Co., Philadelphia, PA.

Brawn, J. D. 1988. Selectivity and ecological consequences of cavity nesters using natural vs. artificial sites. Auk 105:789-91.

Broberg, L. E. 1999. Will management of vulnerable species protect biodiversity? Journal of Forestry 97:12-18.

Buckelew, A. R., Jr., and G. A. Hall. 1994. The West Virginia breeding bird atlas. University of Pittsburgh Press, Pittsburgh, PA.

Carey, A. B. 1983. Monitoring diurnal, cavity-using bird populations. Pages 188-199 In Davis, J. W., G. A. Goodwin, and R. A. Ockenfels, (tech. coords.). Snag habitat management: Proceedings of the symposium. U.S. Forest Service, General Technical Report RM-99. 
Carey, A. B., and R. O. Curtis. 1996. Conservation of biodiversity: a useful paradigm for forest ecosystem management. Wildlife Society Bulletin 24:610-620.

Carvell, K. L. 1986. Effect of past history on present stand composition and condition. Pages 1-7. In Smith, H. C., and M. C. Eye, (eds.). Guidelines for managing immature Appalachian hardwood stands. West Virginia University Books, Morgantown, West Virginia.

Christman, B. J., and A. A. Dhondt. 1997. Nest predation in black-capped chickadees: How safe are cavity nests? Auk 114:769-773

Clarkson, R. B. 1993. Destruction of the upland forests by lumbering and fire. Pages 35-65 In Stephenson, S. L., (ed.). Upland Forests of West Virginia. McClain Printing Co., Parsons, WV.

Conner, R. N. 1975. Orientation of entrances to woodpecker nest cavities. Auk 92:371374.

, D. Saenz, D. C. Rudolph, W. G. Ross, and D. L. Kulhavy. 1998. Red-cockaded woodpecker nest-cavity selection: Relationship with cavity age and resin production. Auk 115:447-454.

DeGraaf, R. M., and A. L. Shigo. 1985. Managing cavity trees for wildlife in the Northeast. USDA Forest Service General Technical Report NE-101. 23pp.

DeMaynadier, P. G., and M. L. Hunter, Jr. 1995. The relationship between forest management and amphibian ecology: a review of the North American literature. Environmental Reviews 3:230-261.

Eyre, F. H. 1980. Forest cover types of the United States and Canada. Society of American Foresters, Washington, DC, USA. 
Fenneman, N. M. 1938. Physiography of Eastern United States. McGraw-Hill Book Co., New York City, NY, USA.

Forsman, F. D., and A. R. Giese. 1997. Nests of northern spotted owls on the Olympic Peninsula, Washington. Wilson Bulletin 109:28-41.

Goodwin, G. A., and R. P. Balda. 1983. Challenges of snag management. Pages 223226 In Davis, J. W., G. A. Goodwin, and R. A. Ockenfels, (tech. coords.). Snag habitat management: Proceedings of the symposium. U.S. Forest Service, General Technical Report RM-99.

Green, N. B., and T. K. Pauley. 1987. Amphibians and Reptiles of West Virginia. University of Pittsburgh Press, Pittsburgh, PA. 241 pp.

Hagan, J. M., W. M. Vander Haegen, and P. S. McKinley. 1996. The early development of forest fragmentation effects on birds. Conservation Biology 10:188-202.

Hagan, J. M., and S. L. Grove. 1999. Coarse Woody Debris. Journal of Forestry 97:611.

Hall, G. A. 1983. West Virginia Birds. Carnegie Museum of Natural History Special Publication No. 7, Pittsburgh, PA. 180 pp.

Harris, R. D. 1983. Decay characteristics of pileated woodpecker nest trees. Pages 125129 In Davis, J. W., G. A. Goodwin, and R. A. Ockenfels, (tech. coords.). Snag habitat management: Proceedings of the symposium. U.S. Forest Service, General Technical Report RM-99.

Harrison, H. H. 1975. Birds' nests. Houghton Mifflin Company, New York, NY. 257 pp. 
Hay, D. B., and M. Guntert. 1983. Seasonal selection of tree cavities by pygmy nuthatches based on cavity characteristics. Pages 117-124 In Davis, J. W., G. A. Goodwin, and R. A. Ockenfels, (tech. coords.). Snag habitat management: Proceedings of the symposium. U.S. Forest Service, General Technical Report RM-99.

Hicks, R. R., Jr. 1998. Ecology and Management of central hardwood forests. John Wiley \& Sons, New York, NY.

Hunter, M. L. 1990. Dying, dead, and down trees. Pages 157-180 In Wildlife, forests, and forestry: principles of managing forests for biological diversity. Prentice Hall, Englewood Cliffs, NJ.

Johnsgard, P. A. 2000. Trogons and quetzals of the world. Smithsonian Institution Press, Washington, DC, USA.

Johnson, L. S., and L. H. Kermott. 1994. Nesting success of cavity-nesting birds natural tree cavities. Journal of Field Ornithology 65:36-51.

Karlsson, J. and S. G. Nilsson. 1977. The influence of nest-box area on clutch size in some hole-nesting passerines. Ibis 119:207-211.

Kilham, L. 1971. Reproductive behavior of yellow-bellied sapsuckers I. Preference for nesting in Fomes-infected aspens and nest hole interrelations with flying squirrels, raccoons, and other animals. Wilson Bulletin 83:159-171.

Kirby, V. C. 1980. An adaptive modification in the ribs of woodpeckers and piculets (Picidae). Auk 97:521-532.

Lack, D. 1954. The natural regulation of animal numbers. Clarendon Press, Oxford, UK. 
Land, D., W. R. Marion, and T. E. O’Meara. 1989. Snag availability and cavity nesting birds in slash pine plantations. Journal of Wildlife Management 53:1165-1171.

Lima, S. L. 1987. Clutch size in birds: A predation perspective. Ecology 68:1062-1070.

MacArthur, R. H., and E. O. Wilson. 1967. The theory of island biogeography. Princeton University Press, Princeton, NJ.

Martin, K., and J. M. Eadie. 1999. Nest webs: A community-wide approach to the management and conservation of cavity-nesting forest birds. Forest Ecology and Management 115:243-257.

Martin, T. E. 1988. Habitat and area effects on forest bird assemblages: is nest predation an influence? Ecology 69:74-84.

Martin, T. E. 1993. Evolutionary determinants of clutch size in cavity-nesting birds: Nest predation or limited breeding opportunities? American Naturalist 142:937946.

. 1995. Avian life history evolution in relation to nest sites, nest predation, and food. Ecological Monographs 65:101-127. , and P. Li. 1992. Life history traits of open versus cavity-nesting birds. Ecology 73:579-592.

McComb, W. C., and R. N. Muller. 1983. Snag densities in old-growth and secondgrowth Appalachian forests. Journal of Wildlife Management 47:376-382. ,W. C., and R. E. Noble. 1981. Herpetofaunal use of natural tree cavities and nest boxes. Wildlife Society Bulletin 9:261-267.

McNair, D. B. Clutch-size and nest placement in the brown-headed nuthatch. Wilson Bulletin 96:296-301. 
Moller, A. P., K. Allander, and R. Dufva. 1990. Fitness effects of parasites on passerine birds: A review. Pages 269-280 In J. Blondel, A. Gosler, J. -D. Lebreton, and R. McCleery, (eds.). Population biology of passerine birds. Springer-Verlag, New York, NY.

Mitchell, D. 2001. Spring and fall diet of the endangered West Virginia northern flying squirrel (Glaucomys sabrinus fuscus). American Midland Naturalist 146:439443.

Nekola, J. C., and P. S. White. 1999. The distance decay of similarity in biogeography and ecology. Journal of Biogeography 26:867-878.

Newton, I. 1994. The role of nest sites in limiting the numbers of hole-nesting birds: A review. Biological Conservation 70:265-276.

Nice, M. M. 1957. Nesting success in altricial birds. Auk 74:305-321.

Nilsson, S. G. 1984. The evolution of nest-site selection among hole-nesting birds: the importance of nest predation and competition. Ornis Scandinavica 15:167-175.

Nilsson, S. G. 1986. Evolution of hole-nesting in birds: on balancing selection pressures. Auk 103:432-435.

Nur, N. 1984. The consequences of brood size for breeding blue tits II. Nestling weight, offspring survival and optimal brood size. Journal of Animal Ecology 53:497517.

Odom, R. H., W. M. Ford, J. W. Edwards, C. W. Stihler, and J. M. Menzel. 2001. Developing a habitat model for the endangered Virginia northern flying squirrel (Glaucomys sabrinus fuscus) in the Allegheny Mountains of West Virginia. Biological Conservation 99:245-252. 
Ohmann, J. L., W. C. McComb, and A. A. Zumrawi. 1994. Snag abundance for primary cavity-nesting birds on nonfederal forest lands in Oregon and Washington. Wildlife Society Bulletin 22:607-620.

Onal, H. 1997. Trade-off between structural diversity and economic objectives in forest management. American Journal of Agricultural Economics 79:1001-1012.

Pacejka, A. J., C. M. Gratton, and C. F. Thompson. 1998. Do potentially virulent mites affect house wren (Troglodytes aedon) reproductive success? Ecology 79:17971806.

Pettifor, R. A., C. M. Perrins, amd R. H. McCleery. 1988. Individual optimization of clutch size in great tits. Nature 336:360-362.

Pogue, D. W., and G. D. Schnell. 1994. Habitat characterization of secondary cavitynesting birds in Oklahoma. Wilson Bulletin 106:203-26.

Rendell, W. B., and R. J. Robertson. 1993. Cavity size, clutch size and the breeding ecology of tree swallows Tachycineta bicolor. Ibis 135:305-310.

Renken, R. B., and E. P. Wiggers. 1993. Habitat characteristics related to pileated woodpecker densities in Missouri. Wilson Bulletin 105:77-83.

Rodewald, P.G., and K. G. Smith. 1998. Short-term effects of understory and overstory management on breeding birds in Arkansas oak-hickory forests. Journal of Wildlife Management 62:1411-1417.

Runde, D. E., and D. E. Capen. 1987. Characteristics of northern hardwood trees used by cavity-nesting birds. Journal of Wildlife Management 51:217-223. 
Sander, I. L., C. Merritt, and E. H. Tryon. 1981. Oak-hickory. Pages 23-29 In Choices in silviculture for American forests. Society of American Foresters, Washington, DC.

Schepps, J., S. Lohr, and T. E. Martin. 1999. Does tree hardness influence nest-tree selection by primary cavity nesters? Auk 116:658-665.

Sedgwick, J. A., and F. L. Knopf. 1990. Habitat relationships and nest site characteristics of cavity-nesting birds in cottonwood floodplains. Journal of Wildlife Management 54:112-124.

, J. A. 1997. Sequential cavity use in a cottonwood bottomland. Condor 99:880887.

Short, L. L. 1979. Burdens of the Picid Hole-excavating habit. Wilson Bulletin 91:1628.

Showalter, C. R. 2000. The relationships between snags and cavity-nesting birds in a gypsy moth impacted forest. Thesis, West Virginia University, Morgantown, WV.

Skutch, A. F. 1949. Do tropical birds rear as many young as they can nourish? Ibis $91: 430-455$.

Steeger, C., and C. L. Hitchcock. 1998. Influence of structure and diseases on nest-site selection by red-breasted nuthatches. Journal of Wildlife Management 62:134958.

Stephenson, S. L. 1993. Upland forest vegetation. Pages 11-34 In Stephenson, S. L., (ed.). Upland Forests of West Virginia. McClain Printing Co., Parsons, WV. 
, and H. S. Adams. 1993. Threats to the Upland Forests. Pages 261-273 In

Stephenson, S. L., (ed.). Upland Forests of West Virginia. McClain Printing Co., Parsons, WV.

Stewart, L. M. Stewart, R. J. Robertson. 1999. The role of cavity size in the evolution of clutch size in tree swallows. Auk 116:553-556.

Swallow, S.K., R. J. Gutierrez, and R. A. Howard, Jr. 1986. Primary cavity-site selection by birds. Journal of Wildlife Management 50:576-583.

Thomas, J. W., R. G. Anderson, C. Maser, and E. L. Bull. 1979. Snags. Pages 60-67 In J. W. Thomas, editor. Wildlife habitats in managed forests - the Blue Mountains of Oregon and Washington. U. S. Forest Service Agricultural Handbook 553. US. Government Printing Office, Washington, DC.

Vickery, P. D., M. L. Hunter, Jr., and J. V. Wells. 1992. Is density an indicator of breeding success? Auk 109:706-710.

von Haartman, L. 1957. Adaptation in hole-nesting birds. Evolution 11:339-347. White, D. W., and E. D. Kennedy. 1997. Effect of egg covering and habitat on nest destruction by house wrens. Condor 99:873-879.

Whitworth, T. L., and G. F. Bennet. 1992. Pathogenecity of larval Protocalliphora (Diptera: Calliphoridae) parasitizing nestling birds. Canadian Journal of Zoology 70:2184-2191.

Wiebe, K. L. 2001. Microclimate of tree cavity nests: is it important for reproductive success in northern flickers? Auk 118:412-421.

Winternitz, B. L., and H. Cahn. 1983. Nestholes in live and dead aspen. Pages 102-106 In Davis, J. W., G. A. Goodwin, and R. A. Ockenfels, (technical coords.). Snag 
habitat management: Proceedings of the symposium. U.S. Forest Service, General Technical Report RM-99.

Zarnowitz, J. E., and D. A. Manuwal. 1985. The effects of forest management on cavitynesting birds in northwestern Washington. Journal of Wildlife Management 49:255-63.

Zwartjes, P. W., and S. E. Nordell. 1998. Patterns of cavity-entrance orientation by gilded flickers (Colaptes chrysoides) in cardon cactus. Auk 115:119-126 
Table 1. Cavity-nesting breeding birds of the southern Allegheny Mountains region of West Virginia.

\begin{tabular}{|c|c|c|c|}
\hline Common name & Scientific name & Cavity use $^{\mathrm{a}}$ & General cover associations ${ }^{b}$ \\
\hline wood duck & Aix sponsa & obligate, secondary & wooded wetlands \\
\hline hooded merganser & Lophodytes cucullatus & facultative, secondary & wooded wetlands \\
\hline American kestrel & Falco sparverius & facultative, secondary & open areas, farmlands \\
\hline barn owl & Tyto alba & facultative, secondary & semi-wooded areas \\
\hline Eastern screech-owl & Otus asio & facultative, secondary & wooded areas \\
\hline great horned owl & Bubo virginianus & facultative, secondary & mature deciduous forest \\
\hline barred owl & Strix varia & facultative, secondary & mature mixed forests \\
\hline Northern saw-whet owl & Aegolius acadicus & obligate, secondary & spruce or mixed forests \\
\hline red-headed woodpecker & Melanerpes erythrocephalus & obligate, primary & open oak groves \\
\hline red-bellied woodpecker & Melanerpes carolinus & obligate, primary & central hardwoods \\
\hline yellow-bellied sapsucker & Sphyrapicus varius & obligate, primary & wooded, upper elevations \\
\hline downy woodpecker & Picoides pubescens & obligate, primary & mixed forests \\
\hline hairy woodpecker & Picoides villosus & obligate, primary & spruce or mixed forests \\
\hline Northern flicker & Colaptes auratus & obligate, primary & semi-wooded areas \\
\hline pileated woodpecker & Dryocopus pileatus & obligate, primary & mixed hardwoods \\
\hline great-crested flycatcher & Myiarchus crinitus & obligate, secondary & mature central hardwoods \\
\hline tree swallow & Tachycineta bicolor & obligate, secondary & flooded areas \\
\hline black-capped chickadee & Poecile atricapilla & obligate, weak excavator & above $600 \mathrm{~m}$ \\
\hline Carolina chickadee & Poecile carolinensis & obligate, secondary & below $600 \mathrm{~m}$ \\
\hline tufted titmouse & Baeolophus bicolor & obligate, secondary & central hardwoods \\
\hline red-breasted nuthatch & Sitta canadensis & obligate, weak excavator & spruce or mixed forests \\
\hline white-breasted nuthatch & Sitta carolinesis & obligate, secondary & mature hardwoods \\
\hline brown creeper & Certhia americana & facultative, secondary & mature forests above $750 \mathrm{~m}$ \\
\hline Carolina wren & Thryothorus ludovicianus & facultative, secondary & second-growth, brushy areas \\
\hline house wren & Trolodytes aedon & obligate, secondary & farmlands, suburban lands \\
\hline winter wren & Troglodytes troglodytes & facultative, secondary & spruce or mixed forests \\
\hline Eastern bluebird & Sialia sialis & obligate, secondary & semi-wooded or open areas \\
\hline European starling & Sturnus vulgaris & obligate, secondary & farmlands, suburban lands \\
\hline house sparrow & Passer domesticus & facultative, secondary & farmlands, suburban lands \\
\hline
\end{tabular}

${ }^{\mathrm{a}}$ Harrison (1975).

${ }^{\mathrm{b}}$ Hall (1983). 


\title{
CHAPTER 2
}

\section{TREE CAVITY RESOURCES FOR DEPENDENT CAVITY-USING WILDLIFE IN THE SOUTHERN ALLEGHENY MOUNTAINS}

\begin{abstract}
Forestlands in the southern Allegheny Mountains are unique due to the diversity and size of forest cover. Relict patches of red spruce (Picea rubens), for example, provide habitat for entire breeding populations for cavity-using wildlife species such as the federally endangered Virginia northern flying squirrel (Glaucomys sabrinus fuscus), and outlying breeding grounds for bird species such as the red-breasted nuthatch (Sitta canadensis). The main objective of this study was to assess and compare tree
\end{abstract} cavity resources for dependent wildlife among various forest cover types of the southern Allegheny Mountain region. This study was conducted in the Greenbrier and Potomac Ranger Districts of the Monongahela National Forest, West Virginia. From fall 1999 through spring 2001, 25 50-m radius study plots were established in each of a central hardwood, a northern hardwood, and a boreal forest cover type; respective Society of American Foresters (SAF) forest cover types used were white oak - black oak - northern red oak (Quercus alba-Q. velutina - Q. rubra), black cherry - maple (Prunus serotinaAcer spp.), and red spruce - yellow birch (Betula alleghaniensis). Plot inventories were tallied with BAF 10 prisms, and entire plots were searched for cavity trees. Cavity tree abundance significantly differed among the 3 forest cover types $(P<0.0001)$, with highest cavity tree abundance in the central hardwood type $(\tilde{\mathbf{x}}=16.4 ; \mathrm{SE}=5.3)$, followed by the

This chapter is in the style of Forest Science. 
northern hardwood type $(\overline{\mathrm{x}}=12.7 ; \mathrm{SE}=6.8)$, and lastly the boreal type $(\overline{\mathrm{x}}=7.2 ; \mathrm{SE}=$ 3.6). Relative cavity likelihood was highest for black locust (Robinia pseudoacacia), followed by American beech (Fagus grandifolia), sugar maple ( A. saccharum), and chestnut oak (Q. prinus). Black cherry and red spruce were least likely to harbor cavities. Abundance of excavated American beech cavities may be influenced by increased mortality from recent outbreaks of beech bark disease, initiated by the beech scale insect (Cryptococcus fagisuga). Biodiversity management of red spruce forests should consider numbers of large hardwoods, such as yellow birch, to provide cavity resources for dependent wildlife.

Additional Key words: Allegheny Mountains, cavity trees, relict forests, black locust, beech bark disease, Virginia northern flying squirrel.

A main challenge presently facing forest managers is harmonizing the various functions of multiple-use lands. One strategy commonly employed on public lands is ecosystem management, where managers strive to maintain desired ecological conditions while meeting other management objectives (Hicks 1998). However, ecological conditions will vary inherently with stand conditions, such as composition and age. For example, most cavities are in unhealthy or standing dead trees (i.e., snags) (Thomas et al. 1979, Davis 1983), and a variety of wildlife may use cavities as denning, nesting, or food-cache sites (McComb and Noble 1981, Davis 1983, Hunter 1990). Thus, tree cavity resources usually increase with stand age (tapering after about 100 years age for most forest types) 
(Newton 1994). Clearly, baseline information is necessary for gauging cavity resource availability among forest stands.

Some bird species, such as woodpeckers (Piciformes), will create nesting sites (i.e., primary cavity-nesters), yet most other wildlife species rely on available holes in live or dead trees for nesting or denning (i.e., secondary cavity nesters)(Thomas et al. 1979, Martin and Eadie 1999). Many cavity trees serve multiple uses: Carey (1983) described a black walnut (Juglans nigra) tree used sequentially over a 32-month period by honey bees (Apis mellifera), a pileated woodpecker (Drycopus pileatus) foraging on carpenter ants (Campanotus sp.) followed by 2 northern flickers (Colaptes auratus) feeding in the recent excavations, a nursing gray squirrel (Sciurus carolinensis), a nursing fox squirrel (S. niger), another nursing gray squirrel, a denning opossum (Didelphis virginiana), and lastly a third gray squirrel brood. Tree cavities have gained attention because the nest-site resource can be a limiting factor to some dependent hole-nesting bird populations (von Haartman 1957, Zarnowitz and Manuwal 1985, Johnson and Kermott 1994).

Concerns about possible negative impacts of some forest management activities on cavity-tree resources have led to numerous publications relating cavity abundances to forest characteristics (i.e., cover types, stand features) and at times management practices (Newton 1994). Carey (1983) provides a useful evaluation of cavity-tree resources in hardwood stands of the Monongahela National Forest (MNF) of West Virginia. Carey (1983) found more cavities within oak - hickory (Carya spp.) stands than within maple beech-birch stands. Carey (1983) concluded that random processes (e.g., natural pruning, 
fire, wind, and ice damage) generated variation in cavity tree abundances rather than other stand or tree features (e.g., topography, tree diameters at breast height [DBH]).

Given the importance of snags as trees for cavity-using wildlife (Conner 1978, Davis 1983, Showalter 2000), much attention has been given to these forest components in particular. For example, in contrast to data from the MNF (Carey 1983), Rosenberg et al. (1988) found more and larger snags than expected in older stands (>100 years) of the Jefferson National Forest in southwest Virginia. Considering management effects, Graves et al. (2000) found snags 2.6 and 3 times more abundant on uncut stands than on areas thinned from below (i.e., by removal of suppressed and overtopped trees) to $45 \%$ and $60 \%$ residual stand density, respectively, in a West Virginia forest. Likewise, Moriarty and McComb (1983) found timber stand improvement (TSI) via girdling of poor quality trees reduced snag levels in hardwood stands of eastern Kentucky. Furthermore, Stribling et al. (1990) found bird community richness and abundance significantly higher on TSI plots with snags retained than on control TSI plots in central Pennsylvania. Such studies often elucidate detrimental effects on wildlife populations from removing poor quality and/or dead trees from forest stands.

However, assumptions that a dearth of snags limits cavity-dependent wildlife populations are not always valid. In the MNF, Carey (1983) found that $70 \%$ and $95 \%$ of cavity trees deemed usable by birds and mammals, respectively, were live. Similarly, Sedgwick and Knopf (1986) found 2.3 usable-cavity trees/ha, yet only 0.66 snags/ha in cottonwood bottomlands of east Colorado. More so, suitable cavities are not always limiting factors to secondary-nesting wildlife. For example, by manipulating cavity availabilities and counting breeding secondary-nesting bird densities within oak-pine 
(Pinus sp.) study plots of central California, Waters et al. (1990) concluded that cavities were not limiting secondary-nesting breeding birds.

Generally, the Allegheny Mountains are considered within the central hardwoods region, yet northern hardwood and boreal forest types also can be found within the immediate area (Eyre, 1980; Hicks 1998). The physiographic Allegheny Mountain section of the Appalachian Plateau runs southwesterly from central Pennsylvania to the highest peaks of West Virginia (Fenneman 1938). At the highest elevations of the Allegheny Mountains in West Virginia, generally above $1000 \mathrm{~m}$, relict patches of boreal forests remain from cooler, periglacial times (Hall 1983). Moving down in elevation, forests become a mosaic between higher, north-facing northern hardwood types and lower, south-facing central hardwood stands (Hicks 1998).

The diversity among forests of the southern Allegheny Mountains provides a unique possibility to examine tree cavity resources among various forest types. Whereas Carey (1983) described cavity properties among a range of stand ages in central hardwoods (i.e., oak-hickory forests) and northern hardwoods (i.e., birch-beech-maple forests), opportunity exists to provide baseline comparison data among hardwood types, as well as boreal forest types, by studying only mature stands. Therefore, the objectives of my study were to: 1) compare cavity abundances among mature stands of boreal, northern hardwood, and central hardwood forest types; 2) identify which tree species, if any, are important cavity-producing species; 3) identify characteristic differences between cavity trees and other trees within stands; 4) compare present cavity resource information with past information; and 5) assess management implications of all findings. Null hypotheses I tested were: 1) there is no difference in cavity abundance among forest 
types, regardless of age, basal area, elevation, aspect, or slope of forest stands; 2) the likelihood of cavity abundance is equal among all tree species; 3) Cavity trees are no different than conspecifics in diameter and height.

\section{STUDY AREA}

The study was conducted on the Potomac and Greenbrier Ranger Districts of the MNF, in Pendleton, Pocahontas, and Randolph Counties, West Virginia. More than 80\% of Randolph and Pocahontas Counties are forested, whereas wider valleys in Pendleton County account for slightly more farmland and less forest (Buckelew and Hall 1994). The logging industry began in the region after the civil war, and the arrival of railways in the 1880s allowed lumber to be harvested more quickly (Clarkson 1993). The slash left behind provided fuel for fire, which ravaged areas and removed the topsoil (Clarkson 1993). Subsequently, the loss of the forest was blamed for floods that occurred in the region during the early 1900s (Clarkson 1993). These events led to the formation of the MNF in 1920 to protect the forest resources in the southern Allegheny Mountains.

Based on the classification system of the Society of American Foresters (SAF), 9 of the 255 numbered North American cover types commonly occur throughout the southern Allegheny Mountains (Eyre 1980). The SAF forest cover types are identified by tree species that comprise the majority of stand stocking. Central hardwood forest types, generally referred to as oak-hickory forests by U.S. Forest Service terminology, include the SAF forest cover types: chestnut oak (SAF type 44); white oak - black oak northern red oak (type 52), which includes the sub-type scarlet oak (Q. coccinea) chestnut oak; white oak (type 53); yellow-poplar (type 57); and yellow poplar - white 
oak - northern red oak (type 59) (Eyre 1980). Northern hardwoods, referred to by the U.S. Forest Service as maple - beech - birch forests, include SAF forest cover types: sugar maple (type 27); black cherry - maple (type 28), including both red and sugar maples; beech - sugar maple (type 60); and red maple (Acer rubrum) (type 108) (Eyre 1980). The relict sub-alpine stands are either classified as: red spruce (type 32) if the stands are pure (>80\% red spruce); or red spruce - yellow birch (type 30) where these species together comprise the majority of the stocking (Eyre 1980).

Prevailing winds come from the west, creating the greatest amounts of precipitation along the upper-west slopes and a rain-shadow effect along east slopes (Buckelew and Hall 1994). Thus, annual precipitation is highest in Randolph County (> $132 \mathrm{~cm} / \mathrm{yr})$, somewhat lower in Pocahontas County $(119.4-132 \mathrm{~cm} / \mathrm{yr})$, and lowest in Pendleton County (94-106.7 cm/yr) (Buckelew and Hall 1994). The average winter temperature in the western valley at Elkins, Randolph County is $-1{ }^{\circ} \mathrm{C}\left(31^{\circ} \mathrm{F}\right)$, and the average summer temperature is $19^{\circ} \mathrm{C}\left(67^{\circ} \mathrm{F}\right)$ with a maximum of $27^{\circ} \mathrm{C}\left(80^{\circ} \mathrm{F}\right)$ (Pyle et al. 1982). Interestingly, temperature averages in the eastern valley at Franklin, Pendleton County are $1^{\circ} \mathrm{C}\left(2^{\circ} \mathrm{F}\right)$ higher than the average temperatures in Elkins (Estepp 1992). Average temperatures along the Allegheny Mountain ridgeline are $-8^{\circ} \mathrm{C}\left(18^{\circ} \mathrm{F}\right)$ in winter, and $19^{\circ} \mathrm{C}\left(66^{\circ} \mathrm{F}\right)$ in summer with a maximum of $24^{\circ} \mathrm{C}\left(76^{\circ} \mathrm{F}\right)$ (Estepp 1992).

All study plots were within $27 \mathrm{~km}(16.8 \mathrm{mi})$ of a geographic center near Lost Run in Highland County, Virginia, which is about $11.8 \mathrm{~km}(7.3 \mathrm{mi})$ east of the Greenbrier District Ranger Station in Bartow, West Virginia. Thus, many study plots were scattered among the Cheat and Middle Mountain ridgelines to the west of the Allegheny Mountain divide, and some were placed at lower elevations along the east slope of the main divide. 
Elevation within this area is typical of the southern Allegheny Mountain region, ranging from about $540 \mathrm{~m}(1772 \mathrm{ft})$ to $1481 \mathrm{~m}(4861 \mathrm{ft})$ on Spruce Knob along the eastern divide in Pendleton County. However, relief usually ranges between $300 \mathrm{~m}(1000 \mathrm{ft})$ and 500 m (1600 ft) (Hall 1983). The terrain is hill-and-valley with some slopes near $70 \%$ grade; the prevailing ridges and rivers generally follow a south-west to north-east alignment (Pyle 1982).

Soil types reflect topography, climate, parent material, living organisms, and time (Estepp 1992). There are about 20 general soil association types within the study area; study plots were located on 10 of these soil associations: Berks - Weikert, Dekalb Berks - Calvin, Cateachie - Shouns - Belmont, Calvin - Shouns, Dekalb - Buchanan, Potomac - Tioga - Holly, Dekalb - Blackthorn - Elliber, Lehew - Hazleton, Mandy, and Calvin - Dekalb - Hazleton (Pyle 1982, Estepp 1992, Flegel 1999). Calvin - Shouns soils are often dominated by central hardwood tree species (Flegel 1999). Dekalb Buchanan soils, found in the Shaver's Fork drainage area in Randolph County, are generally productive yet may be subject to flooding (Pyle 1982). The widely ranging Berks - Weikert soils are often shallow, and are subject to drought and overgrazing on steep slopes (Estepp 1992, Flegel 1999). Mandy soils are almost exclusively within the MNF, and mainly produce sugar maple, or beech - maple stands (Flegel 1999). Cateachie soils, which typically produce sugar maple stands and mixed oaks at lower elevations, often present a slippage hazard due to steepness (Estepp 1992). Dekalb Blackthorn - Elliber soils, occurring mainly on upper slopes in Pendleton County, are well suited to wood production (Estepp 1992). 
Many specific soil types vary within each major association, and site indices were created for each soil type so that managers can predict tree growth on each location (Pyle 1982, Estepp 1992, Flegel 1999). Site indices vary widely throughout the study area, typically ranging from 35 to 80; values indicate the expected height of trees after 50 years growth (Pyle 1982, Estepp 1992, Flegel 1999).

\section{METHODS}

To analyze cavity resources among central hardwoods, northern hardwoods, and boreal forests of the southern Allegheny Mountains, I chose to focus on 1 SAF forest cover type in each general forest category so variations in stand compositions among categories could be minimized. I also used an arbitrary minimum stand age of 90 years so that only mature stands would be compared, yet a practical amount of usable stands would exist. I chose the white oak - black oak - northern red oak type as a central hardwood because each of these species is commercially important and common associates include most other central hardwood species. I also focused on black-cherry maple stands among northern hardwoods because of the current importance of black cherry veneer in timber markets. To reduce possible bias resulting from different species growth forms, I chose to focus on red spruce - yellow birch rather than pure red spruce as a boreal forest cover type.

\section{Plot Establishment}

I obtained a list of forest stands $\geq 90$ years old on the Cheat/Potomac and Greenbrier Ranger Districts in September, 1999. The database lists stands, by 
compartment, along with forest type, area, age, basal area, and management area. Forest service personnel advised me of about 20 compartments that contained high percentages of the SAF forest cover types upon which I was focusing my study. From these, I randomly selected appropriate stands in which to establish study plots. I avoided areas with recent or intense management activity, and areas more than $1200 \mathrm{~m}$ from a drivable road. Using compartment maps from the Forest Service, I selected a random distance and compass bearing from an access point to establish the center for each $50 \mathrm{~m}$ radius plot (0.78 ha). Each plot was within 1 mapped stand, and plots were at least $250 \mathrm{~m}$ apart for independent sampling (Ralph et al. 1995). I set up 25 plots in each SAF cover type for a total of 75 plots (Figure 1). All plots were established when leaves were absent from trees to facilitate cavity searching. Thirty plots (10 per forest type) were established by May 2000; all others were set up by May 2001.

\section{Plot Inventory and Cavity Search}

Plot UTM coordinates were determined from satellite signals received by a Trimble Global Positioning System (GPS) placed at each plot center. Center point slope and prevailing aspect were recorded (Marcot 1983, Marzluff and Lyon 1983). I determined plot elevations, mean daily maximum and minimum temperatures per year, and annual precipitation rates using geographic information systems (GIS) analysis; by overlaying center point location information on digital grid coverages (with cell sizes of $90 \mathrm{~m}$ ) of West Virginia using ArcView GIS software. Coverages of elevation, temperature, and precipitation were provided by the West Virginia Natural Resources Analysis Center (West Virginia Natural Resources Analysis Center 2001). In summer 
months I estimated percent overstory cover (codominant and dominant canopy), understory cover ( $<2 \mathrm{~m}$ tall to overtopped canopy), and shrub cover ( $<2 \mathrm{~m}$ tall) of each plot by averaging 4 measurements of each: estimates at center points and estimates at 3 random equidistant points about $25 \mathrm{~m}$ from the plot center.

I sampled center points via a prism with a basal area factor of 10 to determine basal area and tree tallies within plots. For each tallied tree the species, diameter at $1.5 \mathrm{~m}$ (DBH), and height (determined with a clinometer) were recorded. The health of each sampled tree also was recorded on a scale of $1-7$, where 1 is a healthy codominant tree (Maser et al. 1979) (Table 1). The number of fungal conks, cavities and damage (i.e., broken top, branch, or both at >10 cm diameter) were recorded (Runde and Capen 1987, Rodewald and Smith 1998) for each tree as well. In considering all secondary cavitynesting species of interest, the smallest usable tree size listed by Degraaf and Shigo (1985) was a DBH of $10.15 \mathrm{~cm}$ (4 in) for black-capped chickadee (Poecile atricapilla) nest cavities, so only trees $>10 \mathrm{~cm}$ DBH were tallied.

With an assistant, I counted all cavity trees by splitting plots into 6 "pie" sections lined by 50 -meter tapes and tagging each located tree. Binoculars aided cavity searches. Harrison (1975) provides minimum average nest-cavity dimensions of $6 \mathrm{~cm}$ (2 3/8 in) diameter and about $12.7 \mathrm{~cm}$ (5 in) deep, with an opening of about $3.5 \mathrm{~cm}$ (1 3/8 in) (for black-capped chickadees). Therefore, cavities were counted when estimated to be at least $5 \mathrm{~cm}$ diameter by $10 \mathrm{~cm}$ deep with an opening $>3 \mathrm{~cm}$. The species, $\mathrm{DBH}$, health, height, number of fungal conks, presence of damage, number of cavities, cavity origin (i.e., excavated or non-excavated), and opening size (width and height) were recorded for every cavity tree found within the plot. 


\section{Statistical Analyses}

To improve normality all percentage data (e.g., slope, overstory cover, understory cover) were arcsine transformed (Zar 1999). Other data were similarly treated using logarithmic transformations when Kolmogorov-Smirnov goodness of fit tests showed normality was thereby improved (Zar 1999). Circular distributions (e.g., plot aspects, cavity openings) were checked for uniformity using the Rayleigh test (Zar 1999).

Analyses of covariance (ANCOVA) were used to find differences in tree cavity abundances among forest cover types for all cavities, and for excavated cavities only. Because cavity abundances may vary accordingly with other plot features (e.g., basal area, tree count, stand age, slope), the suitability of each feature as a concomitant variable in ANCOVA regression models was tested in an additive, stepwise fashion (Dowdy and Wearden 1991). Rayleigh tests showed sufficient evidence to suggest uniform plot distributions for plot aspects in the RS - YB $(P=0.330), \mathrm{BC}-\mathrm{M}(P=0.249)$, and WO BO - NRO $(P=0.336)$ forest cover types. Thus, because north-facing stands may have different growth characteristics than south-facing stands, aspect blocks (north and south) were included in the ANCOVA designs.

I used Tukey's test for multiple comparisons to separate means when significant differences among treatments were suggested. I used log-likelihood ratios (i.e., $G$ tests) to find which tree species are more and which species are less likely to contain cavities. All tests were significant at $P<0.05$. Sequential testing among species allowed for multiple comparisons between species. I did similar tests counting excavated cavities only. To compare heights, diameters, and decay classes of cavity trees to inventory (i.e., 
trees tallied by center point prism methods) conspecifics, I compared mean plot values using paired $t$-tests for each common species using available data.

\section{RESULTS}

A total of 912 cavities was found in 707 cavity trees greater than $10 \mathrm{~cm} \mathrm{DBH.} \mathrm{Of}$ the 707 cavity trees, 249 trees contained cavities excavated by woodpeckers. Over 25 tree species were tallied in cavity tree counts and prism counts; about half of these were commonly encountered. The 75 plots were established among 48 forest stands in 16 compartments of the MNF. Forest stands used ranged in area from 2.83 ha to 50.18 ha. The oldest stand age was 188 years, while $78 \%$ of stands were $90-110$ years old. The mean age of $\mathrm{RS}-\mathrm{YB}$ plots was significantly older than $\mathrm{BC}-\mathrm{M}$ and $\mathrm{WO}-\mathrm{BO}-\mathrm{NRO}$ plots $(F=11.45, \mathrm{df}=2,72, P<0.0001)$ (Table 2$)$. However, no difference in mean basal areas $(F=0.08, \mathrm{df}=2,72, P=0.924)$ or stems per plot $(F=2.86, \mathrm{df}=2,72, P=0.064)$ were detected among the forest cover types (Table 2).

Red spruce accounted for $50.3 \%$ of the mean plot basal area of the $25 \mathrm{RS}-\mathrm{YB}$ plots, and yellow birch comprised $24.5 \%$ of the mean RS - YB basal area (Figure 2). Also, red spruce and yellow birch accounted for $41.5 \%$ and $32.3 \%$ of the mean RS - YB stems counts, respectively (Figure 3). Other common tree species on RS - YB plots included American beech, black cherry, eastern hemlock (Tsuga canadensis), and red maple (Figures 2, 3). Black cherry was the most commonly tallied tree on BC - M plots (29.1\% of mean basal area), followed by sugar maple (23.4\% of mean basal area) and red maple (12.4\% of mean basal area) (Figures 4, 5). Northern red oak occupied $30.9 \%$ of the $\mathrm{WO}-\mathrm{BO}-\mathrm{NRO}$ basal area and $22.1 \%$ of the mean stem count per plot (Figures 6 , 
7). Red maple averaged more stems than northern red oak, but occupied less mean basal area on WO - BO - NRO plots (Figures 6, 7). Chestnut Oak, white oak, black oak, sugar maple, and black locust also were commonly counted in prism tallies (Figures 6, 7).

\section{Cavity Occurrence Among Forest Cover Types}

The stepwise procedure selected precipitation, $\%$ understory cover, basal area, and inventory stem counts as covariates in the ANCOVA model. When also controlling for plot aspect, ANCOVA results suggest mean cavity tree abundances differed among $\mathrm{RS}-\mathrm{YB}, \mathrm{BC}-\mathrm{M}$, and $\mathrm{WO}-\mathrm{BO}-\mathrm{NRO}$ forest cover types $(F=5.02, \mathrm{df}=2,67, P=$ 0.009). Tukey's test results show inequality among all forest cover types in mean cavity abundance per plot $(P<0.05)(\mathrm{WO}-\mathrm{BO}-\mathrm{NRO}: \overline{\mathrm{x}}=16.4, \mathrm{SE}=5.3, \mathrm{BC}-\mathrm{M}: \overline{\mathrm{x}}=12.7$, $\mathrm{SE}=6.8, \mathrm{RS}-\mathrm{YB}: \overline{\mathrm{x}}=7.2, \mathrm{SE}=3.6$ ). Precipitation, $\%$ understory cover, basal area, stem count, and plot aspect together accounted for $53.19 \%$ of the variability in cavity abundances among plots.

When counting trees with excavated cavities only, the stepwise procedure selected precipitation, $\%$ overstory cover, $\%$ understory cover, $\%$ shrub cover, basal area, and inventory stem counts as covariates in the ANCOVA model. Again controlling for plot aspect, ANCOVA suggests that mean excavated cavity tree abundances do not differ among $\mathrm{RS}-\mathrm{YB}(\overline{\mathrm{x}}=3.3, \mathrm{SE}=0.46), \mathrm{BC}-\mathrm{M}(\overline{\mathrm{x}}=4.2, \mathrm{SE}=0.63)$, and $\mathrm{WO}-\mathrm{BO}-$ $\mathrm{NRO}(\overline{\mathbf{x}}=5.1, \mathrm{SE}=0.74)$ forest cover types $(F=0.83, \mathrm{df}=2,65, P=0.441)$. The ANCOVA model accounted for $33.16 \%$ of the variability in excavated cavity abundances among plots. 


\section{Cavity Occurrence Among Tree Species}

More cavities occurred in American beech and sugar maple than other species (15.84\% and $15.13 \%$ of all cavities, respectively) (Figure 8 ). Together with yellow birch, red maple, black locust, chestnut oak, and northern red oak, these species accounted for > $75 \%$ of all cavities found. American beech, black locust, sugar maple, and yellow birch accounted for $>60 \%$ of all excavated cavities. Although red maple was the most common tree among all plots, black locust had the highest proportion of inventory trees with cavities (23.7\% of stems had cavities) (Figure 9).

Log-likelihood tests show that black locust, followed by American beech, are significantly more likely to have cavities than stems of all other species (Table 3). Conversely, northern red oak, black cherry, and red spruce were least likely to have cavities. Results were similar when counting excavated cavities only (Table 3).

\section{Cavity Tree Characteristics}

When comparing mean diameters of inventory trees to conspecific cavity trees on a by-plot basis, cavity trees were significantly larger than inventory trees (Table 4). In no instance was the mean diameter of inventory trees larger than conspecific cavity trees (Table 4). However, only red spruce showed significant differences in height between inventory trees and cavity trees $(t=6.18, P<0.0001)$ (Table 5). Most $(51.79 \%)$ American beech cavity trees had broken boles (at $>10 \mathrm{~cm}$ diameter), whereas $33.33 \%$ of conspecific inventory trees had broken boles. Similarly, $90.48 \%$ of the red spruce cavity trees had broken boles, compared to $90.37 \%$ of the inventory trees with intact boles. 
Cavity trees of all species combined were more decayed than inventory trees in by-plot comparisons $(t=2.42, P=0.023)$. However, most oaks and maples with cavities were not snags, but live trees. Cavity trees in black locust and American beech tended to be snags in various stages of decay. Yellow birch cavity trees varied widely among stages of decay, yet $80.67 \%$ of inventory stems were live.

\section{DISCUSSION}

\section{Cavity Tree Comparisons Among Forest Types}

Differences in cavity abundance among $\mathrm{RS}-\mathrm{YB}, \mathrm{BC}-\mathrm{M}$, and $\mathrm{WO}-\mathrm{BO}-\mathrm{NRO}$ forest cover types were not due to differences in stand ages, basal area, or number of standing stems. The relatively lower cavity tree rate among RS - YB stands was most likely due to the large proportion of live spruce trees within these stands, even though these stands tended to be older. Live conifer trees are known to provide poor nesting and denning opportunities for wildlife (Van Balen et al. 1982). Thus, variations in growth forms of major tree species in each forest cover type also were likely causes for differences in cavity tree abundances. The strong apical dominance and natural pruning characteristics of red spruce will leave only boles (and not branches) as possible cavity sites.

Even with binoculars and no foliage, cavities among hardwoods were difficult to detect. Some portions of large, laterally growing branches couldn't be seen from the ground, so possibly cavities were missed. Healy et al. (1989) estimated that $80 \%$ of hardwood cavities were detected by binoculars from the ground in a similar study. However, the differences in growth forms between the red spruce and hardwoods, 
coupled with the presence of foliage on the spruce, appeared to balance cavity detectability among the tree species and hence, forest cover types.

Woodpecker excavations did not account for differences in cavity abundances among the forest cover types studied. Among the oak species combined, only $20.5 \%$ of all cavities were excavated. Similarly, among black cherry and the maples combined, only $25.6 \%$ of all cavities were excavated. However, $76.2 \%$ of red spruce cavities and $45.8 \%$ of yellow birch cavities were excavated. Clearly, cavities formed by wood decay were predominant among $\mathrm{WO}-\mathrm{BO}-\mathrm{NRO}$ and $\mathrm{BC}-\mathrm{M}$ forest types, and accounted for differences in cavity abundance among the forest cover types. Additionally, cavities initiated by decay tended to be in the larger diameter trees within plots. Structurally, larger trees of harder wood may be able to better survive injury from damaging agents, such as fire or wind, yet these agents will provide avenues for decay-causing fungi (Oliver and Larson 1996).

\section{Cavity Tree Comparisons Among Tree Species}

Carey (1983) found 10.3 cavity trees/ha in 94 to 126 year old maple-beech-birch stands in the Cheat Ranger District of the MNF, slightly lower than the 12.7 cavity trees/ha I found among BC - M plots in the Greenbrier and Potomac Ranger Districts. Beech comprised $36.7 \%$ of the cavity trees and only $13.5 \%$ of the inventory stems in the BC - M plots I measured. In contrast, Carey (1983) found 29\% of the maple-beech-birch cavity trees were American beech, while beech comprised $18 \%$ of the inventory point samples. 
Almost all beech trees $>10 \mathrm{~cm} \mathrm{DBH}$ appeared affected by beech bark disease, initiated by the beech scale (Tubbs and Houston 1990). After the beech scale insect attacks the bark, trees become susceptible to canker fungi (Nectria sp.) (Tubbs and Houston 1990). A wave of mortality from the disease began on the MNF in the 1990s (Houston 1994); it is likely that when sampling in 1980, Carey (1983) did not find the effects of the disease so widespread. Many of the trees (live and dead) affected by beech bark disease were excavated by woodpeckers and had broken boles. Large broken branches heal relatively slowly, thus many fungi have ample opportunity to penetrate and decay heart wood (Tubbs and Houston 1990).

Large sugar maples are a major part of the cavity tree resource in $\mathrm{BC}-\mathrm{M}$ stands. Shade tolerant sugar maples and beeches gain growing space through slow-growing, advanced regeneration (Godman et al. 1990). Because growth is slow, it is likely that larger sugar maples are among the oldest trees in forest stands, and some trees may be left from previous cuttings. Left in open growing conditions, sugar maple boles are then subject to epicormic branching (Godman and Brooks 1971), and these side branches may be naturally pruned as competition from faster growing competitors increases. Breakage sites provide spots for fungal attack (Godman et al. 1990). Also, sugar maple terminal buds are subject to forking, especially as trees age (Godman et al. 1990). Breakage increases as forked branches gain mass, thus providing a genesis for cavity formation.

Sugar maple generally outcompetes yellow birch in stands where they coexist (Erdmann 1990). Sugar maple roots may produce an exudate that inhibits root growth of yellow birch, thus providing the maple a growth advantage (Godman et al. 1990). However, most cavities in RS - YB stands are in yellow birch trees. More than $81 \%$ of 
excavated yellow birch trees ( $46 \%$ of all yellow birch cavity trees) were of advanced decay, and with broken tops. Excavated red spruce cavity trees (71\% of all red spruce cavity trees) tended to be in a similar condition. Weak excavating species, such as the red-breasted nuthatch, rely on softer snags for nesting opportunities (DeGraaf and Shigo 1985). Also, it is likely that red squirrels and flying squirrels depend on sounder yellow birch or other northern hardwoods for available cavities.

Like sugar maple, red maple also may tolerate relative shade in the understory for years before becoming released by canopy gaps (Walters and Yawney 1990). However, red maples seldom live longer than 150 years (compared to >300 years for sugar maple), and generally do not attain the diameter growth of sugar maple (Godman et al. 1990, Walters and Yawney 1990). Indeed, red maple inventory and cavity trees had much less diameter growth than other common species of $\mathrm{BC}-\mathrm{M}$ stands, indicating that most were understory trees. Still, red maple is considered a softer wood than sugar maple, and decay advances much faster in red maple than sugar maple (Walters and Yawney 1990). Nonetheless, red maple displayed a disproportionately low amount of excavated cavities. Most inventory and cavity trees were poor-formed, live trees without broken boles or branches. In all, red maple is probably too limited by diameter growth to be considered an important cavity tree.

Likewise, black cherry apparently does not significantly contribute to tree cavity resources among $\mathrm{BC}-\mathrm{M}$ stands. A shade intolerant, fast-growing pioneer species, black cherry trees show strong apical and epinastic control (Marquis 1990). Thus, most boles are long, either single or forked, with small crowns unfit for cavity formation. Because black cherry trees are generally dominant in the canopy up to about 80 years, they are 
subject to wind and storm breakage (Marquis 1990). However, decay spreads relatively slowly in black cherry, and thus the species is not prone to cavity formation.

Black locust is a shade-intolerant, pioneer species of mixed mesophytic forests, yet single-tree gaps in closed canopies may allow enough growing space for reestablishing black locust trees (Huntley 1990). Whereas sugar maple and beech are shade tolerant, slow-growing northern hardwoods, black locust relies on rapid growth to pioneer forest gaps in central hardwood stands (Huntley 1990). Because of the hardness and durability of black locust wood, it is commonly used for fence posts and railroad ties, for example (Huntley 1990). Also, growing success of black locust decreases with increasing slope, such as along the steep slopes of the MNF (Brown 1962). These qualities combine to make black locust an excellent snag and cavity resource in the MNF. Overtopped trees will not survive, yet black locust snags become a long-lasting, wellused resource for excavating species. Additionally, Sanderson et al. (1975) noted the importance of excavated black locust snags as potential gray squirrel cavity trees in West Virginia. In fact, less than $10 \%$ of black locust inventory trees were healthy, and all black locust cavity trees were unhealthy or dead.

Similarly, Carey (1983) found a disproportionate number of black locust with cavities in the Cheat Ranger District of the MNF. However, Carey (1983) found chestnut oak and northern red oak comprised higher percentages of the total cavity tree count than black locust $(44 \%, 19 \%$, and 10\%, respectively). In contrast, I found a significantly higher percentage of black locust cavity trees than all other species.

Chestnut oak had the highest cavity tree rate of all oak species, yet cavity tree likelihood was not significantly different from black oak. Chestnut oak has a higher 
incidence of decay associated with fire among the steep slopes of the Appalachians than many other oak species, although fire damage to all oaks can allow fungal attacks (McQuilkin 1990). I observed probable fire damage on several plots, which may possibly explain the relatively high cavity tree rate among chestnut oaks. The boles of many central hardwoods that had cavities near the butt also had some evidence of charring. Chestnut oak also was the oak species most likely to be excavated. However, most trees of all oak species appeared undamaged.

A study of gypsy moth damage among several tree species shows highest negative trends in health of northern red oaks and chestnut oaks after defoliation (Showalter 2000). Nevertheless, of the oaks, cavity likelihood was lowest in red oaks, but not significantly lower than in white oak. Although it isn't clear which cavities are caused by gypsy moth defoliation, it does not appear that such damage contributes significantly to the cavity tree resources in the MNF.

Within central hardwood stands of southeast Missouri, black oaks had significantly more cavities than white oaks (Allen and Corn 1990). I found no significant difference in cavity tree likelihood between these 2 species. However, black oak probably occupies less of the basal area in MNF stands than among the forests of Missouri, and possibly basal area isn't large enough to show a difference. Northern red oak occupies much more of the central hardwood forests of the MNF than black oak. 


\section{MANAGEMENT IMPLICATIONS}

\section{Wildlife Species}

Providing adequate resources for cavity-using wildlife among the relict red spruce forest "islands" in the southern Allegheny Mountains will aid in conserving the unique diversity of the region. Red spruce will not provide long lasting snags. The most destructive fungi Phellinus pini and Phaeolus schweinitzii chiefly occur in already declining and damaged trees, thus accelerating snag loss (Blum 1990). However, the soft snags of red spruce (and yellow birch) will provide nesting opportunities for weak excavating bird species. Red-breasted nuthatches, for example, are limited in breeding to the higher elevations in the southern Allegheny Mountain region (Buckelew and Hall 1994). Similarly, black-capped chickadees prefer mixed deciduous-coniferous and northern hardwoods in West Virginia (Buckelew and Hall 1994).

Yellow-bellied sapsuckers (Sphyrapicus varius), decreasing in numbers since the 1920s, also are confined in the region to breeding in middle elevations within the Allegheny Mountains (Hall 1983). Yellow birch can be an important summer food source for sapsuckers, and increased foraging may kill trees (Erdmann 1990). Yellowbellied sapsuckers also may inflict mortality on red spruce while foraging (Blum 1990). Thus, providing proficient nesting opportunities in other forest types may benefit cavitynesting species of the RS - YB forest cover types by increasing snag resources.

Virginia northern flying squirrels and red squirrels must rely upon appropriately sized cavities for denning. Both squirrel species rely heavily on red spruce as food sources (Blum 1990, Mitchell 2001). It's not likely that cavities excavated by nuthatches or chickadees provide ample space or adequate protection; squirrels probably rely on 
cavities formed by fungal decay. These cavities will occur most often in the larger yellow birch, sugar maple, and American beech that grow either within RS - YB stands or in surrounding northern hardwood forests. Adjacent to or within RS - YB stands, poorly formed sugar maples and beeches should be available as cavity resources for these wildlife species.

\section{Tree Species}

Caution should be used when assessing the value of American beech as a cavity tree resource. Beech bark disease was first reported to North America in Nova Scotia in the 1890s, and has spread westward and southward since being introduced (Acciavatti et al. 1993, Houston 1994). Usually, when beech bark disease infects a forest for the first time, a high proportion of large, mature trees are killed (Tubbs and Houston 1990). It is likely that many of the large beech cavity snags presently found in the MNF are a direct result of the beech bark disease. Many of the beech snags were excavated by woodpeckers. Tubbs and Houston (1990) reported high current mortality rates in some southern and western areas of the Adirondack Mountain region. In 1999-2001, the front of high beech mortality was probably beginning at the MNF. After the killing front subsides, stands are replaced with small trees that are inadequate for cavity formation (Houston 1994). Also, mortality is rare in stands in the aftermath of the disease front (Tubbs and Houston 1990).

Carey (1983) suggested that cavity abundance depends on local processes that affect individual trees, such as fire, wind, or storm damage. I found evidence to support his conclusions. Black locust regeneration among mature forest canopies of central 
hardwoods depends on canopy gaps. Black locust are poorly formed trees, yet snags have longevity and are major excavating sites for woodpeckers. Similarly, most of the live oaks with cavities were not healthy, well-formed trees. Of the oaks, chestnut oak is a superior cavity tree species.

\section{FUTURE RESEARCH}

To protect the relict spruce stands along the Appalachian Mountains, research should continue to focus on explanations for observed increases in spruce mortality rates. Within red spruce stands, home range information of the endangered Virginia northern flying squirrels will aid conservation efforts. Use versus availability information among forest stands with differing amounts of red spruce should be assessed among home ranges of flying squirrels. Such information will be useful in evaluating the potentiality of hardwood cavity trees. Additionally, the relative importance to weak excavating bird species of existing versus excavated cavities in RS - YB stands should be evaluated. Gathering cavity use information will afford better judgment concerning snag resources within the remnant red spruce forest cover types.

To better understand the current situation of American beech as a cavity resource, long-range studies should be considered. It appears that the initial killing front of beech bark disease is now occurring on the MNF. Smaller beech regenerating in the aftermath of the mortality front are not likely to contain suitable cavities. The relative proportions of beech within overstory canopies as well as the relative contributions to cavity tree resources within the MNF should periodically be evaluated to understand the long-term effects of beech bark disease. 
Within central hardwood cover types, as well as other forest cover types, the relative suitability of $\mathrm{WO}-\mathrm{BO}$ - NRO for providing cavity-wildlife cover should be compared to other cover types, such as pure chestnut oak and pure northern red oak. Wildlife use data among cover types will address this issue. Additionally, stands of various ages of the same forest cover type can similarly be assessed. 


\section{LITERATURE CITED}

Acciavatti, R. E., T. J. Allen, A. R. Miller, L. L. Pechuman, B. C. Kondratieff, R. F. Kirchner, A. G. Wheeler, Jr., S. M. Clark, E. van den Berghe, and W. J. Arnold. 1993. P. 143-178 in Upland forests of West Virginia. Stephenson, S. L., (ed.). McClain Printing Company, Parsons, West Virginia.

Allen, A. W., and J. G. Corn. 1990. Relationships between live tree diameter and cavity abundance in a Missouri oak-hickory forest. N. J. Appl. For. 7:179-183.

Blum, B. M. 1990. Picea rubens Sarg. Red spruce. P. 250-259 in Silvics of North America. Vol. 1. Conifers. Burns, R. M., Honkala, B. H. (tech. coords). USDA Agric. Handb. Washington, D.C.

Braun, E. L. 1950. Deciduous forests of eastern North America. The Blakiston Company, Philadelphia, Pennsylvania, USA.

Brown, J. H. 1962. Success of tree plantings on strip-mined areas in West Virginia. West Virginia University Agric. Exp. Sta. Bull. 473. Morgantown, West Virginia.

Buckelew, A. R., Jr., and G. A. Hall. 1994. The West Virginia breeding bird atlas. University of Pittsburgh Press, Pittsburgh, Pennsylvania, USA.

Carey, A. B. 1983. Cavities in trees in hardwood forests. Pages 167-184 in Snag habitat management: Proceedings of the symposium. Davis, J. W., G. A. Goodwin, and R. A. Ockenfels (tech. coords). USDA For. Serv. Gen. Tech. Rep. RM-99.

Carvell, K. L. 1986. Effect of past history on present stand composition and condition. Pages 1-7 in Guidelines for managing immature Appalachian hardwood stands. 
Smith, H. C., and M. C. Eye (eds). West Virginia University Books, Morgantown, West Virginia.

Clarkson, R. B. 1993. Destruction of the upland forests by lumbering and fire. Pages 35-65 in Upland forests of West Virginia. Stephenson, S. L., (ed.). McClain Printing Company, Parsons, West Virginia.

Conner, R. N. 1978. Snag management for cavity nesting birds. Pages 120-128 in Proceedings of the workshop management of southern forests for nongame birds. DeGraaf, R. M. (tech. coord.). USDA For. Serv. Gen. Tech. Rep. SE-14.

Davis, J. W. 1983. Snags are for wildlife. Pages 4-9 in Snag habitat management: Proceedings of the symposium. Davis, J. W., G. A. Goodwin, and R. A. Ockenfels (tech. coords). USDA For. Serv. Gen. Tech. Rep. RM-99.

DeGraaf, R. M., and A. L. Shigo. 1985. Managing cavity trees for wildlife in the Northeast. USDA For. Serv. Gen. Tech. Rep. NE-101. 23pp.

Dowdy, S. M., and S. Wearden. 1991. Statistics for research. John Wiley and Sons, Incorporated. New York, New York, USA. 629 p.

Erdmann, G. G. 1990. Betula alleghaniensis Britton. yellow birch. pp 133 - 147 in Silvics of North America. Vol. 2. Hardwoods. Burns, R. M., Honkala, B. H. (tech. coords). USDA Agric. Handb. 654. Washington, D.C.

Estepp, R. 1992. Soil survey of Pendleton County, West Virginia. Nat. Coop. Soil Survey.

Eyre, F. H. 1980. Forest cover types of the United States and Canada. Soc. Am. For., Washington, DC, USA. 
Fenneman, N. M. 1938. Physiography of eastern United States. McGraw-Hill Book Co., New York City, New York, USA.

Filip, S. M. 1978. Impact of beech bark disease on uneven-age forest management of a northern hardwood forest. USDA For. Serv. Gen. Tech. Rep NE-45. NE For. Exp. Sta., Broomall, Pennsylvania, USA. 7p.

Flegel, D. G. 1999. Soil survey of Pocahontas County, West Virginia. Nat. Coop. Soil Survey.

Godman, R. M., and D. J. Books. 1971. Influence of stand density on stem quality in pole-size northern hardwoods. USDA For. Serv. Res. Paper NC - 54. N Cen. For. Exp. Sta., St. Paul, Minnesota, USA.

, H. W. Yawney, and C. H. Tubbs. 1990. Acer saccharum Marsh. sugar maple. . pp 605 - 613 in Silvics of North America. Vol. 2. Hardwoods. Burns, R. M., Honkala, B. H. (tech. coords). USDA Agric. Handb. 654. Washington, D.C. Graves, A. T., M. A. Fajvan, and G. W. Miller. 2000. The effects of thinning intensity on snag and cavity tree abundance in an Appalachian hardwood stand. Can. J. For. Res. 30:1214-1220.

Hall, G. A. 1983. West Virginia Birds. Carnegie Museum of Natural History Special Publication No. 7, Pittsburgh, Pennsylvania, USA. 180 p.

Harrison, H. H. 1975. Birds' nests. Houghton Mifflin Company, New York, New York. $257 \mathrm{p}$.

Healy, W. M., R. T. Brooks, and R. M. DeGraaf. 1989. Cavity trees in sawtimber-size oak stands in central Massachusetts. N. J. Appl. For. 6:61-65. 
Hicks, R. R., Jr. 1998. Ecology and Management of central hardwood forests. John Wiley \& Sons, New York City, New York, USA.

Houston, D. R. 1994. Major new tree disease epidemics: beech bark disease. Annu. Rev. Phytopathol. 32:75-87.

Hunter, M. L. 1990. Dying, dead, and down trees. Pages 157-180 in Wildlife, forests, and forestry: principles of managing forests for biological diversity. Prentice Hall, Englewood Cliffs, New Jersey, USA.

Huntley, J. C. 1990. Robinia pseudoacacia L. black locust. pp 751-761 in Silvics of North America. Vol. 2. Hardwoods. Burns, R. M., Honkala, B. H. (tech. coords). USDA Agric. Handb. 654. Washington, D.C.

Johnson, L. S., and L. H. Kermott. 1994. Nesting success of cavity -nesting birds using natural tree cavities. J. Field Ornith. 65:36-51.

MacArthur, R. H., and E. O. Wilson. 1967. The theory of island biogeography. Princeton University Press, Princeton, New Jersey, USA.

Marcot, B. G. 1983. Snag use by birds in Douglas-fir clearcuts. Pages 134-139 in Snag habitat management: Proceedings of the symposium. Davis, J. W., G. A. Goodwin, and R. A. Ockenfels (tech. coords.). USDA For. Serv. Gen. Tech. Rep. RM-99.

Marquis, D. A. 1990. Prunus serotina Ehrh. black cherry. pp. 594-604 in Silvics of North America. Vol. 2. Hardwoods. Burns, R. M., Honkala, B. H. (tech. coords). USDA Agric. Handb. 654. Washington, D.C. 
Martin, K., and J. M. Eadie. 1999. Nest webs: A community-wide approach to the management and conservation of cavity-nesting forest birds. For. Ecol. and Manage. 115:243-257.

Marzluff, J. M., and L. J. Lyon. 1983. Snags as indicators of habitat suitability for open nesting birds. Pages 140-146 in Snag habitat management: Proceedings of the symposium. Davis, J. W., G. A. Goodwin, and R. A. Ockenfels (tech. coords). USDA For. Serv. Gen. Tech. Rep. RM-99.

Maser, C., R. A. Anderson, K. Cromack, Jr., J. T. Williams, R. E. Martin. 1979. Dead and down woody material. Pages 78-95 in Wildlife habitats in managed forests of the blue mountains of Oregon and Washington. Thomas, J. W. (ed.). USDA Agric. Handb. 553.

McComb, W. C., and R. E. Noble. 1981. Herpetofaunal use of natural tree cavities and nest boxes. Wildl. Soc. Bull. 9:261-267.

McQuilkin, R. A. 1990. Quercus prinus L. chestnut oak. pp. 594-604 in Silvics of North America. Vol. 2. Hardwoods. Burns, R. M., Honkala, B. H. (tech. coords). USDA Agric. Handb. 654. Washington, D.C.

Mitchell, D. 2001. Spring and fall diet of the endangered West Virginia northern flying squirrel (Glaucomys sabrinus fuscus). Am. Midl. Nat. 146:439-443.

Moriarity, J. J., and W. C. McComb. 1983. The long-term effect of timber stand improvement on snag cavity densities in the central Appalachians. Pages 40-44 in Snag habitat management: Proceedings of the symposium. Davis, J. W., G. A. Goodwin, and R. A. Ockenfels (tech. coords.) USDA For. Serv. Gen. Tech. Rep. RM-99. 
Newton, I. 1994. The role of nest sites in limiting the numbers of hole-nesting birds: A review. Biol. Conserv. 70:265-276.

Odom, R. H., W. M. Ford, J. W. Edwards, C. W. Stihler, and J. M. Menzel. 2001. Developing a habitat model for the endangered Virginia northern flying squirrel (Glaucomys sabrinus fuscus) in the Allegheny Mountains of West Virginia. Biol. Conserv. 99:245-252.

Oliver, C. D., and B. C. Larson. 1996. Forest stand Dynamics. John Wiley and Sons, Incorporated. New York, New York, USA.

Pyle, R. E., W. W. Beverage, T. Yoakum, D. P. Amick, W. F. Hatfield, and D. E. McKinney. 1982. Soil survey of Randolph County area main part, West Virginia. Nat. Coop. Soil Survey.

Ralph, C. J., J. R. Sauer, and S. Droege, editors. 1995. Monitoring bird populations by point counts. USDA For. Serv. Gen. Tech. Rep. PSW-GTR-149.

Rodewald, P. G., and K. G. Smith. 1998. Short-term effects of understory and overstory management on breeding birds in Arkansas oak-hickory forests. J. Wildl. Manage. 62:1411-1417.

Rosenberg, D. K., J. D. Fraser, and D. F. Stauffer. 1988. Use and characteristics of snags in young and old forest stands in southwest Virginia. For. Sci. 34:224-228.

Runde, D. E., and D. E. Capen. 1987. Characteristics of northern hardwood trees used by cavity-nesting birds. J. Wildl. Manage. 51:217-223.

Sanderson, H. R., W. M. Healy, J. C. Pack, J. D. Gill, and J. W. Thomas. 1975. Gray squirrel habitat and nest tree preference. Proc. SE Assoc. Game and Fish Comm. 29:609-616. 
Showalter, C. R. 2000. The relationships between snags and cavity-nesting birds in a gypsy moth impacted forest. Thesis, West Virginia University, Morgantown, West Virginia, USA.

Sedgwick, J. A., and F. L. Knopf. 1986. Cavity-nesting birds and the cavity-tree resource in plains cottonwood bottomlands. J. Wildl. Manage. 50:247-252.

Stephenson, S. L. 1993. Upland forest vegetation. Pages 11-34 in Upland forests of West Virginia. Stephenson, S. L. (ed.). McClain Printing Company, Parsons, West Virginia.

, S. L., and H. S. Adams. 1993. Threats to the Upland Forests. Pages 261-273 in Upland forests of West Virginia. Stephenson, S. L., (ed.). McClain Printing Company, Parsons, West Virginia.

Stribling, H. L. 1990. Bird community response to timber stand improvement and snag retention. N. J. Appl. For. 7:35-38.

Thomas, J. W., R. G. Anderson, C. Maser, and E. L. Bull. 1979. Snags. Pages 60-77 in Wildlife habitats in managed forests of the blue mountains of Oregon and Washington. Thomas, J. W. (ed.). USDA Agric. Hand. 553.

Tubbs, C. H., and D. R. Houston. 1990. Fagus grandifolia Ehrh. American beech. pp. 325-332 in Silvics of North America. Vol. 2. Hardwoods. Burns, R. M., Honkala, B. H. (tech. coords). USDA Agric. Handb. 654. Washington, D.C.

Van Balen, J. H., C. J. H. Booy, J. A. Franeker, and E. R. Osieck. 1982. Studies on holenesting birds in natural nest sites 1 . Availability and occupation of natural nest sites. Ardea 70:1-24.

von Haartman, L. 1957. Adaptation in hole-nesting birds. Evol. 11:339-347. 
Walters, R. S., and H. W. Yawney. Acer rubrum L. red maple. pp. 60 - 69 in Silvics of North America. Vol. 2. Hardwoods. Burns, R. M., Honkala, B. H. (tech. coords). USDA Agric. Handb. 654. Washington, D.C.

Waters, J. R., B. R. Noon, and J. Verner. 1990. Lack of nest site limitation in a cavitynesting bird community. J. Wildl. Manage. 54:239-245.

West Virginia Natural Resources Analysis Center. 2001. http://www.nrac.wvu.edu.

Zar, J. H. 1999. Biostatistical Analysis. Fourth Edition. Prentice Hall, Upper Saddle River, New Jersey, USA. 916 p.

Zarnowitz, J. E., and D. A. Manuwal. 1985. The effects of forest management on cavitynesting birds in northwestern Washington. J. Wildl. Manage. 49:255-263. 
TABLE 1. Decay class stages of standing tree stems. ${ }^{a}$

\begin{tabular}{cl}
\hline Stage & \multicolumn{1}{c}{ Decay state $^{\mathrm{b}}$} \\
\hline 1 & Live, healthy tree. \\
2 & Declining, suppressed or dying tree. \\
3 & Dead tree, hard wood, most branches and twigs intact. \\
4 & Dead, loose bark, hard wood, many branches gone. \\
5 & Dead, softer wood, most bark and branches gone. \\
6 & Dead, soft wood, no bark, broken bole. \\
7 & Dead, moist decomposed wood, broken bole. \\
\hline
\end{tabular}

${ }^{\mathrm{a}}$ Maser et al. (1979).

${ }^{\mathrm{b}}$ General guidelines, conditions will vary with species. 
TABLE 2. Comparisons of plot characteristics among forest cover types, Monongahela National Forest, West Virginia, 1999-2001. ${ }^{a}$

\begin{tabular}{|c|c|c|c|c|c|c|}
\hline \multirow[b]{3}{*}{ Characteristic } & \multicolumn{6}{|c|}{ Forest Cover Type } \\
\hline & \multicolumn{2}{|c|}{$\mathrm{RS}-\mathrm{YB}$} & \multicolumn{2}{|c|}{$\mathrm{BC}-\mathrm{M}$} & \multicolumn{2}{|c|}{ WO - BO - NRO } \\
\hline & $\bar{x}$ & SE & $\bar{x}$ & SE & $\bar{x}$ & SE \\
\hline Age (yr) & 113.60 & 4.35 & 98.20 & 2.06 & 97.30 & 1.28 \\
\hline Basal Area $\left(\mathrm{m}^{2} / \mathrm{ha}\right)$ & 26.86 & 1.82 & 27.55 & 1.66 & 26.44 & 1.37 \\
\hline Tree Counts (stems/plot) & 80.92 & 8.64 & 55.16 & 4.85 & 67.30 & 6.63 \\
\hline DBH & 32.59 & 1.08 & 39.85 & 1.51 & 37.31 & 1.56 \\
\hline Slope (\%) & 20.76 & 2.88 & 23.04 & 1.87 & 28.80 & 3.65 \\
\hline Elevation (m) & 1120.32 & 19.79 & 1039.48 & 17.74 & 1022.96 & 24.85 \\
\hline Overstory cover (\%) & 72.24 & 2.93 & 75.12 & 2.32 & 81.96 & 1.80 \\
\hline Understory cover (\%) & 48.12 & 3.75 & 56.28 & 4.20 & 52.12 & 4.12 \\
\hline Shrub cover $(\%)$ & 70.00 & 4.39 & 36.24 & 5.33 & 34.08 & 4.28 \\
\hline Max. daily temp $\left({ }^{\circ} \mathrm{C}\right)^{\mathrm{b}}$ & 12.38 & 0.11 & 12.98 & 0.10 & 13.81 & 0.17 \\
\hline Min. daily temp $\left({ }^{\circ} \mathrm{C}\right)^{\mathrm{b}}$ & 2.47 & 0.03 & 2.56 & 0.02 & 2.70 & 0.02 \\
\hline Precipitation (cm/yr) & 141.74 & 0.83 & 136.88 & 0.80 & 130.14 & 1.52 \\
\hline
\end{tabular}

${ }^{\mathrm{a}}$ Data are means (and standard errors) for all plots ( $n=25$ for each type).

${ }^{\mathrm{b}}$ Mean annual measurement. 
TABLE 3. Log-likelihood comparisons of cavity occurrence among tree species occupying at least 3\% of all cavity-tree stems or $3 \%$ of all plot inventory stems, Monongahela National Forest, West Virginia, 1999 - 2001. The table shows G values of $2 \times 2$ tests between the listed species and the next species listed. Subsequent $G$ values are results from further $2 \times 2$ tests to differentiate all species when adjacent species are not significantly different at chi ${ }^{2} 0.05=3.841$. Species with the same letters indicate no significant difference between them.

\begin{tabular}{|c|c|c|c|c|c|c|c|}
\hline \multicolumn{4}{|c|}{ All Cavities } & \multicolumn{4}{|c|}{ Excavated Cavities Only } \\
\hline$\%^{\mathrm{a}}$ & Species $^{\mathrm{b}}$ & $G$ values & Mean Separartion & $\%^{\mathrm{a}}$ & Species $^{\mathrm{b}}$ & $G$ values & Mean Separation \\
\hline 23.67 & BLLO & 23.868 & $\mathrm{~A}$ & 14.49 & BLLO & 22.339 & $\mathrm{~A}$ \\
\hline 11.55 & AMBE & 4.760 & B & 5.46 & AMBE & 12.618 & $\mathrm{~B}$ \\
\hline 8.73 & SUMA & $2.338,3.919$ & $\mathrm{C}$ & 2.53 & SUMA & $0.195,0.422,11.909$ & $\mathrm{C}$ \\
\hline 6.92 & CHEO & $0.591,6.051$ & $\mathrm{CD}$ & 2.23 & CHEO & $0.012,7.090$ & $\mathrm{C}$ \\
\hline 5.81 & BLOA & $1.047,1.222,7.670$ & $\mathrm{DE}$ & 5.81 & YEBI & 9.418 & $\mathrm{C}$ \\
\hline 4.61 & YEBI & $0.099,7.590$ & $\mathrm{E}$ & 2.17 & RESP & $0.099,1.247,1.215$ & $\mathrm{D}$ \\
\hline 4.31 & WHOA & $2.606,3.528,14.039$ & $\mathrm{EF}$ & 0.94 & NROA & 0.096 & $\mathrm{D}$ \\
\hline 2.97 & REMA & $0.280,9.289$ & FG & 0.72 & REMA & 0.015 & $\mathrm{D}$ \\
\hline 2.68 & NROA & 5.126 & $\mathrm{G}$ & 0.64 & $\mathrm{BLCH}$ & & $\mathrm{D}$ \\
\hline 1.48 & BLCH & 0.982 & $\mathrm{H}$ & & & & \\
\hline 1.10 & RESP & & $\mathrm{H}$ & & & & \\
\hline
\end{tabular}

${ }^{\mathrm{a}}$ Percent of all cavity stems comprised by the listed species.

${ }^{\mathrm{b}} \mathrm{AMBE}=$ American beech, $\mathrm{BLCH}=$ black cherry, $\mathrm{BLLO}=$ black locust, BLOA = black oak, $\mathrm{CHEO}=$ chestnut oak, $\mathrm{NROA}=$ northern red oak, REMA = red maple, RESP = red spruce, $\mathrm{SUMA}=$ sugar maple, $\mathrm{YEBI}=$ yellow birch, and WHOA = white oak. 
TABLE 4. Comparisons between mean cavity tree and inventory tree diameters (DBH), paired by plot, Monongahela National Forest, West Virginia, 1999 - 2001.

\begin{tabular}{|c|c|c|c|c|c|c|c|}
\hline \multirow[b]{3}{*}{ Species $^{\mathrm{a}}$} & \multirow[b]{3}{*}{$n^{\mathrm{b}}$} & \multicolumn{4}{|c|}{ Mean DBH $(\mathrm{cm})$} & \multirow[b]{3}{*}{$t^{d}$} & \multirow[b]{3}{*}{$P$} \\
\hline & & \multicolumn{2}{|c|}{ Cavity trees } & \multicolumn{2}{|c|}{ Inventory Trees $^{\mathrm{c}}$} & & \\
\hline & & $\bar{x}$ & SE & $\overline{\mathrm{x}}$ & SE & & \\
\hline American beech & 16 & 36.69 & 2.67 & 23.58 & 3.04 & -3.98 & 0.0004 \\
\hline Black cherry & 11 & 45.52 & 5.67 & 44.38 & 2.98 & -0.18 & 0.8612 \\
\hline Chestnut oak & 13 & 52.94 & 4.40 & 35.51 & 4.49 & -2.77 & 0.0106 \\
\hline Northern red oak & 15 & 54.39 & 3.54 & 38.38 & 4.97 & -2.62 & 0.0145 \\
\hline Red maple & 26 & 31.91 & 2.57 & 22.49 & 1.99 & -2.90 & 0.0057 \\
\hline Red spruce & 14 & 32.86 & 2.55 & 30.71 & 2.52 & -0.60 & 0.5540 \\
\hline Sugar maple & 21 & 47.80 & 3.23 & 34.92 & 2.61 & -3.10 & 0.0036 \\
\hline White oak & 11 & 50.09 & 5.08 & 38.43 & 5.08 & -1.62 & 0.1205 \\
\hline Yellow birch & 26 & 38.98 & 2.52 & 22.88 & 1.40 & -5.58 & $<0.0001$ \\
\hline
\end{tabular}

${ }^{\mathrm{b}}$ Number of plots with cavity and inventory trees for comparison.

${ }^{\mathrm{c}}$ Trees tallied in prism counts.

${ }^{\mathrm{d}}$ Paired $t$ statistic for $\alpha=0.05$. 
TABLE 5. Comparisons between mean cavity tree height $(m)$ and inventory tree heights, paired by plot, Monongahela National Forest, West Virginia, 1999 - 2001.

\begin{tabular}{lccccccc}
\hline & & \multicolumn{7}{c}{ Cavity trees } & \multicolumn{2}{c}{ Inventory Trees $^{\mathrm{c}}$} & & \\
\cline { 3 - 6 } \multicolumn{1}{c}{ Species $^{\mathrm{a}}$} & $n^{\mathrm{b}}$ & $\overline{\mathrm{x}}$ & $\mathrm{SE}$ & $\overline{\mathrm{x}}$ & $\mathrm{SE}$ & $t^{d}$ & $P$ \\
\hline American beech & 16 & 16.77 & 1.46 & 16.55 & 1.36 & -0.09 & 0.9311 \\
Black cherry & 11 & 30.04 & 2.80 & 33.85 & 2.80 & 0.96 & 0.3486 \\
Chestnut oak & 13 & 20.51 & 2.23 & 22.71 & 1.41 & 0.83 & 0.4152 \\
Northern red oak & 15 & 24.48 & 2.38 & 27.73 & 2.16 & 1.01 & 0.3210 \\
Red maple & 26 & 23.34 & 1.94 & 24.06 & 1.60 & 0.28 & 0.7776 \\
Red spruce & 14 & 8.57 & 1.39 & 23.07 & 1.89 & 6.18 & $<0.0001$ \\
Sugar maple & 21 & 29.54 & 2.26 & 29.93 & 1.61 & 0.14 & 0.8915 \\
White oak & 11 & 24.62 & 3.41 & 25.83 & 2.76 & 0.28 & 0.7862 \\
Yellow birch & 26 & 19.68 & 1.64 & 19.69 & 1.50 & 0.00 & 0.9966 \\
\hline
\end{tabular}

${ }^{\mathrm{b}}$ Number of plots with cavity and inventory trees for comparison.

'Trees tallied in prism counts.

${ }^{\mathrm{d}}$ Paired $t$ statistic for $\mathrm{a}=0.05$. 
FIGURE 1. Plot locations in the Monongahela National Forest, West Virginia.

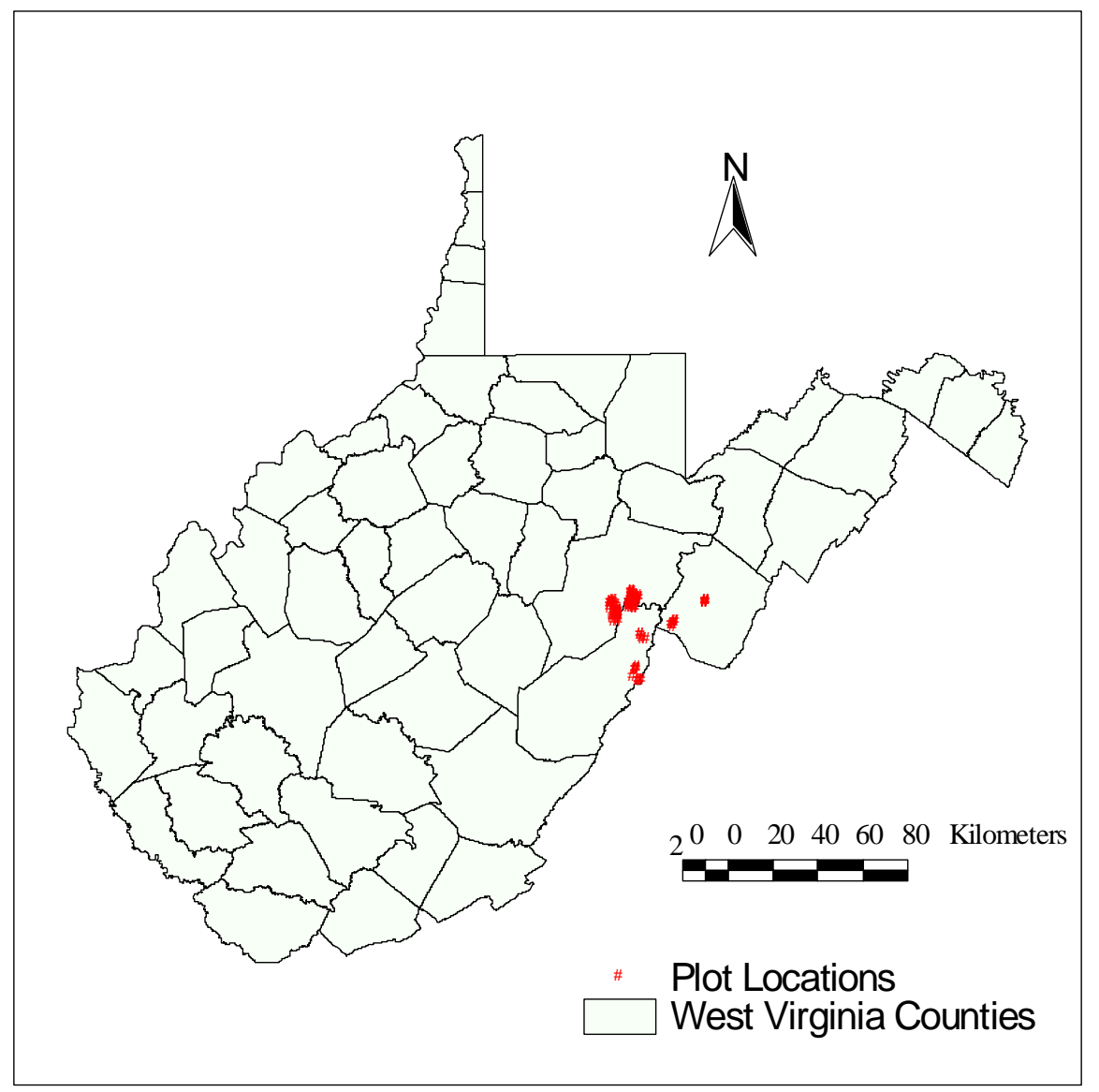


FIGURE 2. Percent of total basal area from prism tallies of $R S-Y B$ forest cover type, Monongahela National Forest, 1999 - 2001 (n=25). “OTHER” includes (in decreasing basal area) sugar maple, paper birch (Betula papyrifera), striped maple (Acer pensylvanicum), and sweet birch (Betula lenta).

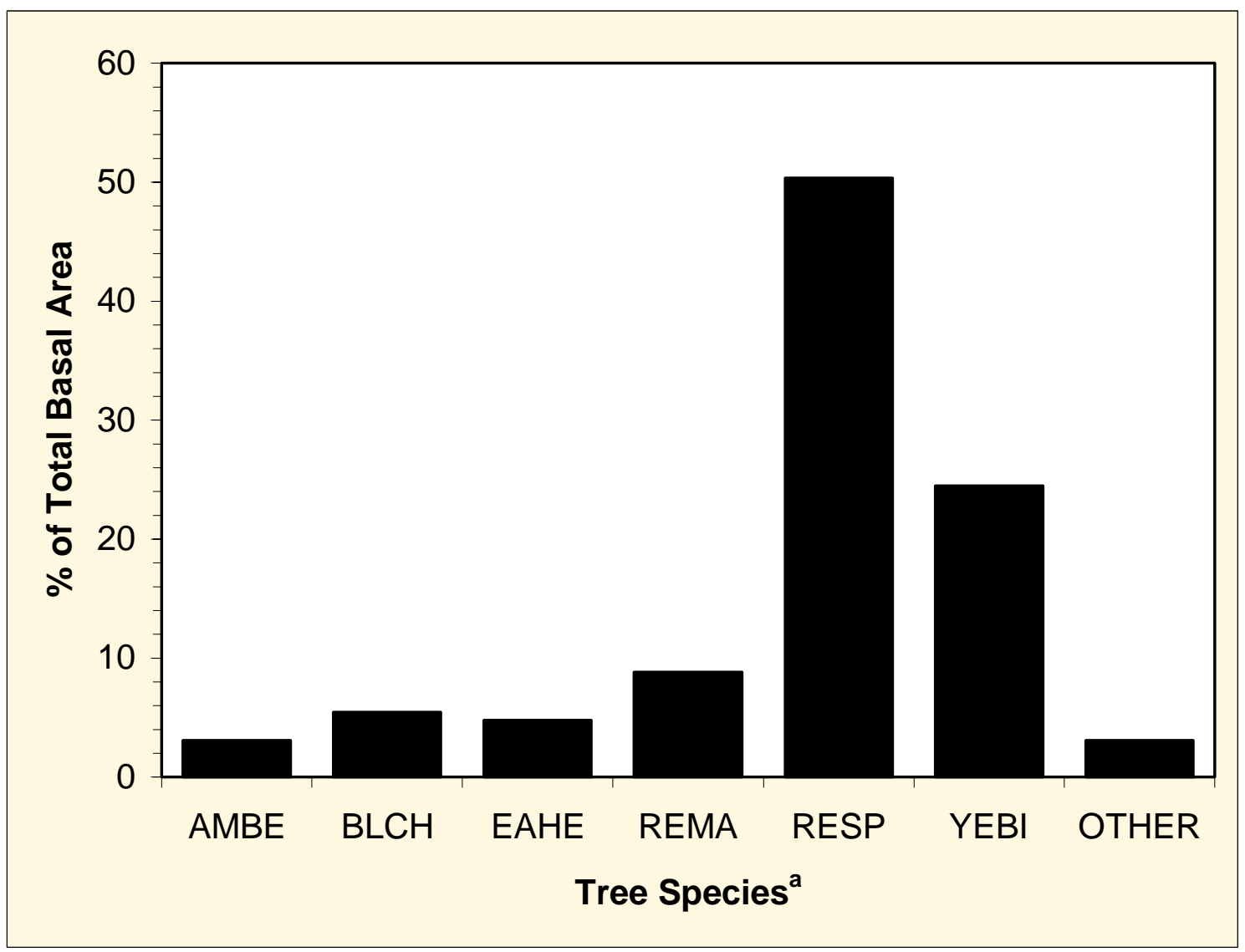

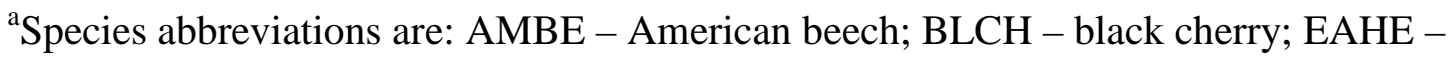
Eastern hemlock; REMA - red maple; RESP - red spruce; and YEBI - yellow birch. 
FIGURE 3. Percent of total stem counts per plot from prism tallies of RS-YB forest cover type, Monongahela National Forest, 1999 - 2001 (n=25). “OTHER” includes (in decreasing frequency) sugar maple, paper birch, striped maple, and sweet birch.

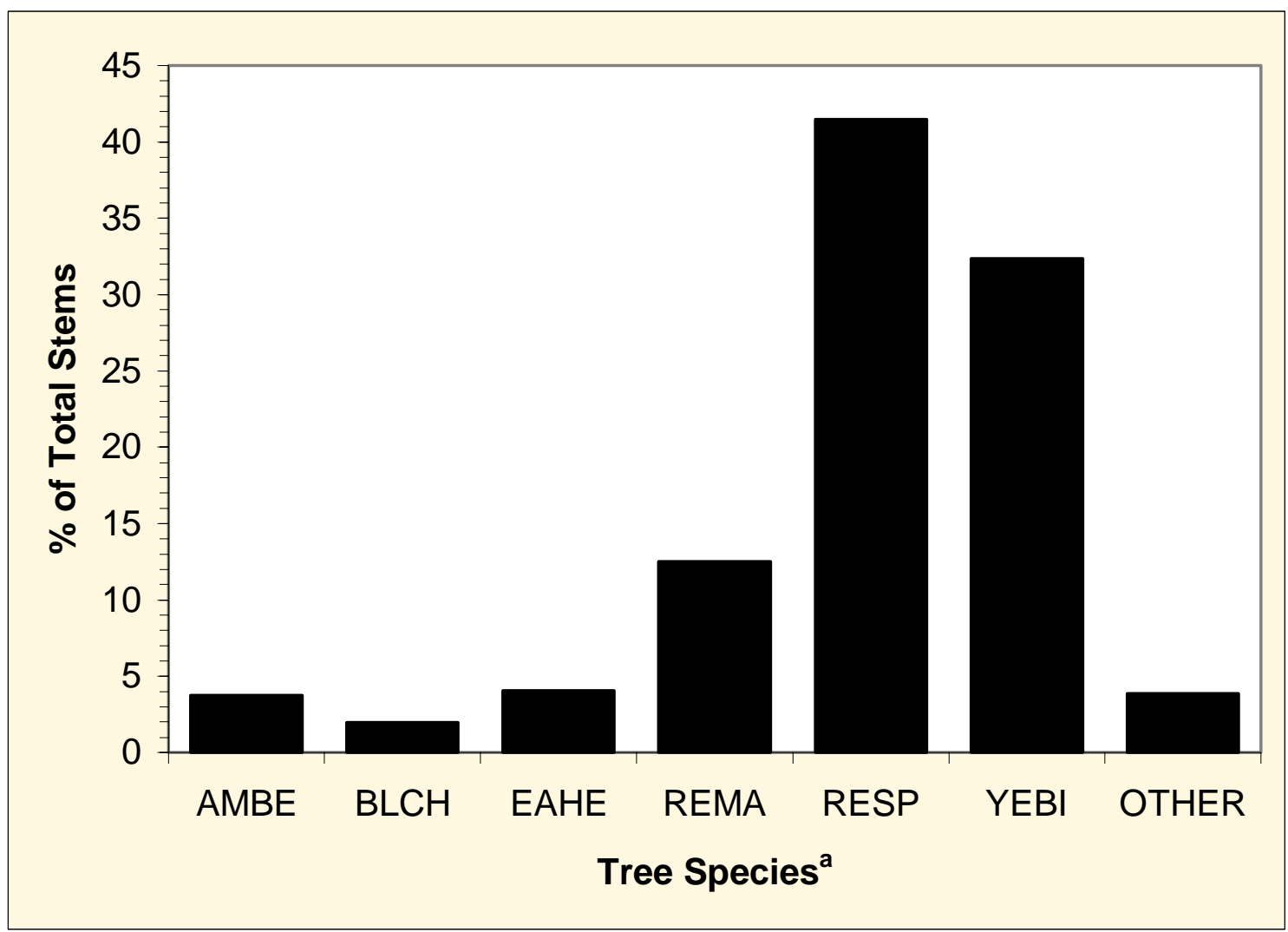

${ }^{\mathrm{a}}$ Species abbreviations are: AMBE - American beech; BLCH - black cherry; EAHE Eastern hemlock; REMA - red maple; RESP - red spruce; and YEBI - yellow birch. 
FIGURE 4. Percent of total basal area from prism tallies of BC-M forest cover type,

Monongahela National Forest, 1999 - 2001 (n=25). “OTHER” includes (in decreasing basal area) sweet birch, cucumbertree (Magnolia acuminata), eastern hemlock, n. red oak, red spruce, serviceberry (Amelanchier spp.), unknown stems, shagbark hickory (Carya ovata), slippery elm (Ulmus rubra), and striped maple.

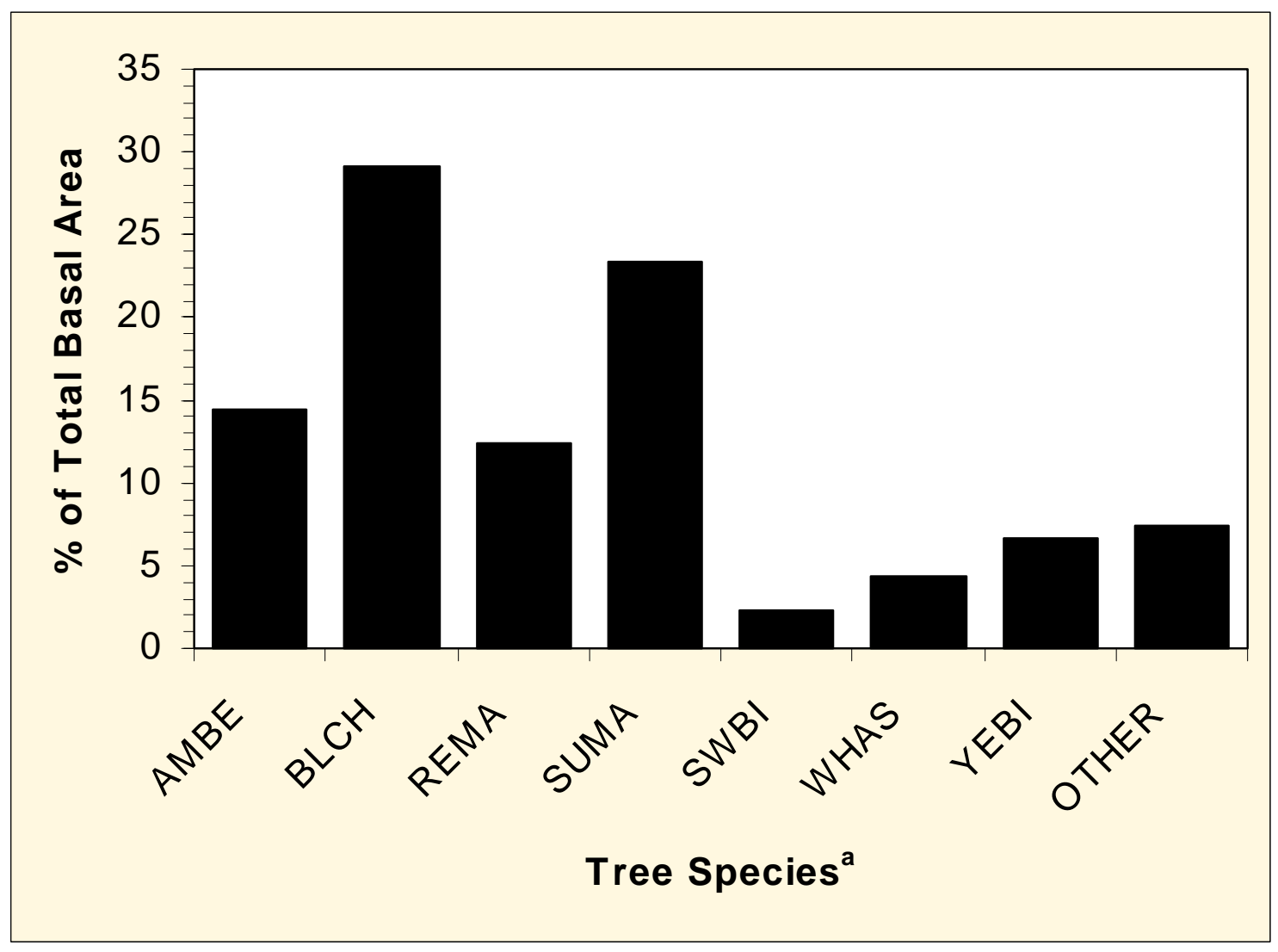

${ }^{\mathrm{a}}$ Species abbreviations are: AMBE - American beech; BLCH - black cherry; REMA red maple; SUMA - sugar maple; WHAS - white ash; and YEBI - yellow birch. 
FIGURE 5. Percent of total stem counts per plot (0.78 ha) composition from prism tallies of BC-M forest cover type, Monongahela National Forest, $1999-2001(n=25)$. “OTHER” includes (in decreasing frequency) sweet birch, cucumbertree, eastern hemlock, n. red oak, red spruce, serviceberry, shagbark hickory, slippery elm, striped maple, and 'unknown' stems.

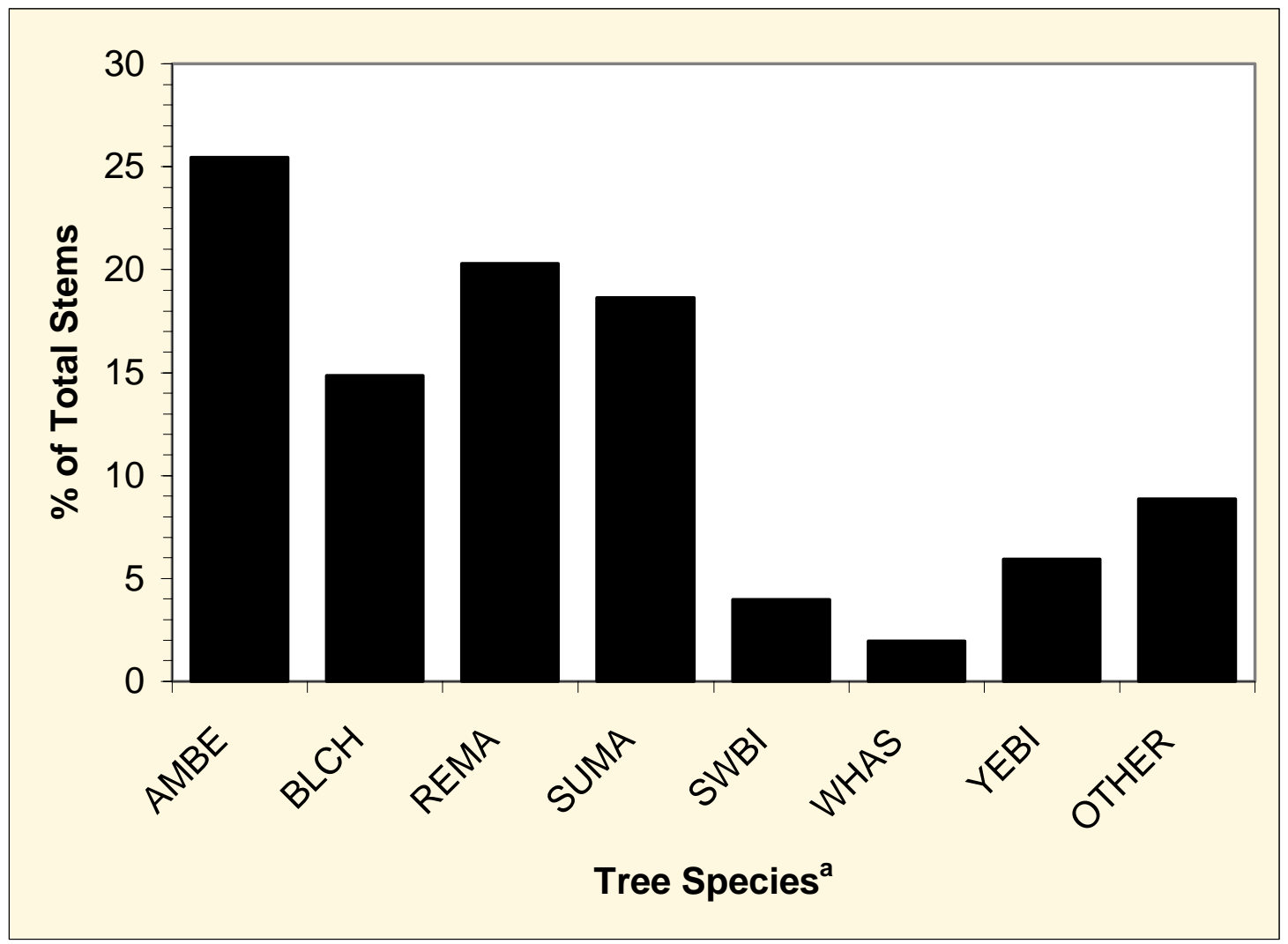

${ }^{\mathrm{a}}$ Species abbreviations are: AMBE - American beech; BLCH - black cherry; REMA red maple; SUMA - sugar maple; WHAS - white ash; and YEBI - yellow birch. 
FIGURE 6. Percent of total basal area from prism tallies of $W O-B O-N R O$ forest cover type, Monongahela National Forest, 1999 - 2001 (n=25). “OTHER” includes (in decreasing basal area) scarlet oak, Am. Basswood (Tilia Americana), black cherry, red pine (Pinus resinosa), sugar maple, white ash, Am. beech, black gum (Nyssa sylvatica) sweet birch, bigtooth aspen (Populus grandidentata), sassafras (Sassafras albidum), sweet birch, and 'unknown' stems.

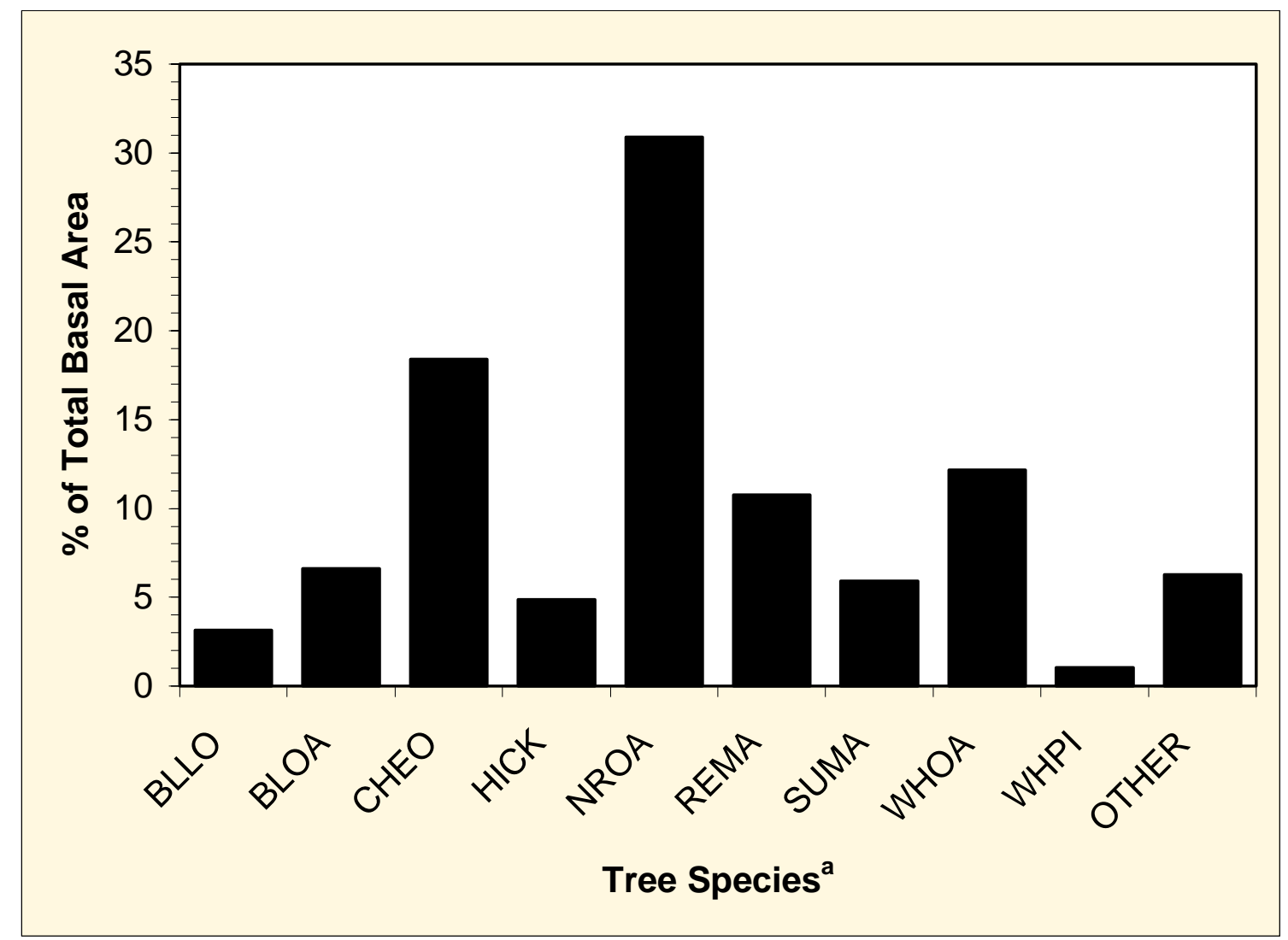

${ }^{\mathrm{a}}$ Species abbreviations are: BLLO - black locust; BLOA - black and scarlet oaks; CHEO - chestnut oak; HICK - all Carya spp.; NROA - Northern red oak; REMA - red maple; SUMA - sugar maple; WHPI - white pine; and WHOA - white oak. 
FIGURE 7. Mean stem counts per plot $(0.78 \mathrm{ha})$ composition from prism tallies of WOBO - NRO forest cover type, Monongahela National Forest, $1999-2001(n=25)$.

“OTHER” includes (in decreasing frequency) scarlet oak, Am. Basswood, shagbark hickory, white pine, black cherry, red pine, sugar maple, white ash, Am. beech, black gum, sweet birch, bigtooth aspen, pignut hickory, sassafras, sweet birch, and 'unknown' stems.

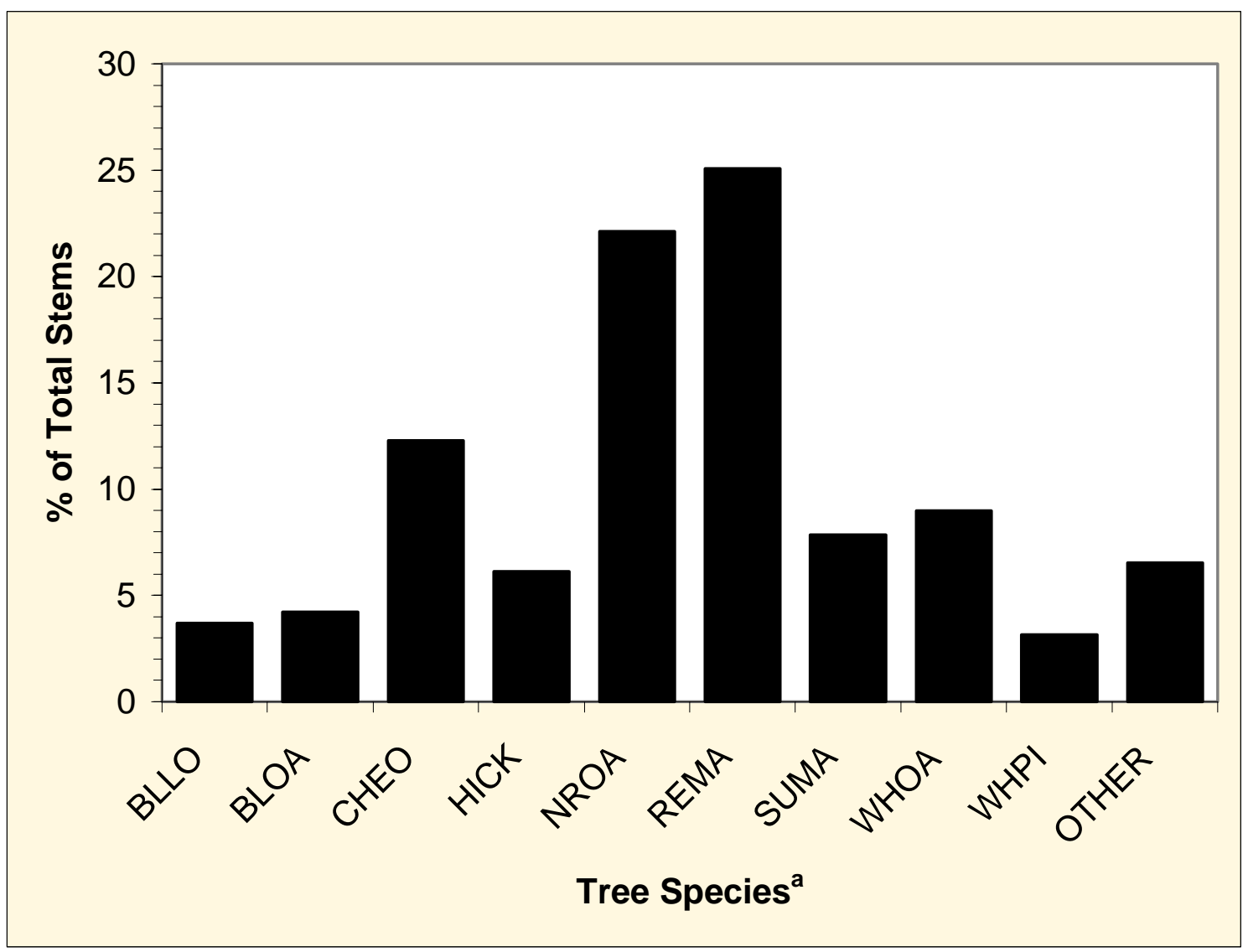

${ }^{\mathrm{a}}$ Species abbreviations are: BLLO - black locust; BLOA - black and scarlet oaks; CHEO - chestnut oak; HICK - all Carya spp.; NROA - Northern red oak; REMA - red maple; SUMA - sugar maple; WHPI - white pine; and WHOA - white oak. 
FIGURE 8. Number of cavity trees showing excavated cavities by species among all plots $(N=75)$. “OTHERS” include (in decreasing frequency) unknown stems, cucumbertree, sweet birch, red pine, Am. basswood, black gum, serviceberry, Fraser magnolia (Magnolia fraseri), bigtooth aspen, white ash, and slippery elm. Carya spp. includes mockernut, pignut, and shagbark hickories.

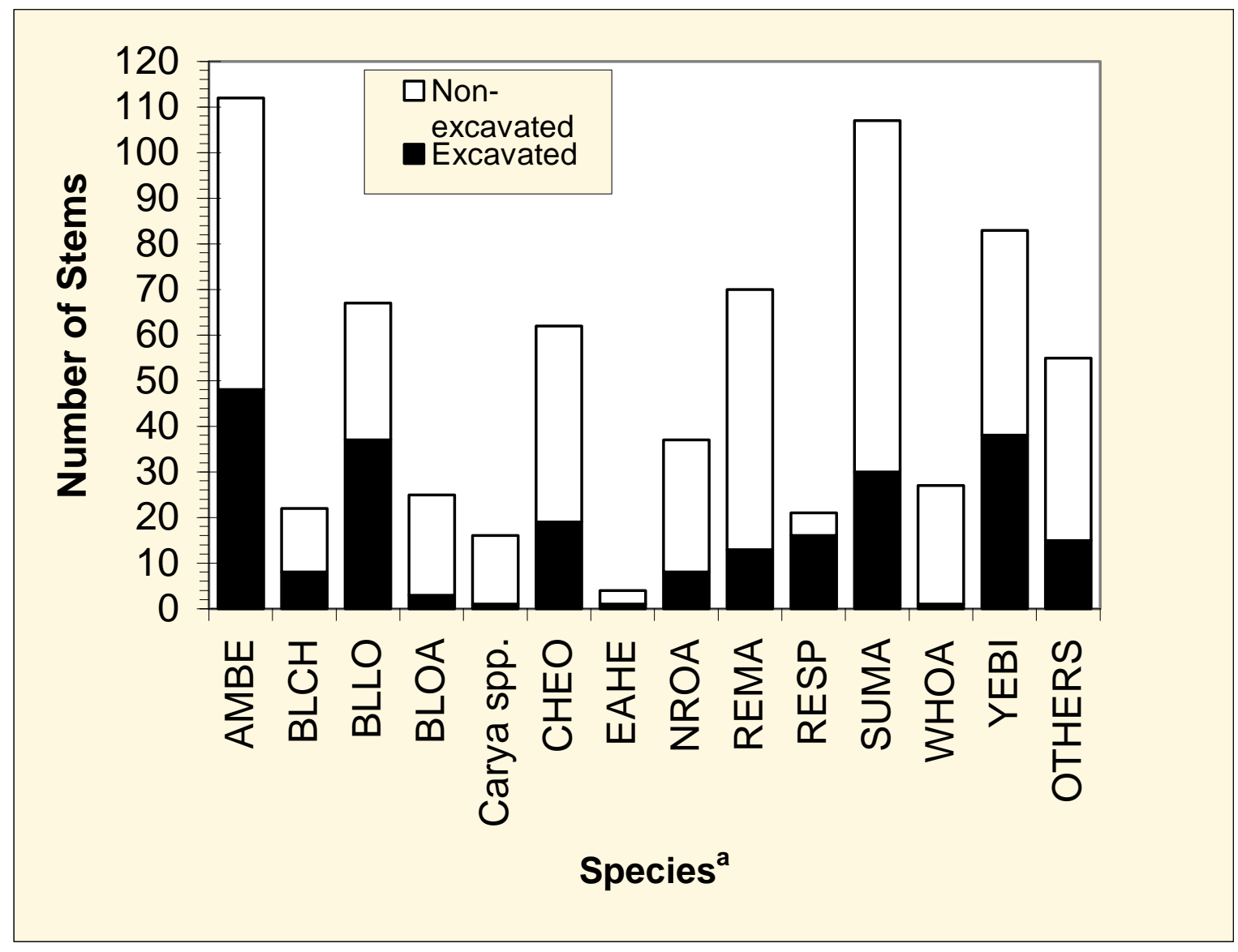

${ }^{\mathrm{a}}$ Species codes are as follows: AMBE - American beech; BLCH - black cherry; BLLO black locust; BLOA - black oak; CHEO - chestnut oak; EAHE - Eastern hemlock; NROA - Northern red oak; REMA - red maple; RESP - red spruce; SUMA - sugar maple; WHOA - white oak; and YEBI - yellow birch. 
FIGURE 9. Number of cavity trees and non-cavity trees ${ }^{a}$ by species among all plots $(N=75)$. “OTHERS" include (in decreasing overall frequency) white ash, sweet birch, Am. basswood, cucumbertree, red pine, serviceberry, unknown stems, bigtooth aspen, black gum, Fraser magnolia, and slippery elm. Carya spp. includes mockernut, pignut, and shagbark hickories.

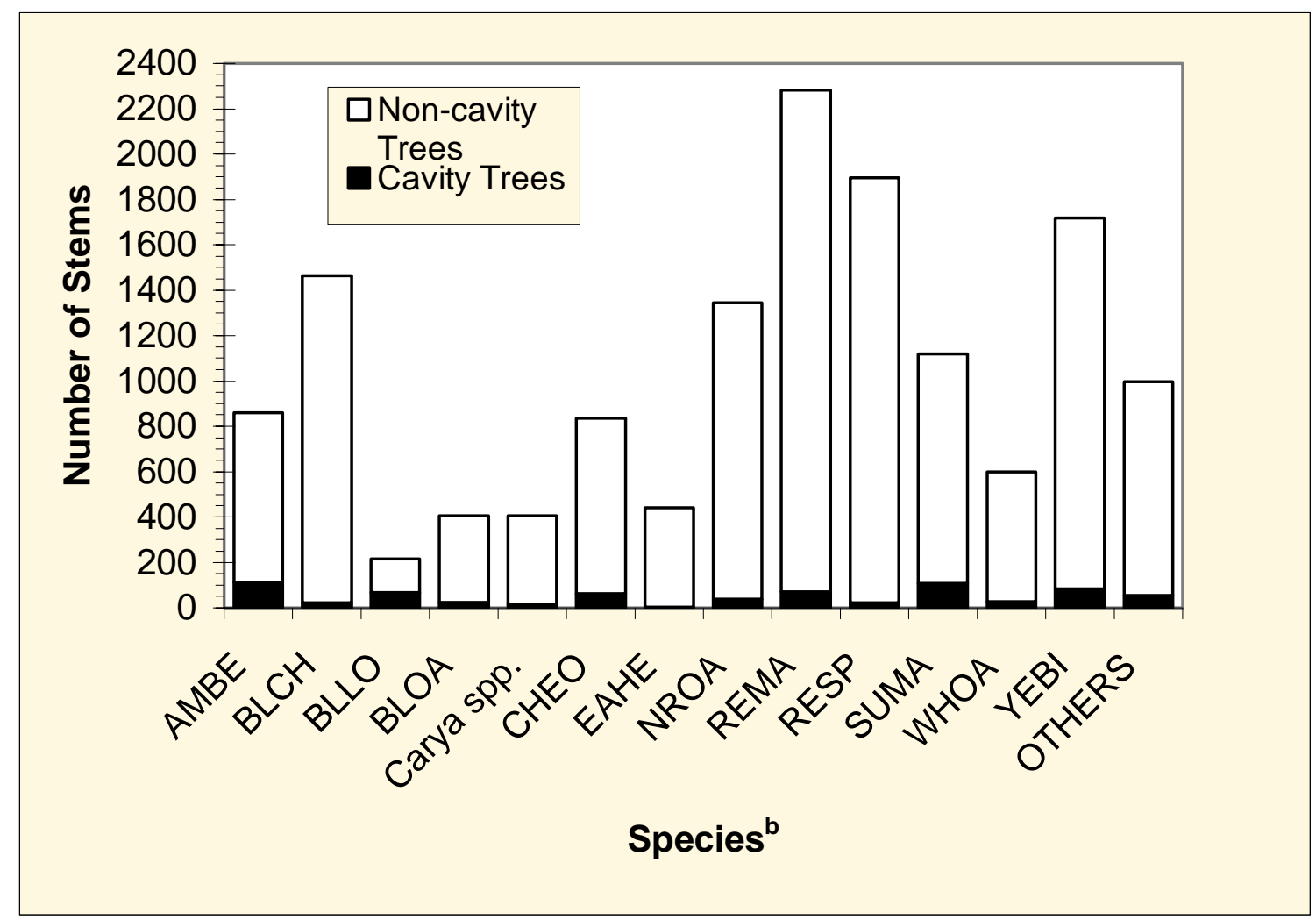

${ }^{a}$ Non-cavity trees estimated from prism tally information.

${ }^{\mathrm{b}} \mathrm{See}$ Table 2 for species codes. 


\title{
CHAPTER 3
}

\section{FACTORS INFLUENCING AVIAN COMMUNITIES AMONG BOREAL, NORTHERN HARDWOOD, AND CENTRAL HARDWOOD FOREST COVER TYPES IN THE SOUTHERN ALLEGHENY MOUNTAINS}

\begin{abstract}
Insular effects may influence biodiversity among boreal and northern hardwood forest cover types of the southern Allegheny Mountains. These differences may be due to natural characteristics, such as marked topography and an elevational gradient, as well as from past influences, such as poor logging practices. Because of their dependency, cavity-nesting species may be especially vulnerable to changes in forest structure and composition. Analyses among a central hardwood (white oak - black oak northern red oak), northern hardwood (black cherry - maple), and boreal (red spruce yellow birch) forest type show no differences in avian species diversity, richness, or overall density, yet avian community composition varied among the 3 forest types. Cavity-nesting species dependent on available tree holes were found most in white oak black oak - northern red oak plots, which also contained significantly more available cavities than other forest types $(p=0.009)$. Basal area was a consistent covariate among analyses of diversity richness, and density. Besides forest acreage and composition, vertical structure is likely the third major influence on avian community compositions. Future management decisions for biodiversity should consider understory and shrub layers as well as forest overstory composition.
\end{abstract}

This chapter in the style of Conservation Biology. 


\section{INTRODUCTION}

Habitat fragmentation is considered a main factor in the loss of forest biodiversity (Hagan et al. 1995; Villard et al. 1999; Manolis et al. 2000). Not only have wildlife population declines been attributed to direct losses of suitable habitat, but isolation effects (i.e., habitat configuration) and increased amounts of habitat edges also have negatively affected population levels (Hagan et al. 1995; Villard et al. 1999). Poor timber harvesting practices of the past, such as those throughout the late 1800 s in the southern Allegheny Mountains of West Virginia (Clarkson 1993), are often cited as causes of forest fragmentation. Additionally, incipient harvesting and fragmentation affect wildlife population levels quite differently from residual and historical causes (Hagan et al. 1995). Thus, baseline information on wildlife population levels among the various forest cover types is necessary to evaluate effects of current forest management.

Generally, the Allegheny Mountains are considered within the central hardwoods region, yet northern hardwood and boreal forest types also can be found within the immediate area (Eyre, 1980; Hicks 1998). The physiographic Allegheny Mountain section of the Appalachian Plateau runs southwesterly from central Pennsylvania to the highest peaks of West Virginia (Fenneman 1938). At the highest elevations of the Allegheny Mountains in West Virginia, generally above 1000 meters, relict patches of boreal forests remain from cooler, periglacial times (Lesser 1993). Moving down in elevation, forests become a mosaic between higher, north-facing northern hardwood types and lower, south-facing central hardwood stands (Hicks 1998). 
Past management influences on forests also are usually manifested in present forest stands. In West Virginia, for example, valley forests were cleared to establish farmsteads, and red spruce tracts at higher elevations were girdled and burned to produce cattle pastures and later logged for timber (Clarkson 1993; Stephenson and Adams 1993). Removal of the timber has left mostly a mosaic of 2nd and 3rd-growth forests (Stephenson 1993). Preferential harvesting and introduced diseases and pests also have changed stand composition over time (Carvell 1986; Acciavatti et al. 1993). These past effects, as well as others, influence the continuity of apparently contiguous wildlife habitats.

Furthermore, since the 1960s, evidence shows that boreal forests of North America are puzzlingly shrinking in area, mainly due to increasing mortality rates of red spruce (Picea rubens) and balsam fir (Abies balsamea) at higher elevations (Stephenson and Adams 1993). Not only are numerous bird species of the Allegheny Mountains limited in breeding to the boreal forests (Hall 1983), but the entire populations of the federally endangered Virginia northern flying squirrel (Glaucomys sabrinus fuscus) and Cheat Mountain salamander (Plethodon nettingi) are within these relict spruce forest patches (Green and Pauley 1987; Odom et al. 2001).

Island biogeography presumes that the number of species inhabiting an island is inversely proportional to the distance of the island from the mainland (MacArthur and Wilson 1967, Davidar et al. 2001). This premise also may hold true concerning the number of avian species breeding in the boreal and northern hardwood forest cover types of the southern Allegheny Mountains region (Hall 1983). For examples, the boreal spruce and northern hardwood forest patches of West Virginia provide breeding 'islands' 
to many bird species, including the yellow-bellied sapsucker (Sphyrapicus auratus), redbreasted nuthatch (Sitta canadensis), black-capped chickadee (Poecile atricapilla), and black-throated blue warbler (Dendroica caerulescens) (Hall 1983). Furthermore, these northern forest cover patches are non-contiguous and at the southern limit of breeding ranges for numerous bird species, including the alder flycatcher (Empidonax alnorum), Swainson's thrush (Catharus ustulatus), hermit thrush (Catharus guttatus), magnolia warbler (D. magnolia), northern waterthrush (Seirus noveboracensis), and purple finch (Carpodacus purpureus) (Hall 1983). Thus, isolation effects similar to those incurred from forest fragmentation effects are induced upon breeding birds of northern forest cover within the southern Allegheny Mountains region.

Although habitat requirements differ for each wildlife species, diversity and abundances of some species guilds, such as cavity-using wildlife, are suitable indicators of forest health trends (Carey 1983). Primary users (e.g., woodpeckers) excavate their own cavities, and true secondary cavity-using species rely on available holes for nesting (Martin and Eadie 1999). Weak excavators (e.g., red-breasted nuthatch, black-capped chickadee) use cavities made by primary excavators, yet also excavate nest sites if soft wood is available (Martin and Eadie 1999).

Furthermore, concerns about possible negative impacts of forest histories on cavity-tree resources have led to numerous publications relating cavity tree abundances to forest characteristics (i.e., cover types, stand features) and at times management practices (Newton 1994). Effects of fragmentation are readily apparent in many of these and other studies as well. For example, although recently clearcut areas in the Jefferson National Forest of southwest Virginia attracted downy (Picoides pubescens) and hairy 
woodpeckers (Picoides villosus), 12-year-old stands remained virtually unused by these woodpeckers (Conner and Crawford 1974). Also, on timber stand improvement forest plots of central Pennsylvania, Stribling et al. (1990) found bird community richness and abundance significantly higher on plots with snags retained than on control plots. Similarly, even-aged plots with reserve trees in central Pennsylvania were used more often than traditional clearcut stands by several interior forest-associated bird species (Rodewald and Yahner 2000).

The Monongahela National Forest (MNF) of West Virginia was formed to protect the forest resources in the southern Allegheny Mountains (Clarkson 1993), thus providing an excellent resource for monitoring wildlife population trends. My objectives were to: 1) compare breeding bird diversity, richness, and density among central hardwood, northern hardwood, and boreal forest cover, 2) analyze avian community compositions among the 3 forest categories, 3) compare cavity-using bird diversity, richness, and density among the 3 forest categories, 4) analyze relationships between secondary-cavity using birds (i.e., birds dependent on available cavities) and tree cavities among the 3 forest categories, and 5) develop management recommendations for the MNF. For purposes here, weak excavating species are included in the secondary cavity-using guild.

\section{STUDY AREA}

The study was conducted on the Potomac and Greenbrier Ranger Districts of the MNF, in Pendleton, Pocahontas, and Randolph Counties, West Virginia. More than $80 \%$ of 
Randolph and Pocahontas Counties are forested, whereas wider valleys in Pendleton County account for slightly more farmland and less forest (Buckelew and Hall 1994). Plots were divided evenly among 3 Society of American Foresters cover types in the southern Allegheny Mountains: white oak - black oak (Q. velutina) - northern red oak (Q. rubra) (WO - BO - NRO), which includes the sub-type scarlet oak $(Q$. coccinea $)-$ chestnut oak; black cherry - maple (BC - M); and red spruce - yellow birch (RS YB)(Eyre 1980). These types represent central hardwood, northern hardwood, and boreal forests, respectively.

All study plots were within $27 \mathrm{~km}(16.8 \mathrm{mi})$ of a geographic center near Lost Run in Highland County, Virginia, which is about $11.8 \mathrm{~km}(7.3 \mathrm{mi})$ east of the Greenbrier District Ranger Station in Bartow, West Virginia. Elevation ranged from about $540 \mathrm{~m}$ $(1772 \mathrm{ft})$ to $1481 \mathrm{~m}(4861 \mathrm{ft})$. However, relief usually ranges between $300 \mathrm{~m}(1000 \mathrm{ft})$ and $500 \mathrm{~m}(1600 \mathrm{ft})$ (Hall 1983). The terrain is hill-and-valley with some slopes near 70 $\%$ grade (Pyle 1982).

Prevailing winds come from the west, creating the greatest amounts of precipitation along the upper-west slopes and a rain-shadow effect along east slopes (Buckelew and Hall 1994). Annual precipitation ranges from $94-132 \mathrm{~cm} / \mathrm{yr}$ (Buckelew and Hall 1994). Average temperatures along the southern Allegheny Mountain ridgeline are $-8^{\circ} \mathrm{C}\left(18^{\circ} \mathrm{F}\right)$ in winter, and $19^{\circ} \mathrm{C}\left(66^{\circ} \mathrm{F}\right)$ in summer with a maximum of $24^{\circ} \mathrm{C}\left(76^{\circ} \mathrm{F}\right)$ (Estepp 1992). Study plots were located on 10 soil associations (Pyle 1982; Estepp 1992; Flegel 1999). Site indices typically range from 35 to 80, indicating the expected height of trees after 50 years growth (Pyle 1982; Estepp 1992; Flegel 1999). 


\section{METHODS}

\section{Forest Cover Types}

To analyze bird quantities among central hardwoods, northern hardwoods, and boreal forests of the southern Allegheny Mountains, I chose to focus on 1 SAF forest cover type in each general forest category so variations in stand compositions among categories could be minimized. I also used an arbitrary minimum stand age of 90 years so that only mature stands would be compared, yet a practical amount of usable stands would exist. I chose the white oak - black oak - northern red oak type (Quercus alba-Q. velutina - Q. rubra) as a central hardwood because each of these species is commercially important, most other central hardwood species are common associates. I also focused on black cherry - maple (Prunus serotina - Acer spp.) stands among northern hardwoods because of the current importance of black cherry veneer in timber markets. To reduce possible bias resulting from different species growth forms, I chose to focus on red spruce yellow birch (Betula alleghaniensis) rather than pure red spruce as a boreal forest cover type.

\section{Plot Establishment}

I randomly selected appropriate forest stands from a list of stands $\geq 90$ years in which to establish study plots. I avoided areas with recent or intense management activity, and areas more than $1200 \mathrm{~m}$ from a drivable road. Using compartment maps from the Forest 
Service, I selected a random distance and compass bearing from an access point to establish the center for each 50-m radius plot. Each plot was within 1 mapped stand, and plots were at least $250 \mathrm{~m}$ apart for independent sampling (Ralph et al. 1995). I set up 30 plots in each SAF cover type for a total of 90 plots. On 75 plots (25 in each forest type) I counted cavity trees. All plots were established when leaves were absent from trees to facilitate cavity searching.

\section{Plot Inventory and Cavity Search}

Center point slope and prevailing aspect were recorded (Marcot 1983; Marzluff and Lyon 1983). I determined plot elevations from a geographic information systems (GIS) analysis. More specifically, I placed center point location information on a digital elevation grid (with cell sizes of 90 m) of West Virginia using ArcView GIS software. Elevation values were downloaded from the West Virginia Natural Resources Analysis Center website (www.nrac.wvu.edu, December 12, 2001).

In summer months I estimated percent overstory cover (codominant and dominant canopy), understory cover ( $<2 \mathrm{~m}$ tall to overtopped canopy), and shrub cover ( $<2 \mathrm{~m}$ tall) at center points and estimates at 3 random equidistant points about $25 \mathrm{~m}$ from the plot center. Similar to the method developed by James and Shugart (1970), I estimated overstory, understory and shrub layer the percent of total cover of each vegetation layer in $10 \mathrm{~m}$ radius circles at each of the four points within the plot. I then averaged these readings for an overall plot estimation. 
I sampled center points via a prism with a basal-area factor of 10 to determine basal area and tree tallies within plots. For each tallied tree the species, diameter at $1.5 \mathrm{~m}$ (DBH), and height (determined with a clinometer) were recorded. Plot composition, basal area, and number of standing trees were estimated from prism-tally information (Avery and Burkhart 1997). In considering all secondary cavity-nesting species of interest, the smallest usable tree size listed by Degraaf and Shigo (1985) is a DBH of $10.15 \mathrm{~cm}$ (4 in) for black-capped chickadee nest cavities, so only trees $>10 \mathrm{~cm} \mathrm{DBH}$ were tallied.

With an assistant and binoculars, I counted all cavity trees by splitting plots into 6 "pie" sections lined by 50-m tapes and tagging each located tree. Harrison (1975) provides minimum average nest-cavity dimensions of $6 \mathrm{~cm}(23 / 8 \mathrm{in})$ diameter and about $12.7 \mathrm{~cm}$ (5 in) deep, with an opening of about $3.5 \mathrm{~cm}$ (1 3/8 in) (for black-capped chickadees). Therefore, cavities were counted when estimated to be at least $5 \mathrm{~cm}$ diameter by $10 \mathrm{~cm}$ deep with an opening $>3 \mathrm{~cm}$.

\section{Breeding Bird Counts}

I estimated bird quantities using a 50-m fixed radius point count method on all plots (Ralph et al. 1995). Thirty original plots (10 per forest type) were established and visited twice between 27 May and 2 July 2000, while all plots were twice counted between 26 May and 4 July 2001. Counts were 10 minutes and duration, and all sky and wind conditions were acceptable as per Ralph et al. (1995). Because squirrel populations also use tree cavity resources (Sanderson 1975; DeGraaf and Shigo 1985), red squirrels 
(Tamiasciuris hudsonicus), eastern gray squirrels (Sciuris carolinensis), and eastern chipmunks (Tamias striatus) also were tallied during bird counts. Plot information was pooled between visits but separated by year. For comparisons among forest types, all maximum yearly plot tallies were used in statistical analyses.

\section{Statistical Analyses}

Analyses focused on determining differences in species richness, densities, and diversity among the 3 forest cover types. Because within-year counts were not mutually independent, I calculated yearly richness and density for each plot by using the maximum species abundance values between the 2 yearly point counts (Nur et al. 1999). I used Shannon's Index to quantify yearly plot diversities (Nur et al. 1999). I similarly calculated species richness, plot density, and diversity values for totals of all cavity species, and secondary-using cavity species only.

Because of unequal plot sample sizes between years, data were analyzed by 2 principle methods to include information from all points in both years. First, between year data was tested using a nested analysis of variance (ANOVA) design; forest types were treatment groups, with 10 plots per treatment, and 2 replications per plot (Dowdy and Wearden 1991). Diversity, richness, and density were tested using the nested design for all counted species, then all cavity species, and lastly only secondary species.

Secondly, all 90 plots in 2001 were tested using an analysis of covariance (ANCOVA) (Dowdy and Wearden 1991). Because species diversity, richness, and densities may vary accordingly with other plot features (e.g., basal area, tree count, stand 
area), the suitability of each feature as a concomitant variable in ANCOVA regression models was tested in an additive, stepwise fashion (Dowdy and Wearden 1991). I fitted separate regression models in ANCOVAs for species diversity, richness, and plot densities for all counted wildlife species. I repeated the processes using only cavity-using species, and then only secondary-using species, to determine the dependent variable values for each plot.

I tested the equality of occurrence for guilds and species among the 3 forest types in $3 \times 2 \chi^{2}$ contingency tests (Dowdy and Wearden 1991; Zar 1999). Only species with expected frequencies (i.e., total number of observed frequencies/3 for each forest type) of >5 individuals/forest type were tested (Dowdy and Wearden 1991; Zar 1999). I used logistic regression models to determine if individual species presence on plots was significantly related to plot characteristics which included: basal area, stem density, overstory cover, understory cover, shrub cover, elevation, and basal areas and stem densities of the 8 most common tree species (Nur 1999). I used Hosmer and Lemeshow goodness-of-fit tests to measure model significance (Cody and Smith 1997).

Because only 75 plots (25 per forest type) were searched for cavities, cavity tree counts per plot were not used in ANCOVAs or logistic regressions. Instead, I tested the suitability of cavity tree counts as covariates for cavity-using wildlife values in additional regression models. I fitted regression models for the 75 plots as I did for all 90 plots - in an additive, stepwise fashion. I tested density values independently for each of the various guilds of cavity-using wildlife, disregarding forest cover types. I tested for significant relationships between individual cavity-using species and cavity tree 
abundances using logistic regressions (Nur 1999). As with wildlife species data, I used an ANCOVA to determine if cavity tree abundances differed among forest cover types.

To improve normality all percentage data (e.g., slope, overstory cover, understory cover) were arcsine transformed (Zar 1999). Other data were similarly treated using logarithmic transformations when Kolmogorov-Smirnov goodness of fit tests showed normality was thereby improved (Zar 1999). Richness and density values for cavityusing wildlife guilds were analyzed using a square-root transformation (Zar 1999). I used Tukey's test for multiple comparisons to separate means when significant differences among treatments were suggested (Dowdy and Wearden 1991; Zar 1999). All tests were significant if $P<0.05$.

\section{RESULTS}

A total of 60 wildlife species was tallied among the 3 forest cover types. Thirty-nine species were found in RS - YB plots, whereas 45 and 42 species were counted in $\mathrm{BC}-\mathrm{M}$ and WO - BO - NRO plots, respectively. The 2001 maximum tally of all species on all plots totaled 1154 animals; 443 were counted in RS - YB stands, 376 individuals in BC $\mathrm{M}$ stands, and 335 individuals in $\mathrm{WO}-\mathrm{BO}-\mathrm{NRO}$ stands. Using the maximum species abundance values between years for each plot, the maximum densities were 11.6 animals/ha/year in RS - YB plots, 9.8 animals/ha/year in BC - M stands, and 8.8 animals/ha/year in $\mathrm{WO}-\mathrm{BO}$ - NRO plots for all plots within types combined.

Twenty-eight species were recorded at least 15 times using maximum tallies at each plot for each species (Table 1). Only 6 of the 28 species showed equal occurrences 
among all forest cover types (Table 1). The most numerous species among all plots per breeding season were the red-eyed vireo (Vireo olivaceus) and black-throated green warbler (Dendroica virens), each recorded 60 times in 2001 (Fig. 1). Only the dark-eyed junco (Junco hyemalis) was found on all RS - YB plots. The red-eyed vireo was most widespread among $\mathrm{BC}-\mathrm{M}$ and $\mathrm{WO}-\mathrm{BO}-\mathrm{NRO}$ plots, occupying 28 and 24 of 30 plots, respectively. In contrast, the red-eyed vireo occupied only $10 \mathrm{RS}-\mathrm{YB}$ plots.

Logistic regression models explained the likelihood of occurrence of 13 bird species (Appendix VII). Both elevation and shrub cover (\%) varied positively with the presence of 3 species and varied negatively with the presence of 2 species. Among tree species, increased basal area per plot of yellow birch and sugar maple together increased the likelihood of occurrence of the Blackburnian warbler (Dendroica fusca), blackthroated blue warbler, and winter wren (Troglodytes troglodytes). Separately, yellow birch stem densities increased with the increased likelihood of 4 species, while sugar maple stem densities increased with the increased likelihood of 3 species.

Yearly maximum counts of cavity-using wildlife species for 2001 alone were equal among forest types; 117 were observed in RS - YB plots, 118 were observed in BC - M plots, and 116 were spotted in $\mathrm{WO}-\mathrm{BO}-\mathrm{NRO}$ plots $\left(\chi^{2}=0.017, \mathrm{df}=2, p=\right.$ 0.992). Secondary cavity using species accounted for 304 of the 351 total cavity-using species observed; 105 were seen in RS - YB plots, 98 were seen in BC - M plots, and 91 were seen in $\mathrm{WO}-\mathrm{BO}-\mathrm{NRO}$ plots $\left(\chi^{2}=1.00, \mathrm{df}=2, p=0.607\right)$. Considering all cavity-using species among all plots, red squirrels were most frequently tallied (0.43/ha/year), followed by eastern chipmunks (0.36/ha/year) (Fig. 1). Of bird species, 
black-capped chickadees were most frequently counted (0.33/ha/year) among all plots (Fig. 1).

Fourteen wildlife species that show at least facultative use of tree cavities as nesting or denning sites were observed during point counts (Appendices VIII, IX). Ten cavity-using species were found within RS - YB plots, all 14 species were found within $\mathrm{BC}-\mathrm{M}$ plots, and all but the winter wren were found within $\mathrm{WO}-\mathrm{BO}-\mathrm{NRO}$ plots. However, only 1 red squirrel and 1 red-breasted nuthatch were seen in $\mathrm{WO}-\mathrm{BO}-\mathrm{NRO}$ plots. Of the 14 species observed, 5 species were primary cavity-using species, and 2 species were weak excavators.

\section{Analyses of All Species Combined}

Between-year analyses of species diversity was similar among $\mathrm{RS}-\mathrm{YB}, \mathrm{BC}-\mathrm{M}$, and $\mathrm{WO}-\mathrm{BO}-\mathrm{NRO}$ forest types $(F=1.95, \mathrm{df}=2,27, p=0.162)$ (Table 2). Likewise, overall species richness was similar among the 3 forest cover types when considering both years data $(F=1.70, \mathrm{df}=2,27, p=0.202)$. Furthermore, total species densities among the 3 forest cover types were not significantly different $(F=2.53$, df $=2,27, p=$ 0.099).

Considering all data from 2001, percent shrub cover $\left(r^{2}=0.025\right)$ and basal area of standing wood $\left(\mathrm{r}^{2}=0.045\right)$ together explained $7.00 \%$ of variations in species diversity within each forest cover type. The all species diversity ANCOVA for 2001 data suggested species diversities were not significantly different among the 3 forest cover types $(F=2.94, \mathrm{df}=2,85, p=0.059)($ Table 2$)$. 
The percent shrub layer $\left(r^{2}=0.029\right)$, basal area $\left(r^{2}=0.041\right)$, and number of inventory trees $\left(r^{2}=0.029\right)$ together explained $9.91 \%$ of the variation in species richness within each forest cover type. There was sufficient evidence that species richness was higher among RS - YB plots than $\mathrm{WO}-\mathrm{BO}-\mathrm{NRO}$ plots, while $\mathrm{BC}-\mathrm{M}$ plot richness did not significantly differ from the other forest cover types in species richness (Table 2).

The percent shrub layer $\left(r^{2}=0.043\right)$, basal area $\left(r^{2}=0.032\right)$, and number of inventory trees $\left(r^{2}=0.041\right)$ together explained $11.66 \%$ of the variation in wildlife densities within each forest cover type. The mean plot density in RS - YB stands of all species combined was significantly higher than on $\mathrm{BC}-\mathrm{M}$ and $\mathrm{WO}-\mathrm{BO}-\mathrm{NRO}$ stands (Table 2).

\section{Analyses of Cavity-nesting Wildlife Species}

The between-year mean diversity of all cavity-using species did not differ significantly among $\mathrm{WO}-\mathrm{BO}-\mathrm{NRO}, \mathrm{BC}-\mathrm{M}$, and RS $-\mathrm{YB}$ plots $(F=0.76, \mathrm{df}=2,27, p=0.476)$ (Table 2). Similarly, mean species richness of all cavity-using species did not significantly differ among the 3 forest cover types $(F=0.59$, df $=2,27, p=0.536$ ) (Table 2). Likewise, mean plot densities of all cavity-using animals did not differ among the 3 forest cover types $(F=1.05, \mathrm{df}=2,27, p=0.363)$ (Table 2$)$.

For secondary cavity-using species only, species diversity was not significantly different among the 3 forest cover types $(F=0.33 \mathrm{df}=2,27, p=0.725)$ (Table 2). Similarly, secondary cavity-using species richness did not differ among the 3 forest cover types $(F=0.14 \mathrm{df}=2,27, p=0.873)$ (Table 2$)$. Also, secondary cavity-using animal 
densities were not significantly different among the 3 forest cover types $(F=0.46 \mathrm{df}=$ 2,27, $p=0.636)($ Table 2).

Considering data from 2001 only, basal area of standing wood varied significantly with all cavity-using species diversity $\left(r^{2}=0.048\right)$, richness $\left(r^{2}=0.049\right)$, and wildlife densities $\left(r^{2}=0.048\right)$ among all plots. The all cavity-using species diversity ANCOVA for 2001 data suggested species diversities were similar among the 3 forest cover types ( $F$ $=0.01, \mathrm{df}=2,86, p=0.987$ ) (Table 3). All cavity-using species richness also was similar among the 3 forest cover types $(F=0.02, \mathrm{df}=2,86, p=0.976)$ (Table 3$)$. Likewise, cavity-using animal densities were similar among the 3 forest cover types $(F=0.16$, df $=$ $2,86, p=0.854)$

Considering the secondary cavity-using species guild, basal area of standing wood $\left(r^{2}=0.067\right)$ and percent overstory cover $\left(r^{2}=0.023\right)$ varied significantly with secondary cavity-using species diversity among all plots $\left(r^{2}=0.090\right)$. The secondary cavity-using species diversities were similar among the 3 forest cover types $(F=0.74, \mathrm{df}=2,85, p=$ $0.479)$ (Table 3). Similarly, basal area $\left(r^{2}=0.049\right)$ and percent overstory cover $\left(r^{2}=\right.$ 0.024) varied significantly with secondary cavity-using species richness among all plots $\left(r^{2}=0.113\right)$. All cavity-using species richness did not differ significantly among the 3 forest cover types $(F=1.11, \mathrm{df}=2,85, p=0.334$ ) (Table 3$)$. Basal area was the lone significant covariate with secondary cavity-using animal densities among 2001 plots $\left(r^{2}=\right.$ 0.069). Secondary cavity-using animal densities were similar among the 3 forest cover types $(F=0.83, \mathrm{df}=2,86, p=0.441)$. 


\section{Relationships of Cavity-using Wildlife to Cavity Tree Abundances}

Mean cavity tree abundances differed among $\mathrm{RS}-\mathrm{YB}, \mathrm{BC}-\mathrm{M}$, and $\mathrm{WO}-\mathrm{BO}-\mathrm{NRO}$ forest cover types $(F=5.02, \mathrm{df}=2,67, p=0.009)$. Yet, there is insufficient evidence to suggest that a significant relationship exists between the number of cavity trees per plot and all cavity-using species densities per plot $\left(F=0.95\right.$, df $=1,73, p=0.332$, partial $R^{2}=$ 0.013). Similarly, no significant relationship was found between the number of cavity trees per plot and secondary cavity-user densities $(F=0.29$, df $=1,73, p=0.590$, partial $\left.R^{2}=0.004\right)$. However, after removing weak excavating species from the secondary cavity-using guild, a significant relationship was found between cavity trees per plot and true secondary cavity-using animal densities $\left(F=8.94, \mathrm{df}=1,73, p=0.004\right.$, partial $R^{2}=$ 0.109). Logistic regression analyses showed no significant relationships between the likelihood of each individual cavity-using species presence and the abundance of cavity trees.

\section{DISCUSSION}

Forests of the southern Allegheny Mountains are a mosaic of hardwood, northern hardwood, boreal forest cover types (Buckelew and Hall 1994; Hicks 1998). Because of the differences in silvicultural composition, I hypothesized that wildlife species diversity, richness, and densities would differ among these forest classes as well. Additionally, I hypothesized that cavity-using wildlife in particular would differ in diversity, richness and density among the 3 forest classes because cavity tree densities are not equal among 
these forest classes. Cavity nesting birds, for example, may be useful as forest health indicators because of their rigid link to standing trees, particularly secondary-using species dependent on available holes for nesting (Carey 1983). Using RS - YB, BC - M, and $\mathrm{WO}-\mathrm{BO}-\mathrm{NRO}$ forest cover types to represent the 3 forest classes, I found no evidence to support the hypotheses that all species diversity, richness, and density, as well as all cavity-using species diversity, richness, and density, differ among the forest cover types. Thus, it appears that the ability to support avian and cavity-using communities is relatively equal among mature forest stands (i.e., $>90$ yrs) of the 3 main forest classes within southern Allegheny Mountain forests, yet the likelihood of occurrence of individual species varies with individual stand characteristics.

Of habitat structure, the basal area of standing wood was the only consistent covariate in wildlife guild diversity, richness, and density models. In central Allegheny Mountain hardwood forests bird species richness and abundance sharply increased in stands with basal areas below $18 \mathrm{~m}^{2} /$ ha (but not for interior forest species), and decreased sharply in stands with basal areas exceeding $26 \mathrm{~m}^{2} /$ ha (due to diminishing edge species) (Ross et al. 2001). The mean basal area of my study plots was $26-27 \mathrm{~m}^{2} /$ ha and mean stand age was about 103 yr (Chapter 2). Higher basal areas are generally associated with lower shrub and understory density. In turn, greater vertical diversity (i.e., higher shrub and understory densities) may accommodate greater avian diversity and abundances (Rodewald and Smith 1998; Hobson and Bayne 2000). Thus, management strategies involving timber harvesting at $90-100$ yr rotations should mimic small gap disturbances within forest patches to optimize bird diversity and richness among forest edge and interior species. 


\section{Wildlife Species Among Forest Cover Types}

Point count surveys did not detect differences in wildlife species diversity or richness among $\mathrm{RS}-\mathrm{YB}, \mathrm{BC}-\mathrm{M}$, and $\mathrm{WO}-\mathrm{BO}-\mathrm{NRO}$ forest cover types, yet avian community structures within southern Allegheny Mountain forests vary along an elevational gradient. Some species were only recorded in RS - YB stands, such as Swainson's thrush and the red crossbill (Loxia curvirostra). Other species, such as the winter wren and hermit thrush, were only counted within the northern forest types. Three species were found only in BC - M stands, yet only the alder flycatcher was recorded more than once. Lower down, the white-breasted nuthatch (Sitta carolinensis), tufted titmouse (Baeolophus bicolor), and wood thrush appeared only in hardwood stands, while the eastern woodpewee (Contopus virens) and black-and-white warbler (Mniotilta varia) were observed only in $\mathrm{WO}-\mathrm{BO}-\mathrm{NRO}$ plots.

Differences in forest structure, such as basal area, understory and shrub cover, among stands of the same forest type may shape differences in breeding bird community structure. Chances of black-throated green warbler presence seemed to increase with increased stand basal area and decreased stem densities and the Blackburnian warbler also was associated with larger diameter trees. Likewise, Hobson and Bayne (2000) found these species more abundant on contiguous forest tracts than on fragmented areas. Openings in understory and shrub cover negatively impact black-throated blue warbler forest movements (Belisle et al. 2001, Harris and Reed 2001), thus I found black-throated blue warbler presence associated with denser shrub layers. Moreover, I found the Canada warbler (Wilsonia canadensis) only in RS - YB and BC - M plots with shrub cover 
$>75 \%$, with rhododendron (Rhododendron maximum) the major shrub component.

Hobson and Schiek (1999) found significantly more Canada warblers in 28 year-old postharvest stands than on uncut stands, possibly due to the denser shrub layer on postharvest stands.

I found blue-headed vireo (Vireo solitarius) presence associated with understory cover, in concurrence with results from a Canadian boreal forest (Drolet et al. 1999). In contrast, Drolet et al. (1999) found the American robin (Turdus migratorius) in association with poorly forested landscapes. Similarly, I found the American robin in association with increased stems counts of black cherry, an early successional species (Marquis 1990), and red maple, which is common on poor growing sites (Walters and Yawney 1990).

Furthermore, the wood thrush (Hylocichla mustelina), Swainson's thrush, hermit thrush, and veery (Catharus fuscescens) are all considered ground-foraging species, yet foraging heights of the thrush species were stratified among species present from $0-8 \mathrm{~m}$ above ground level (Holmes and Robinson 1988). Wood thrushes spend $>98 \%$ of foraging time in $<2 \mathrm{~m}$ from the ground (Holmes and Robinson 1988). Similarly, I found the likelihood of wood thrush presence increased significantly with increased overstory cover, which suggests less understory and shrub cover presence. Furthermore, Swainson's thrushes will use a slightly higher foraging substrate (Holmes and Robinson 1988). Likewise, I found the likelihood of Swainson's thrush presence increased significantly with increased shrub cover. Thus, the presence or absence of a particular bird species may not wholly depend on forest cover type; the amount and quality of subcanopy vegetation also may influence avian community structure. 
The occurrences of 9 of 13 species were directly related to amounts of sugar maple and yellow birch present in stands. These tree species occur together in greatest proportion in an elevational gradient between the pure red spruce stands and northern hardwood forest types such as BC - M, maple - beech (Fagus grandifolia) - birch, and beech - sugar maple (Eyre 1980). Thus, edge effects (i.e., increased species occurrences) may happen between forest cover types of similar ages.

As with foraging substrate resources, I found evidence that cavity tree resources may influence dependent, secondary cavity-nesting bird densities. Conifers usually will not hold durable and usable cavities for secondary species (Van Balen et al. 1982). Indeed, I observed the tufted titmouse and white-breasted nuthatch only among hardwood stands. More so, cavity tree abundances were highest within the $\mathrm{WO}-\mathrm{BO}-\mathrm{NRO}$ forest cover type, along with and $75 \%$ and $66 \%$ of all tufted titmouse and white-breasted nuthatch observations, respectively. In contrast, I observed weak-excavating species (i.e., red-breasted nuthatch, black-capped chickadee) mostly in the RS - YB forest cover type ( $85 \%$ and $63 \%$ of all observations, respectively), and tree hardness influences nest-site choices of excavating birds (Schepps et al. 1999). Thus, the softer, decayed wood of red spruce and yellow birch may provide easier excavating substrate than other hardwood species for weak excavators. Furthermore, territoriality has been shown to influence differential habitat use among sympatric chickadees (Hill and Lein 1989). The larger tufted titmouse and white-breasted nuthatch may out-compete the smaller red-breasted nuthatch and black-capped chickadee for territories, thus the weak-excavators are relegated to exploiting that part of their niche where there is no sympatric overlap. 
Nest parasitism by the brown-headed cowbird (Molothrus ater) (hereafter referred to as cowbird) has been identified as a limiting factor to nest success of several interior forest bird populations (Burke and Nol 2000; Flaspohler and Temple 2001). The cowbird is associated with open fields and pastures, yet may penetrate $>300 \mathrm{~m}$ into forested landscape to find other active nests in which to lay eggs (Flaspohler and Temple 2001). I noted cowbirds only in hardwood plots (i.e., $\mathrm{BC}-\mathrm{M}$ and $\mathrm{WO}-\mathrm{BO}-\mathrm{NRO}$ cover types). The WO - BO - NRO plots especially are closer to valley farmlands, thus chances of cowbird nest parasitism would be greatest among these forests due to elevational aspects. Even gypsy moth defoliation of large oaks (>38.1 cm diameter) may provide adequate openings for cowbird penetration within otherwise contiguous tracts of forested cover (Bell and Whitmore 2000). In West Virginia, Bell and Whitmore (2000) found greatest nest success of Acadian flycatchers (Empidonax virescens) in forests with low snag abundance and hence, increased canopy cover. Similarly, I found Acadian flycatcher presence associated with overstory cover. Thus, some forested land may be nonproductive as breeding habitat. Such ideas have led others to conclude that permanent forest loss (e.g., from development, road construction) may be more detrimental to forest health than managed logging practices (Fredericksen 1998).

In contrast, red squirrels and eastern chipmunks (i.e., sciurids), which may compete for tree holes with secondary cavity-nesting birds, may be major nest predators to open nesting bird species (King et al. 1998). Both sciurids may be associated with interior forest conifer cover (King et al. 1998). Indeed, I found most red squirrels in plots with $>10 \%$ cover of red spruce; others were noted in association with eastern hemlock. 
Similarly, I found many eastern chipmunks in association with eastern hemlock among hardwood cover.

\section{Management Implications}

Analyzing spruce forests across northern North America, Nekola and White (1999) found that similarities in vegetative diversity decreased with increased distance between forest patches. Thus, wildlife species associated with vegetative cover also will decline with increased separation from similar cover. Furthermore, variations in population trends of many Neotropical migrant birds appear correlated with elevation (James et al. 1996). To maintain biodiversity among southern Allegheny Mountain boreal forests, continuity among cover at varying elevations is a main priority. Although past abuses of southern Allegheny Mountain forests have prompted increased scrutiny of timber harvesting practices, relatively little attention is given to expanding development and obligatory road construction (Fredericksen 1998). Nonetheless, these advances produce more permanent scars among otherwise contiguous forest tracts.

In the southern Allegheny Mountains, if development were minimized among the higher northern hardwood and boreal forests, negatively impacting edge effects also would be minimized on boreal forests. Still, because red spruce stands are shrinking in area, greater amounts of yellow birch and sugar maple will grow in place of the spruce. Because the chances of occurrence of many bird species increase with increasing sugar maple and yellow birch, managers should expect to see positive trends in populations of 
many species. However, some species populations, such as the red-breasted nuthatch and winter wren will likely experience negative impacts.

Other edge effects (i.e., cowbird parasitism) presently are more apparent among the lower, central hardwood forest stands. In the MNF of West Virginia, Duguay et al. (2001) found nest parasitism rates by cowbirds on 4 of 5 host species relatively equal among clearcut, two-aged, and control stands 15 years after harvesting. Therefore, the most important factors to consider when harvesting may be landscape level arrangements of silvicultural treatments, as well as treatment acreage, rather than the actual treatments themselves.

Point count results indicate that breeding bird communities may differ among forest cover types. Presence of some bird species, for example the red-breasted nuthatch, appears related to the compositional structure of forest cover. Presence of other species, for example Swainson's thrush, appears directly related to vertical structure. In turn, vertical structure also may depend on the compositional structure of overstory tree species. Moreover, abiotic edge effects, such as increased wind strength, have been shown to influence the amount of vertical foraging substrate used by tufted titmice and Carolina chickadees (P. carolinensis), as well as on a horizontal plane (Dolby and Grubb 1999).

My results concur with Hobson and Bayne (2000), for example, who found increased conifer in Canadian mixed wood stands influenced use by bird species such as the magnolia warbler (Dendroica magnolia). Similarly, increased density of shrub cover in mature stands resulted in greater abundances of Canada warblers (Hobson and Bayne 
2000). Thus, when considering wildlife needs, forest managers should not only regard stand composition and size, but vegetative structure as well.

Generally, on a landscape level avian species reproductive output is highest with minimal cover fragmentation and lowest with maximum cover fragmentation (With and King 2001). However, density of a wildlife species is not necessarily a good indicator of habitat quality, if habitat quality is to be measured by reproductive success (Vickery et al. 1992; Roberts and Norment 1999). For example, although breeding male abundances may not differ among forest stands, pairing success of breeding males may correlate with variations in habitat characteristics such as forest stand composition and structure (Roberts and Norment 1999). Furthermore, nest success may vary between breeding pairs in apparently (i.e., compositionally and structurally) similar forest stands due to conditions such as differential cowbird parasitism (Donovan et al. 1995).

\section{Future Considerations}

Reproductive output may be a better indicator of habitat suitability than species density (Hagan et al. 1996). Thus, nest searches and monitoring should be done to provide better habitat suitability information. Fledgling success rates should be compared among forest stands for better suitability information.

When making decisions concerning biodiversity issues mangers should not think of forest stands only as a 2-dimensional layout. Vertical structure can be just as important as stand size, composition, and juxtaposition across a horizontal landscape. Perhaps the best tool for making such determinations is GIS software. Field information 
should include information about the vertical structure of forest cover. Analysis with GIS allows the overlaying of various layers of data coverage, so stand information can include not only information about overstory composition, but also information about understory and shrub layer vegetation. For avian diversity, understory and shrub composition may be just as important as overstory cover. Notwithstanding, GIS analysis allows spatial considerations across the horizontal plane as well. Therefore, the effects on biodiversity of the juxtaposition of various silvicultural treatments across a landscape also may be assessed. For example, point count information should be collected from RS - YB, BC $\mathrm{M}$, or $\mathrm{WO}-\mathrm{BO}-\mathrm{NRO}$ stands of various ages. Over time, the 3-dimensional changes in point vegetation characteristics can be monitored and tested along with information regarding wildlife species richness and densities. Such analyses would likely provide more useful and complete information than constantly testing and making inferences from only certain aspects of the complete picture. Also, it is probably less laborintensive. 


\section{LITERATURE CITED}

Acciavatti, R. E., T. J. Allen, A. R. Miller, L. L. Pechuman, B. C. Kondratieff, R. F. Kirchner, A. G. Wheeler, Jr., S. M. Clark, E. van den Berghe, and W. J. Arnold. 1993. Pages 143-178 in Stephenson, S. L., editor. Upland forests of West Virginia. McClain Printing Company, Parsons, West Virginia.

Avery, T. E., and H. E. Burkhart. 1997. Forest Measurements. Fourth Edition. McGraw Hill Company, Boston, Massachusetts, USA.

Bell, J. L., and R. C. Whitmore. 2000. Bird nesting ecology in a forest defoliated by gypsy moths. Wilson Bulletin 112:524-531.

Belisle, M, A. Desrochers, and M. J. Fortin. 2001. Influence of forest cover on the movements of forest birds: A homing experiment. Ecology 82:1893-1904.

Brantley, E. A., R. L. Anderson, and G. Smith. 1994. How to identify ozone injury on eastern forest bioindicator plants. U.S. Forest Service, Protection Report R8PR25.

Buckelew, A. R., Jr., and G. A. Hall. 1994. The West Virginia breeding bird atlas. University of Pittsburgh Press, Pittsburgh, Pennsylvania, USA.

Burke, D. M., and E. Nol. 2000. Landscape and fragment size effects on reproductive success of forest-breeding birds in Ontario. Ecological Applications 10:17491761.

Carey, A. B. 1983. Monitoring diurnal, cavity-using bird populations. Pages 188-199 in Davis, J. W., G. A. Goodwin, and R. A. Ockenfels, technical coordinators. Snag habitat management: Proceedings of the symposium. U.S. Forest Service, General Technical Report RM-99. 
Carvell, K. L. 1986. Effect of past history on present stand composition and condition. Pages 1-7 in Smith, H. C., and M. C. Eye, editors. Guidelines for managing immature Appalachian hardwood stands. West Virginia University Books, Morgantown, West Virginia.

Clarkson, R. B. 1993. Destruction of the upland forests by lumbering and fire. Pages 35-65 in Stephenson, S. L., editor. Upland forests of West Virginia. McClain Printing Company, Parsons, West Virginia.

Cody, R. P., and J. K. Smith. 1997. Applied statistics and the SAS programming language. Simon and Schuster Incorporated, New York, New York. 445 pp.

Conner, R. N., and H. S. Crawford. 1974. Woodpecker foraging in Appalachian clearcuts. Journal of Forestry 72:564-566.

Davidar, P., K. Yoganand, and T. Ganesh. 2001. Distribution of forest birds in the Andaman islands: importance of key habitats. Journal of Biogeography 28:663671.

DeGraaf, R. M., and A. L. Shigo. 1985. Managing cavity trees for wildlife in the Northeast. U.S. Forest Service General Technical Report NE-101. 23pp.

Dolby, A. S., and T. C. Grubb, Jr. 1999. Effects of winter weather on horizontal and vertical use of isolated fragments by bark-foraging birds. Condor 101:408-412.

Donovan, T. M., F. R. I. Thompsoni, J. Faaborg, and J. R. Probst. 1996. Reproductive success of migratory birds in habitat sources and sinks. Conservation Biology 9:1380-1395.

Dowdy, S. M., and S. Wearden. 1991. Statistics for research. John Wiley and Sons, Incorporated. New York, New York, USA. 
Drolet, B., A. Desrochers, and M. J. Fortin. 1999. Effects of landscape structure on nesting songbird distribution in a harvested boreal forest. Condor 101:699-704.

Duguay, J. P., P. B. Wood, and J. V. Nichols. 2001. Songbird abundance and avian nest survival rates in forests fragmented by different silvicultural treatments. Conservation Biology 15:1405-1415.

Estepp, R. 1992. Soil survey of Pendleton County, West Virginia. National Cooperative Soil Survey.

Eyre, F. H. 1980. Forest cover types of the United States and Canada. Society of American Foresters, Washington, DC, USA.

Fenneman, N. M. 1938. Physiography of eastern United States. McGraw-Hill Book Co., New York City, New York, USA.

Flaspohler, D. J., and S. A. Temple. 2001. Species-specific edge effects on nest effects and breeding birds density in a forested landscape. Ecological Applications $11: 32-46$.

Flegel, D. G. 1999. Soil survey of Pocahontas County, West Virginia. National Cooperative Soil Survey.

Fredericksen, T. S. 1998. Impacts of logging and development on Central Appalachian forests. Natural Areas Journal 18:175-178.

Green, N. B., and T. K. Pauley. 1987. Amphibians and reptiles of West Virginia. University of Pittsburgh Press, Pittsburgh, Pennsylvania, USA.

Hagan, J. M. III, W. M. Vander Haegen, and P. S. McKinley. 1996. The early development of forest fragmentation in birds. Conservation Biology 10(1):188202. 
Hall, G. A. 1983. West Virginia Birds. Carnegie Museum of Natural History Special Publication No. 7, Pittsburgh, Pennsylvania, USA.

Harris, R. J., and M. J. Reed. 2001. Territorial movements of black-throated blue warblers in a landscape fragmented by forestry. Auk 118:544-549.

Harrison, H. H. 1975. Birds' nests. Houghton Mifflin Company, New York, New York. 257 pages.

Hicks, R. R., Jr. 1998. Ecology and Management of central hardwood forests. John Wiley \& Sons, New York City, New York, USA.

Hill, B. G., and M. R. Lein. 1989. Territory overlap and habitat use of sympatric chickadees. Auk 106:259-268.

Hobson, K. A., and E. Bayne. 2000. The effects of stand age on avian communities in aspen-dominated forests of central Saskatchewan, Canada. Forest Ecology and Management 136:121-134. , and J. Schiek. 1999. Changes in bird communities in a boreal mixedwood forest: Harvest and wildfire effects over 30 years. Ecological Applications 9:849-863.

Holmes, R. T., and S. K. Robinson. 1988. Spatial patterns, foraging tactics, and diets of ground-foraging birds in a northern hardwood forest. Wilson Bulletin 100:377394.

James, F. C., and H. H. Shugart, Jr. 1970. A quantitative method of habitat description. Audubon Field Notes 24:727-736.

James, F. C., C. E. McCulloch, and D. A. Wiedenfeld. 1996. New approaches to the analysis of population trends in land birds. Ecology 77:13-27. 
King, D. I., C. R. Griffin, and R. M. DeGraaf. 1998. Nest predator distribution among clearcut forest, forest edge and forest interior in an extensively forested landscape. Forest Ecology and Management 104:151-156.

Lesser, W. H. 1993. Prehistoric human settlement in the upland forest region. Pages 231-260 in Stephenson, S. L., editor. Upland forests of West Virginia. McClain Printing Company, Parsons, West Virginia.

MacArthur, R. H., and E. O. Wilson. 1967. The theory of island biogeography. Princeton University Press, Princeton, New Jersey, USA.

Manolis, J. C., D. E. Andersen, and F. J. Cuthbert. 2000. Patterns in clearcut edge and fragmentation effect studies in northern hardwood-conifer landscapes: retrospective power analysis and Minnesota results. Wildlife Society Bulletin 28(4):1088-1101.

Marcot, B. G. 1983. Snag use by birds in Douglas-fir clearcuts. Pages 134-139 in Davis, J. W., G. A. Goodwin, and R. A. Ockenfels, technical coordinators. Snag habitat management: Proceedings of the symposium. U.S. Forest Service, General Technical Report RM-99.

Marquis, D. A. 1990. Prunus serotina Ehrh. black cherry. pp. 594-604 in Silvics of North America. Vol. 2. Hardwoods. Burns, R. M., Honkala, B. H., technical coordinators. USDA Agricultural Handbook 654, Washington, D.C.

Martin, K., and J. M. Eadie. 1999. Nest webs: A community-wide approach to the management and conservation of cavity-nesting forest birds. Forest Ecology and Management 115:243-257. 
Marzluff, J. M., and L. J. Lyon. 1983. Snags as indicators of habitat suitability for open nesting birds. Pages 140-146 in Davis, J. W., G. A. Goodwin, and R. A. Ockenfels, technical coordinators. Snag habitat management: Proceedings of the symposium. U.S. Forest Service, General Technical Report RM-99.

Newton, I. 1994. The role of nest sites in limiting the numbers of hole-nesting birds: A review. Biological Conservation 70:265-276.

Nekola, J. C., and P. S. White. 1999. The distance decay of similarity in biogeography and ecology. Journal of Biogeography 26:867-878.

Nur, N., S. L. Jones, and G. R. Geupel. 1999. Statistical guide to data analysis of avian monitoring programs. U.S. Fish and Wildlife Service, Biological Technical Publication BTR-R6001-1999.

Odom, R. H., W. M. Ford, J. W. Edwards, C. W. Stihler, and J. M. Menzel. 2001. Developing a habitat model for the endangered Virginia northern flying squirrel (Glaucomys sabrinus fuscus) in the Allegheny Mountains of West Virginia. Biological Conservation 99:245-252.

Pyle, R. E., W. W. Beverage, T. Yoakum, D. P. Amick, W. F. Hatfield, and D. E. McKinney. 1982. Soil survey of Randolph County area main part, West Virginia. National Cooperative Soil Survey.

Ralph, C. J., J. R. Sauer, and S. Droege, editors. 1995. Monitoring bird populations by point counts. U. S. Forest service, General Technical Report PSW-GTR-149.

Roberts, C., and C. J. Norment. 1999. Effects of plot size and habitat characteristics on breeding success of scarlet tanagers. Auk 116:73-82. 
Rodewald, A. D., and R. H. Yahner. 2000. Bird communities associated with harvested hardwood stands containing residual trees. Journal of Wildlife Management 64:924-932.

Rodewald, P. G., and K. G. Smith. 1998. Short-term effects of understory and overstory management on breeding birds in Arkansas. Journal of Wildlife Management 62:1411-1417.

Ross, B. D., M. L. Morrison, W. Hoffman, T. S. Fredericksen, R. J. Sawicki, E. Ross, M. B. Lester, J. Beyea, and B. N. Johnson. 2001. Bird relationships to habitat characteristics created by timber harvesting in Pennsylvania. Journal of the Pennsylvania Academy of Science. 74:71-84.

Sanderson, H. R. 1975. Den-tree management for tree squirrels. Wildlife Society Bulletin. 3:125-131.

Schepps, J., S. Lohr, and T. E. Martin. 1999. Does tree hardness influence nest-tree selection by primary cavity nesters? Auk 116:658-665.

Stephenson, S. L. 1993. Upland forest vegetation. Pages 11-34 in Stephenson, S. L., editor. Upland forests of West Virginia. McClain Printing Company, Parsons, West Virginia.

Stephenson, S. L., and H. S. Adams. 1993. Threats to the Upland Forests. Pages 261273 in Stephenson, S. L., editor. Upland forests of West Virginia. McClain Printing Company, Parsons, West Virginia.

Stribling, H. L. 1990. Bird community response to timber stand improvement and snag retention. Northern Journal of Applied Forestry 7:35-38. 
Van Balen, J. H., C. J. H. Booy, J. A. Franeker, and E. R. Osieck. 1982. Studies on holenesting birds in natural nest sites 1 . Availability and occupation of natural nest sites. Ardea 70:1-24.

Vickery, P. D., M. L. Hunter, Jr., and J. V. Wells. 1992. Is density an indicator of breeding success? Auk 109:706-710.

Villard, M. A., M. K. Trzcinski, G. Merriam. 1999. Fragmentation effects on forest birds: relative influence of woodland cover and configuration on landscape occupancy. Conservation Biology 13:774-783.

Walters, R. S., and H. W. Yawney. Acer rubrum L. red maple. pp. 60 - 69 in Silvics of North America. Vol. 2. Hardwoods. Burns, R. M., Honkala, B. H., technical coordinators. USDA Agricultural Handbook 654, Washington, D.C.

With, K. A., and A. W. King. 2001. Analysis of landscape sources and sinks: The effect of spatial pattern on avian demography. Biological Conservation 100:75-88.

Zar, J. H. 1999. Biostatistical Analysis. Fourth Edition. Prentice Hall, Upper Saddle River, New Jersey, USA. 
Table 1. Most common birds recorded in 50-meter point count plots in Mbnongahela National Forest, West Virginia, 2000-2001. Numbers reflect maximumtally within each plot ( $n=30$ for each forest type).

\begin{tabular}{|c|c|c|c|c|c|c|}
\hline \multirow[b]{2}{*}{ Common Name } & \multirow[b]{2}{*}{ Scientific Name } & \multicolumn{3}{|c|}{ Forest Type $^{\mathrm{a}}$} & \multirow[b]{2}{*}{$\chi^{2}$} & \multirow[b]{2}{*}{$p$-valuec } \\
\hline & & $\mathrm{S}$ & $\mathrm{N}$ & $\mathrm{C}$ & & \\
\hline Acadian flycatcher & Enpidonax virescens & $1 a^{d}$ & $2 a^{d}$ & $13 b^{d}$ & 16.625 & $\varangle 0.001$ \\
\hline American robin & Turdus migratorius & $10 \mathrm{a}$ & $8 a$ & $6 a$ & 1.000 & 0.607 \\
\hline Blackburnian warbler & Dendroicafusca & $38 \mathrm{a}$ & $17 \mathrm{~b}$ & $15 b$ & 13.914 & 0.001 \\
\hline black-capped chickadee & Poecile atricapilla & $36 a$ & $14 b$ & $9 b$ & 20.983 & $<0.001$ \\
\hline black-throated blue warbler & Dendroica caerulescens & $33 \mathrm{a}$ & $8 b$ & $8 b$ & 25.510 & $<0.001$ \\
\hline black-throated green warbler & Dendroica virens & $25 \mathrm{a}$ & $30 \mathrm{a}$ & $20 \mathrm{a}$ & 2000 & 0.368 \\
\hline blue jay & Cyanocitta cristata & $8 \mathrm{a}$ & $9 \mathrm{a}$ & $8 a$ & 0.080 & 0.961 \\
\hline blue-headed vireo & Vireo solitarius & $12 \mathrm{a}$ & $17 \mathrm{a}$ & $13 \mathrm{a}$ & 1.000 & 0.607 \\
\hline brown creeper & Centhia americana & $15 \mathrm{a}$ & $7 \mathrm{a}$ & $\mathrm{ab}$ & 15.364 & $<0.001$ \\
\hline cedar waxwing & Bombycillacedronm & $7 \mathrm{a}$ & $10 \mathrm{a}$ & $1 \mathrm{~b}$ & 7.000 & 0.030 \\
\hline dark-eyedjunco & Juncohyemalis & $48 \mathrm{a}$ & $24 b$ & $4 c$ & 38.316 & $\varangle 0.001$ \\
\hline downy woodpecker ${ }^{b}$ & Picoides pubescens & $2 \mathrm{a}$ & $9 b$ & $12 b$ & 6.870 & 0.032 \\
\hline Eastern chipmunk ${ }^{\mathrm{b}}$ & Tamias striatus & $2 \mathrm{a}$ & $35 b$ & $47 \mathrm{~b}$ & 38.786 & $<0.001$ \\
\hline golden-crowned kinglet & Regulus satrapa & $33 \mathrm{a}$ & $6 b$ & $0 \mathrm{c}$ & 47.538 & $<0.001$ \\
\hline Eastem wood-pewee & Contopus virens & $\mathrm{Oa}$ & $\mathrm{Oa}$ & $15 b$ & 30.000 & $<0.001$ \\
\hline hermit thrush & Catharus guttatus & $12 \mathrm{a}$ & $17 \mathrm{a}$ & $0 b$ & 15.793 & $<0.001$ \\
\hline magnolia warbler & Dendroicam & $39 a$ & $20 \mathrm{~b}$ & $3 c$ & 31.387 & $<0.001$ \\
\hline ovenbird & Seirus aurocapillus & $0 \mathrm{a}$ & $11 \mathrm{~b}$ & $12 \mathrm{~b}$ & 11.565 & 0.003 \\
\hline red squirrel $^{b}$ & Tamiasciunis hudsonicus & $40 \mathrm{a}$ & $31 \mathrm{a}$ & $0 b$ & 34.750 & $<0.001$ \\
\hline red-breasted nuthatch ${ }^{\mathrm{b}}$ & Sittacanadensis & $25 \mathrm{a}$ & $3 b$ & $1 \mathrm{~b}$ & 36.690 & $<0.001$ \\
\hline red-eyed vireo & Vireo olivaceus & $10 \mathrm{a}$ & $37 \mathrm{~b}$ & $36 \mathrm{~b}$ & 16.940 & $<0.001$ \\
\hline scarlet tanager & Piranga olivacea & $6 a$ & 11a & $14 a$ & 3.161 & 0.206 \\
\hline Swainson's thrush & Catharus ustulatus & $20 \mathrm{a}$ & $0 b$ & $a b$ & 40.000 & $\varangle 0.001$ \\
\hline tufted titmouse $^{\mathrm{b}}$ & Baeolophus bicolor & $\mathrm{Oa}$ & $5 \mathrm{a}$ & $14 a$ & 15.895 & $<0.001$ \\
\hline veery & Cathamus fuscescens & $16 a$ & $22 \mathrm{a}$ & $18 \mathrm{a}$ & 1.000 & 0.607 \\
\hline white-breasted nuthatch ${ }^{\mathrm{b}}$ & Sitta carolinensis & $\mathrm{Oa}$ & $15 b$ & $27 \mathrm{~b}$ & 26.143 & $<0.001$ \\
\hline wood thrush & Hylocichla mustelina & $\mathrm{Oa}$ & $9 b$ & $12 \mathrm{~b}$ & 11.143 & 0.004 \\
\hline yellow-bellied sapsucker & Sphyrapicus varius & la & $2 \mathrm{a}$ & $14 b$ & 18.471 & $<0.001$ \\
\hline \multicolumn{7}{|c|}{ "Forest types are as follows: } \\
\hline \multicolumn{7}{|c|}{ S- subalpine (red spruce - yellow birch) forest cover type; } \\
\hline \multicolumn{7}{|c|}{$\mathrm{N}$ - nothem hardwood (black cherry- maple) forest cover type; and } \\
\hline \multicolumn{7}{|c|}{ C- central hardwood (white oak - black oak - Northern red oak) forest cover type. } \\
\hline \multicolumn{7}{|c|}{ bsecies demonstrates at least facultative use of tree cavities. } \\
\hline \multicolumn{7}{|c|}{$3 \times 2 \chi^{2} \operatorname{test}\left(\chi_{0.05,2}^{2}=5.991\right)$} \\
\hline \multicolumn{7}{|c|}{${ }^{\mathrm{d}}$ Same letters indicate no likelihood separation, $2 \times 2 \chi^{2}$ test $\left(\chi_{0.05,1}^{2}=3.841\right)$} \\
\hline
\end{tabular}


Table 2. Mean wildlife species diversity, richness, and density values among forest cover types for years 2000 and 2001 data combined, Monongahela National Forest, West Virginia".

\begin{tabular}{|c|c|c|c|c|c|c|c|}
\hline \multirow[b]{3}{*}{ Guild $^{c}$} & \multirow[b]{3}{*}{ Value } & \multicolumn{6}{|c|}{ Forest Cover Type $^{b}$} \\
\hline & & \multicolumn{2}{|c|}{ RS - YB } & \multicolumn{2}{|c|}{$\mathrm{BC}-\mathrm{M}$} & \multicolumn{2}{|c|}{$\mathrm{WO}-\mathrm{BO}-\mathrm{NRO}$} \\
\hline & & 区 & $\mathrm{SE}$ & $\bar{x}$ & SE & 口 & $\mathrm{SE}$ \\
\hline \multirow[t]{3}{*}{ All } & Diversity $^{\mathrm{d}}$ & 0.935 & 0.0239 & 0.8530 & 0.0400 & 0.8403 & 0.0397 \\
\hline & Richness ${ }^{\mathrm{e}}$ & 9.400 & 0.483 & 8.100 & 0.707 & 7.950 & 0.639 \\
\hline & Density ${ }^{f}$ & 15.469 & 0.930 & 12.669 & 1.153 & 12.796 & 0.975 \\
\hline \multirow[t]{3}{*}{ Cavity } & Diversity ${ }^{\mathrm{d}}$ & 0.2765 & 0.0459 & 0.3265 & 0.0566 & 0.3600 & 0.0451 \\
\hline & Richness $^{\mathrm{e}}$ & 2.050 & 0.276 & 2.300 & 0.391 & 2.550 & 0.285 \\
\hline & Density $^{\mathrm{f}}$ & 3.756 & 0.534 & 3.819 & 0.704 & 4.711 & 0.515 \\
\hline \multirow[t]{3}{*}{ Secondary } & Diversity $^{\mathrm{d}}$ & 0.2506 & 0.0448 & 0.2405 & 0.0552 & 0.2009 & 0.0363 \\
\hline & Richness $^{\mathrm{e}}$ & 1.900 & 0.250 & 1.850 & 0.350 & 1.650 & 0.182 \\
\hline & Density $^{f}$ & 3.565 & 0.485 & 3.183 & 0.663 & 3.438 & 0.424 \\
\hline
\end{tabular}

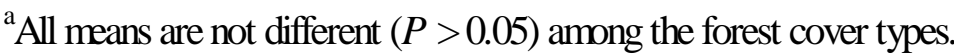

${ }^{\mathrm{b}}$ Society of American Foresters cover types: $\mathrm{RS}-\mathrm{YB}=$ red spruce - yellow birch, $\mathrm{BC}-\mathrm{M}=$ black cherry - maple, and WO - BO - NRO = white oak - black oak - Northern red oak (Eyre 1980).

${ }^{c}$ Wildlife species tallied in point counts: All = all species, Cavity = all cavity-using species, and Secondary = weak and secondary cavity-using species (Martin and Eadie 1999).

${ }^{d}$ Shannon's diversity index (Zar 1999).

eNumber of species/plot ( 1 plot $=0.785$ ha $)$.

${ }^{\mathrm{f}}$ Number of animals/ha. 
Table 3. Mean wildlife species diversity, richness, and density values among forest cover types for year 2001 data alone, Monongahela National Forest, West Virginia ${ }^{a}$.

\begin{tabular}{|c|c|c|c|c|c|c|c|}
\hline \multirow[b]{3}{*}{ Guild $^{c}$} & \multirow[b]{3}{*}{ Value } & \multicolumn{6}{|c|}{ Forest Cover Type $^{b}$} \\
\hline & & \multicolumn{2}{|c|}{ RS - YB } & \multicolumn{2}{|c|}{$\mathrm{BC}-\mathrm{M}$} & \multicolumn{2}{|c|}{ WO - BO - NRO } \\
\hline & & Х & SE & 区 & $\mathrm{SE}$ & 区 & $\mathrm{SE}$ \\
\hline \multirow[t]{3}{*}{ All } & Diversity ${ }^{\mathrm{d}}$ & $1.011 \mathrm{a}$ & 0.0189 & $0.967 \mathrm{a}$ & 0.0234 & $0.904 a$ & 0.0256 \\
\hline & Richness $^{\mathrm{e}}$ & $11.300 \mathrm{a}$ & 0.492 & $10.167 \mathrm{ab}$ & 0.484 & $8.900 \mathrm{~b}$ & 0.490 \\
\hline & Density $^{\mathrm{f}}$ & $18.929 a$ & 0.834 & $16.001 \mathrm{~b}$ & 0.783 & $14.175 b$ & 0.880 \\
\hline \multirow[t]{3}{*}{ Cavity } & Diversity $^{\mathrm{d}}$ & $0.373 a$ & 0.0328 & $0.393 \mathrm{a}$ & 0.0435 & $0.383 \mathrm{a}$ & 0.0412 \\
\hline & Richness ${ }^{\mathrm{e}}$ & $2.700 \mathrm{a}$ & 0.180 & $2.900 \mathrm{a}$ & 0.273 & $2.800 \mathrm{a}$ & 0.277 \\
\hline & Density $^{\mathrm{f}}$ & $4.924 a$ & 0.395 & $4.838 \mathrm{a}$ & 0.511 & $5.093 \mathrm{a}$ & 0.5386 \\
\hline \multirow[t]{3}{*}{ Secondary } & Diversity $^{\mathrm{d}}$ & $0.321 \mathrm{a}$ & 0.0299 & $0.322 \mathrm{a}$ & 0.0386 & $0.252 \mathrm{a}$ & 0.0357 \\
\hline & Richness ${ }^{\mathrm{e}}$ & $2.333 \mathrm{a}$ & 0.154 & $2.400 \mathrm{a}$ & 0.218 & $1.933 \mathrm{a}$ & 0.197 \\
\hline & Density $^{f}$ & $4.456 \mathrm{a}$ & 0.360 & $4.160 \mathrm{a}$ & 0.457 & $3.862 \mathrm{a}$ & 0.442 \\
\hline
\end{tabular}

${ }^{a}$ All means followed by the same letter are not different $(P>0.05)$ among the forest cover types.

${ }^{\mathrm{b}}$ Society of American Foresters cover types: RS - YB = red spruce - yellow birch, BC - M= black cherry - maple, and WO - BO - NRO = white oak - black oak - Northern red oak (Eyre 1980).

${ }^{c}$ Wildlife species tallied in point counts: All $=$ all species, Cavity $=$ all cavity-using species, and Secondary = weak and secondary cavity-using species (Martin and Eadie 1999).

${ }^{\mathrm{d}}$ Shannon's diversity index (Zar 1999).

${ }^{\mathrm{e}}$ Number of species/plot (1 plot $\left.=0.785 \mathrm{ha}\right)$.

${ }^{\mathrm{f}}$ Number of animals/ha. 
Figure 1. Breeding counts of most commonly occurring bird species within all 50-m radius plots, Monongahela National Forest, 2000-2001 $(N=90)$. Counts reflect sums of yearly plot maximums per 2 counts.

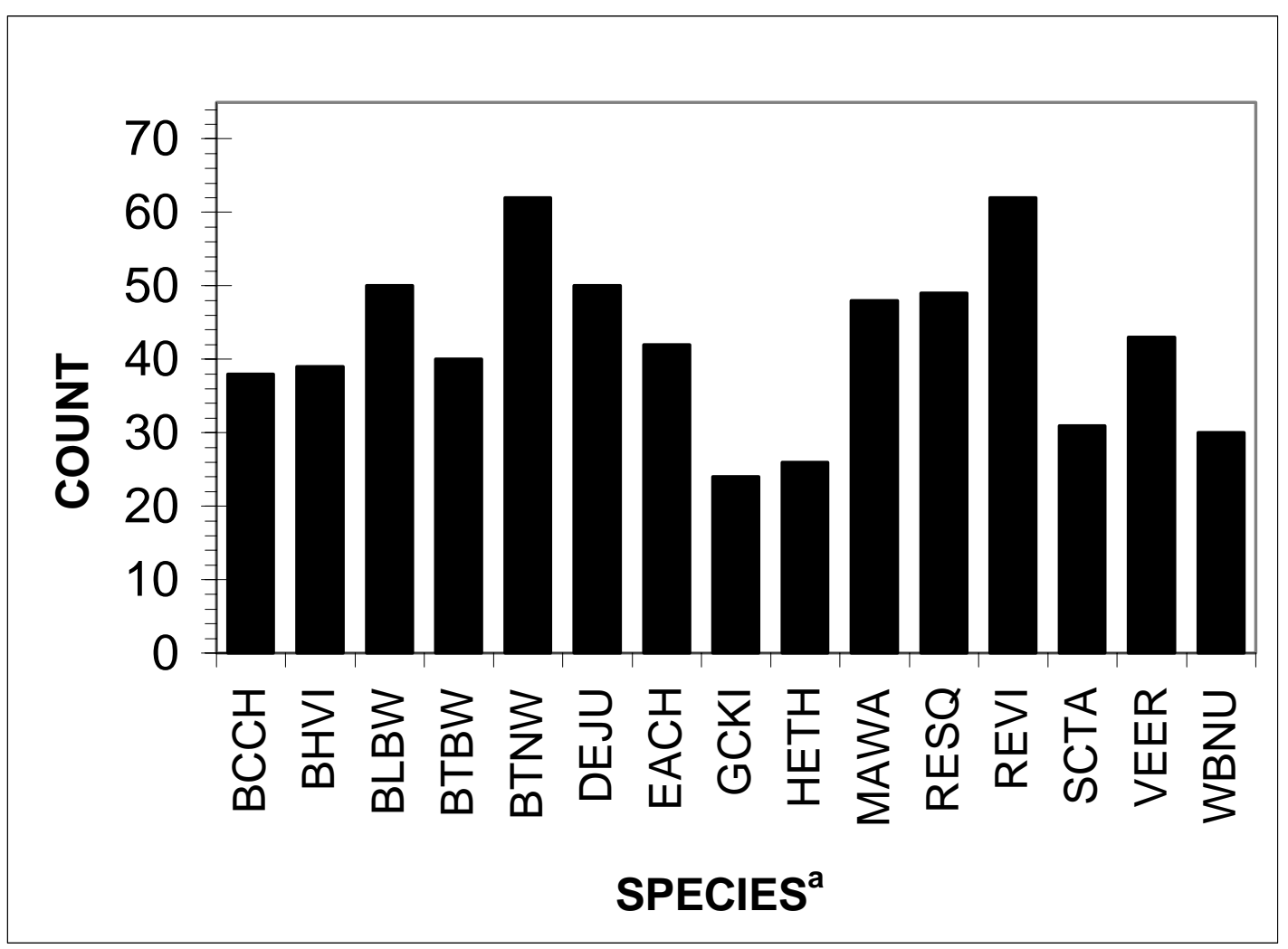

${ }^{a}$ Bird species abbreviations are as follows: $\mathrm{BCCH}$ - black-capped chickadee; BHVI blue-headed vireo; BLBW - Blackburnian warbler; BTBW - black-throated blue warbler; BTNW - black-throated green warbler; DEJU - dark-eyed junco; EACH eastern chipmunk; GCKI - golden-crowned kinglet; HETH - hermit thrush; MAWA magnolia warbler; RESQ - red squirrel; REVI - red-eyed vireo; SCTA - scarlet tanager; VEER - veery; and WBNU - white-breasted nuthatch. 
Appendix I. UTM coordinates for all 90 plots; the first 75 were used in cavity tree abundance analyses, Monongahela National Forest, West Virginia, 2000-2001.

\begin{tabular}{|c|c|c|}
\hline PLOT & UTM North & UTM East \\
\hline 1 & 4272459.879 & 624733.285 \\
\hline 2 & 4272169.147 & 624853.820 \\
\hline 3 & 4273900.580 & 625776.790 \\
\hline 4 & 4274983.562 & 600374.438 \\
\hline 5 & 4276332.769 & 597821.899 \\
\hline 6 & 4276454.611 & 598272.486 \\
\hline 7 & 4252282.661 & 608038.418 \\
\hline 8 & 4252127.839 & 608222.515 \\
\hline 9 & 4276737.529 & 600727.349 \\
\hline 10 & 4274394.091 & 600967.208 \\
\hline 11 & 4279116.184 & 600599.582 \\
\hline 12 & 4274184.370 & 625775.159 \\
\hline 13 & 4281968.012 & 605559.054 \\
\hline 14 & 4282066.356 & 605851.333 \\
\hline 15 & 4282243.942 & 606039.302 \\
\hline 16 & 4281717.693 & 605976.218 \\
\hline 17 & 4280290.125 & 608091.889 \\
\hline 18 & 4280352.317 & 608345.671 \\
\hline 19 & 4268462.699 & 610882.503 \\
\hline 20 & 4282473.706 & 597790.211 \\
\hline 21 & 4248436.190 & 607243.216 \\
\hline 22 & 4246640.320 & 610479.216 \\
\hline 23 & 4246823.782 & 610283.378 \\
\hline 24 & 4247075.943 & 610271.173 \\
\hline 25 & 4286202.851 & 607830.024 \\
\hline 26 & 4252327.833 & 609009.193 \\
\hline 27 & 4252329.255 & 608646.519 \\
\hline 28 & 4246821.844 & 609795.165 \\
\hline 29 & 4247030.633 & 610997.149 \\
\hline 30 & 4268256.024 & 610581.89 \\
\hline 31 & 4274108.614 & 626038.416 \\
\hline 32 & 4265810.548 & 613124.762 \\
\hline 33 & 4281431.066 & 600049.386 \\
\hline 34 & 4281261.838 & 596801.325 \\
\hline 35 & 4280279.589 & 596900.247 \\
\hline 36 & 4284746.479 & 605963.316 \\
\hline 37 & 4280821.829 & 607968.597 \\
\hline 38 & 4281308.182 & 607410.067 \\
\hline 39 & 4282495.183 & 608943.985 \\
\hline 40 & 4283987.845 & 608653.448 \\
\hline 41 & 4282304.458 & 608107.905 \\
\hline 42 & 4285980.643 & 609438.445 \\
\hline
\end{tabular}


Appendix I. Continued.

\begin{tabular}{lll}
\hline PLOT & UTM North & UTM East \\
43 & 4273440.492 & 625687.945 \\
44 & 4283964.317 & 639149.086 \\
45 & 4285418.278 & 610155.188 \\
46 & 4285179.337 & 610030.302 \\
47 & 4285600.183 & 608529.031 \\
48 & 4283504.725 & 605597.918 \\
49 & 4277728.466 & 599577.529 \\
50 & 4283548.242 & 597210.909 \\
51 & 4282724.247 & 639508.552 \\
52 & 4282937.918 & 639376.186 \\
53 & 4283183.522 & 639210.053 \\
54 & 4283433.006 & 639387.714 \\
55 & 4283663.111 & 639543.745 \\
56 & 4283868.575 & 639466.855 \\
57 & 4277869.467 & 601326.601 \\
58 & 4287867.652 & 606781.405 \\
59 & 4287554.328 & 606390.175 \\
60 & 4288150.247 & 606755.715 \\
61 & 4287261.933 & 606384.144 \\
62 & 4287082.532 & 606570.393 \\
63 & 4287445.282 & 607153.614 \\
64 & 4286287.202 & 607545.884 \\
65 & 4266021.625 & 612011.903 \\
66 & 4266577.783 & 611299.514 \\
67 & 4281561.869 & 599496.836 \\
68 & 4274396.884 & 598630.225 \\
69 & 4276298.766 & 600658.042 \\
70 & 4278000.044 & 601102.236 \\
71 & 4279395.147 & 600773.216 \\
72 & 4279597.871 & 600659.532 \\
73 & 4278831.156 & 600078.295 \\
74 & 4279177.228 & 600192.914 \\
75 & 4278043.767 & 599091.093 \\
76 & 4281761.161 & 599191.343 \\
77 & 4282104.418 & 598809.202 \\
78 & 4282653.544 & 597357.221 \\
79 & 4284123.973 & 597986.171 \\
80 & 4284099.888 & 598635.729 \\
81 & 4285897.699 & 606985.236 \\
82 & 4280940.555 & 606589.720 \\
83 & 4280859.083 & 605529.571 \\
84 & 4283629.214 & 605410.483
\end{tabular}


Appendix I. Continued.

\begin{tabular}{lll}
\hline PLOT & UTM North & UTM East \\
85 & 4285328.306 & 609149.605 \\
86 & 4283066.625 & 639701.853 \\
87 & 4283352.593 & 639652.736 \\
88 & 4252535.168 & 608823.207 \\
89 & 4272615.820 & 625239.836 \\
90 & 4272396.808 & 624230.976 \\
\hline
\end{tabular}


Appendix II. Mean basal area and stem counts per plot ( $0.78 \mathrm{ha})$, Red spruce - yellow birch cover type, Monongahela National Forest, West Virginia, 1999 - 2001.

\begin{tabular}{lccccc}
\hline & \multicolumn{2}{c}{ Basal Area $\left(\mathrm{m}^{2} / \mathrm{ha}\right)$} & & \multicolumn{2}{c}{ Stem count (stems/0.78 ha) } \\
\cline { 2 - 3 } \cline { 5 - 6 } Species & $\overline{\mathrm{X}}$ & $\mathrm{SE}$ & & $\overline{\mathrm{x}}$ & $\mathrm{SE}$ \\
\hline American beech & 0.689 & 0.294 & & 2.533 & 1.572 \\
Black cherry & 1.378 & 0.599 & & 1.333 & 3.188 \\
Eastern hemlock & 1.378 & 0.523 & & 5.467 & 3.026 \\
Red maple & 2.526 & 0.554 & & 9.433 & 3.353 \\
Red spruce & 13.932 & 1.298 & & 32.267 & 5.254 \\
Yellow birch & 6.507 & 0.922 & & 26.433 & 4.892 \\
Other & 0.689 & 0.250 & & 2.600 & 1.240 \\
\hline
\end{tabular}


Appendix III. Mean basal area and stem counts per plot (0.78 ha), Black cherry - maple cover type, Monongahela National Forest, West Virginia, 1999 - 2001.

\begin{tabular}{lccccc}
\hline & \multicolumn{2}{c}{ Basal Area $\left(\mathrm{m}^{2} / \mathrm{ha}\right)$} & & \multicolumn{2}{c}{ Stemcount (stems/0.78 ha) } \\
\cline { 2 - 3 } \cline { 5 - 6 } \multicolumn{1}{c}{ Species } & $\overline{\mathrm{x}}$ & $\mathrm{SE}$ & & $\overline{\mathrm{x}}$ & $\mathrm{SE}$ \\
\hline American beech & 3.827 & 0.841 & & 13.267 & 3.496 \\
Black cherry & 8.497 & 0.922 & & 8.800 & 1.496 \\
Red maple & 3.445 & 0.590 & & 11.067 & 2.570 \\
Sugar maple & 6.200 & 1.161 & & 10.967 & 2.607 \\
White ash & 1.225 & 0.361 & & 1.933 & 0.806 \\
Yellow birch & 2.603 & 0.792 & & 5.600 & 1.803 \\
Other & 2.832 & 0.711 & & 8.700 & 2.588 \\
\hline
\end{tabular}


Appendix IV. Mean basal area and stem counts per plot (0.78 ha), White oak - black oak Northern red oak cover type, Monongahela National Forest, West Virginia, 1999 - 2001.

\begin{tabular}{lccccc}
\hline \multirow{2}{*}{ Species } & \multicolumn{2}{c}{ Basal Area $\left(\mathrm{m}^{2} / \mathrm{ha}\right)$} & & \multicolumn{2}{c}{ Stem count $(\mathrm{stems} / 0.78 \mathrm{ha})$} \\
\cline { 2 - 3 } \cline { 6 - 6 } \cline { 5 - 6 } & $\overline{\mathrm{x}}$ & $\mathrm{SE}$ & & $\overline{\mathrm{x}}$ & $\mathrm{SE}$ \\
\hline Black locust & 0.842 & 0.301 & & 2.467 & 0.989 \\
Black oak & 1.990 & 0.658 & & 3.867 & 1.933 \\
Chestnut oak & 5.282 & 0.986 & & 10.200 & 2.392 \\
Hickory spp. & 1.225 & 0.377 & & 3.700 & 1.190 \\
Northern red oak & 7.731 & 0.898 & & 13.133 & 2.472 \\
Red maple & 3.292 & 0.685 & & 16.933 & 4.059 \\
Sugar maple & 1.684 & 0.527 & & 4.867 & 2.734 \\
White oak & 3.292 & 0.524 & & 7.700 & 2.569 \\
Other & 2.296 & 0.467 & & 6.800 & 2.567 \\
\hline
\end{tabular}


Appendix V. Percent of stems by damage class, of all inventory trees and all cavity trees, by species, Monongahela National Forest, West Virginia, 2000 - 2001.

\begin{tabular}{|c|c|c|c|c|c|c|c|c|}
\hline \multirow[b]{3}{*}{ Species } & \multicolumn{8}{|c|}{ Damage Class } \\
\hline & \multicolumn{2}{|c|}{ No damage } & \multicolumn{2}{|c|}{ Broken Top $^{\mathrm{a}}$} & \multicolumn{2}{|c|}{ Broken limb $^{b}$} & \multicolumn{2}{|c|}{ Limb and top } \\
\hline & $\mathrm{C}^{\mathrm{c}}$ & $\mathrm{I}^{\mathrm{d}}$ & $\mathrm{C}$ & I & $\mathrm{C}$ & $\mathrm{I}$ & $\mathrm{C}$ & I \\
\hline American beech (Fagus grandifolia) & 29.46 & 58.33 & 51.79 & 33.33 & 8.93 & 6.67 & 9.82 & 1.67 \\
\hline black cherry (Prunus serotina) & 63.64 & 91.54 & 18.18 & 3.08 & 18.18 & 5.38 & 0.0 & 0.0 \\
\hline black locust (Robinia pseudoacacia) & 49.25 & 81.82 & 38.81 & 18.18 & 10.45 & 0 & 1.49 & 0 \\
\hline black oak (Quercus velutina) & 60.0 & 96.2 & 16 & 3.85 & 20 & 0 & 4 & 0 \\
\hline chestnut oak (Quercus prinus) & 32.26 & 72.46 & 19.35 & 5.8 & 38.71 & 21.74 & 9.68 & 0 \\
\hline Northern red oak (Quercus rubra) & 51.35 & 83.65 & 18.92 & 1.92 & 27.03 & 14.42 & 2.7 & 0 \\
\hline red maple (Acer rubrum) & 67.1 & 92.0 & 25.7 & 7.1 & 7.14 & 0.89 & 0.0 & 0.0 \\
\hline red spruce (Picea rubens) & 9.52 & 90.37 & 90.48 & 9.09 & 0 & 0.53 & 0.0 & 0.0 \\
\hline sugar maple (Acer saccharum) & 62.6 & 90.7 & 29.0 & 5.6 & 7.48 & 3.74 & 0.93 & 0 \\
\hline white oak (Quercus alba) & 66.7 & 86.1 & 7.4 & 4.7 & 22.2 & 9.3 & 3.7 & 0.0 \\
\hline yellow birch (Betula alleghaniensis) & 37.4 & 81.5 & 43.4 & 10.9 & 12.1 & 6.7 & 7.2 & 0.8 \\
\hline
\end{tabular}

${ }^{\mathrm{a}}$ Bole broken at $>10 \mathrm{~cm}$.

${ }^{\mathrm{b}}$ Broken limb at $>10 \mathrm{~cm}$.

${ }^{\mathrm{b}}$ All cavity trees.

${ }^{\mathrm{c}}$ All inventory trees. 
Appendix VI. Percent of stems by decay class, of all inventory trees and all cavity trees, by species, Monongahela National Forest, West Virginia, 2000 - 2001.

\begin{tabular}{|c|c|c|c|c|c|c|c|c|c|c|c|c|c|c|}
\hline \multirow[b]{3}{*}{ Species } & \multicolumn{14}{|c|}{ Decay Class $^{\mathrm{a}}$} \\
\hline & \multicolumn{2}{|c|}{1} & \multicolumn{2}{|c|}{2} & \multicolumn{2}{|c|}{3} & \multicolumn{2}{|c|}{4} & \multicolumn{2}{|c|}{5} & \multicolumn{2}{|c|}{6} & \multicolumn{2}{|c|}{7} \\
\hline & $\mathrm{C}^{\mathrm{b}}$ & $\mathrm{I}^{\mathrm{c}}$ & $\mathrm{C}$ & I & $\mathrm{C}$ & I & $\mathrm{C}$ & I & $\mathrm{C}$ & I & $\mathrm{C}$ & I & $\mathrm{C}$ & I \\
\hline American beech (Fagus grandifolia) & 0.9 & 28.3 & 28.6 & 35.0 & 6.3 & 5.0 & 24.1 & 13.3 & 36.6 & 16.7 & 3.6 & 1.7 & 0.0 & 0.0 \\
\hline black cherry (Prunus serotina) & 22.7 & 78.5 & 40.9 & 16.9 & 4.6 & 0.0 & 13.6 & 0.8 & 9.1 & 2.3 & 9.1 & 1.5 & 0.0 & 0.0 \\
\hline black locust (Robinia pseudoacacia) & 0.0 & 9.1 & 17.9 & 45.5 & 1.5 & 0.0 & 38.8 & 18.2 & 40.3 & 27.3 & 1.5 & 0.0 & 0.0 & 0.0 \\
\hline black oak (Quercus velutina) & 44.0 & 76.9 & 40.0 & 19.2 & 0.0 & 0.0 & 4.0 & 3.9 & 12.0 & 0.0 & 0.0 & 0.0 & 0.0 & 0.0 \\
\hline chestnut oak (Quercus prinus) & 22.6 & 71.0 & 41.9 & 23.2 & 4.8 & 0.0 & 12.9 & 5.8 & 16.1 & 0.0 & 1.6 & 0.0 & 0.0 & 0.0 \\
\hline Northern red oak (Quercus rubra) & 27.0 & 84.6 & 54.1 & 13.5 & 0.0 & 0.0 & 8.1 & 0.0 & 10.8 & 1.9 & 0.0 & 0.0 & 0.0 & 0.0 \\
\hline red maple (Acer rubrum) & 21.4 & 76.8 & 51.5 & 16.1 & 5.7 & 0.0 & 12.9 & 3.6 & 5.7 & 2.7 & 1.4 & 0.0 & 1.4 & 0.9 \\
\hline red spruce (Picea rubens) & 4.8 & 80.2 & 4.8 & 6.4 & 19.1 & 3.2 & 52.4 & 8.6 & 0.0 & 10.7 & 14.3 & 0.5 & 4.8 & 0.0 \\
\hline sugar maple (Acer saccharum) & 24.1 & 79.4 & 42.6 & 14.0 & 5.6 & 2.8 & 15.7 & 2.8 & 11.1 & 0.9 & 0.9 & 0.0 & 0.0 & 0.0 \\
\hline white oak (Quercus alba) & 22.2 & 83.7 & 70.4 & 16.3 & 0.0 & 0.0 & 7.4 & 0.0 & 0.0 & 0.0 & 0.0 & 0.0 & 0.0 & 0.0 \\
\hline yellow birch (Betula alleghaniensis) & 13.3 & 53.8 & 22.9 & 26.9 & 12.1 & 5.9 & 22.9 & 5.0 & 22.9 & 5.0 & 6.0 & 2.5 & 0.0 & 0.8 \\
\hline
\end{tabular}

${ }^{\mathrm{a}}$ From Maser et al. (1979).

${ }^{\mathrm{b}}$ All cavity trees.

${ }^{\mathrm{c}}$ All inventory trees. 
Appendix VII. Logistic regression models based on presence of bird species on 90 plots,

Monongahela National Forest, West Virginia, 2000-2001.

\begin{tabular}{|c|c|c|c|c|}
\hline Species & Parameter $^{\mathrm{a}}$ & Estimate & $\chi^{2}$ & $p$ \\
\hline acadian flycatcher & overstory cover (\%) & 7.432 & 4.172 & 0.041 \\
\hline Empidonax virescens & elevation (m) & -0.021 & 15.664 & $<0.001$ \\
\hline \multirow[t]{2}{*}{$(n=15)$} & northern red oak basal area $\left(\mathrm{m}^{2} / \mathrm{ha}\right)$ & 1.360 & 5.000 & 0.025 \\
\hline & Hosmer-Lemeshow goodness-of-fit ${ }^{b}$ & & 4.714 & 0.788 \\
\hline American robin & overstory cover $(\%)$ & 7.432 & 4.172 & 0.041 \\
\hline Turdus migratorius & elevation (m) & -0.009 & 7.158 & 0.008 \\
\hline \multirow[t]{5}{*}{$(n=21)$} & black cherry density (stems/ha) & 0.961 & 8.281 & 0.004 \\
\hline & red maple density (stems/ha) & 0.585 & 4.000 & 0.046 \\
\hline & red spruce density (stems/ha) & 0.666 & 4.584 & 0.032 \\
\hline & yellow birch density (stems/ha) & 0.685 & 5.867 & 0.015 \\
\hline & Hosmer-Lemeshow goodness-of-fit ${ }^{b}$ & & 4.890 & 0.769 \\
\hline Blackburnian warbler & sugar maple basal area $\left(\mathrm{m}^{2} / \mathrm{ha}\right)$ & 0.787 & 8.643 & 0.003 \\
\hline \multirow{3}{*}{$\begin{array}{l}\text { Dendroica fusca } \\
\qquad(n=50)\end{array}$} & yellow birch basal area $\left(\mathrm{m}^{2} / \mathrm{ha}\right)$ & 0.749 & 15.531 & $<0.001$ \\
\hline & white oak density (stems/ha) & 0.747 & 5.892 & 0.015 \\
\hline & Hosmer-Lemeshow goodness-of-fit ${ }^{b}$ & & 3.900 & 0.866 \\
\hline black-throated & shrub cover $(<2 \mathrm{~m})(\%)$ & 3.589 & 10.524 & 0.001 \\
\hline blue warbler & elevation (m) & 0.011 & 10.313 & 0.001 \\
\hline \multirow{3}{*}{$\begin{array}{l}\text { Dendroica caerulescens } \\
\qquad(n=40)\end{array}$} & sugar maple basal area $\left(\mathrm{m}^{2} / \mathrm{ha}\right)$ & 0.744 & 7.348 & 0.007 \\
\hline & yellow birch basal area $\left(\mathrm{m}^{2} / \mathrm{ha}\right)$ & 0.470 & 6.058 & 0.014 \\
\hline & Hosmer-Lemeshow goodness-of-fit ${ }^{b}$ & & 7.897 & 0.444 \\
\hline \multirow{2}{*}{$\begin{array}{l}\text { black-throated } \\
\text { green warbler }\end{array}$} & basal area $\left(\mathrm{m}^{2} / \mathrm{ha}\right)$ & 4.944 & 3.568 & 0.059 \\
\hline & inventory density (stems/ha) & -4.732 & 6.929 & 0.009 \\
\hline \multirow{3}{*}{$\begin{array}{l}\text { Dendroica virens } \\
\qquad(n=62)\end{array}$} & elevation (m) & 0.011 & 14.291 & $<0.001$ \\
\hline & red spruce density (stems/ha) & -1.038 & 5.199 & 0.023 \\
\hline & Hosmer-Lemeshow goodness-of-fit ${ }^{b}$ & & 9.010 & 0.341 \\
\hline blue-headed vireo & understory cover $(>2 \mathrm{~m})(\%)$ & 1.834 & 2.952 & 0.086 \\
\hline $\begin{array}{l}\text { Vireo solitarius } \\
\qquad(n=39)\end{array}$ & Hosmer-Lemeshow goodness-of-fit ${ }^{\mathrm{b}}$ & & 9.010 & 0.341 \\
\hline Canada warbler & understory cover $(>2 \mathrm{~m})(\%)$ & -4.056 & 3.338 & 0.068 \\
\hline \multirow{2}{*}{$\begin{array}{l}\text { Wilsonia canadensis } \\
\qquad(n=10)\end{array}$} & shrub cover $(<2 \mathrm{~m})(\%)$ & 5.309 & 9.112 & 0.003 \\
\hline & Hosmer-Lemeshow goodness-of-fit ${ }^{b}$ & & 4.486 & 0.811 \\
\hline \multirow{4}{*}{$\begin{array}{l}\text { scarlet tanager } \\
\text { Piranga olivacea } \\
\qquad(n=31)\end{array}$} & basal area $\left(\mathrm{m}^{2} / \mathrm{ha}\right)$ & 4.919 & 4.359 & 0.037 \\
\hline & sugar maple density (stems/ha) & 1.444 & 9.941 & 0.002 \\
\hline & white oak density (stems/ha) & 1.077 & 12.613 & $<0.001$ \\
\hline & Hosmer-Lemeshow goodness-of-fit ${ }^{b}$ & & 7.910 & 0.442 \\
\hline
\end{tabular}


Appendix VI. Continued.

\begin{tabular}{|c|c|c|c|c|}
\hline Species & Parameter $^{\mathrm{a}}$ & Estimate & $\chi^{2}$ & $p$ \\
\hline Swainson's thrush & shrub cover $(<2 \mathrm{~m})(\%)$ & 3.517 & 7.827 & 0.005 \\
\hline Catharus ustulatus & yellowbirch density (stems/ha) & 0.525 & 6.484 & 0.011 \\
\hline$(n=17)$ & Hosmer-Lemeshow goodness-of-fit ${ }^{b}$ & & 4.456 & 0.726 \\
\hline veery & inventory density (stems/ha) & -2.252 & 4.379 & 0.036 \\
\hline Catharus fuscescens & understory cover (> 2m) (\%) & 2.854 & 5.519 & 0.019 \\
\hline \multirow[t]{3}{*}{$(n=43)$} & elevation(m) & 0.004 & 3.706 & 0.054 \\
\hline & sugar maple density (stems/ha) & 0.457 & 2.915 & 0.088 \\
\hline & Hosmer-Lemeshow goodness-of-fit ${ }^{b}$ & & 6.920 & 0.545 \\
\hline white-breasted nuthatch & basal area $\left(\mathrm{m}^{2} / \mathrm{ha}\right)$ & 4.180 & 3.209 & 0.073 \\
\hline Sitta carolinensis & shrub cover $(<2 m)(\%)$ & -1.861 & 3.565 & 0.059 \\
\hline \multirow[t]{2}{*}{$(n=30)$} & yellow birch density (stems/ha) & -0.915 & 11.054 & 0.001 \\
\hline & Hosmer-Lemeshow goodness-of-fit ${ }^{b}$ & & 5.568 & 0.696 \\
\hline wood thrush & overstory cover (\%) & 4.284 & 3.730 & 0.054 \\
\hline Hylocichla mustelina & shrub cover $(<2 \mathrm{~m})(\%)$ & -3.027 & 6.530 & 0.011 \\
\hline \multirow[t]{2}{*}{$(n=20)$} & yellowbirch density $(\%)$ & -0.527 & 3.423 & 0.064 \\
\hline & Hosmer-Lemeshow goodness-of-fit ${ }^{b}$ & & 4.442 & 0.815 \\
\hline winter wren & understory cover (> 2m) (\%) & -3.949 & 4.025 & 0.045 \\
\hline Troglodytes troglodytes & sugar maple basal area (m²/ha) & 2.911 & 4.822 & 0.028 \\
\hline \multirow[t]{3}{*}{$(n=12)$} & yellow birch basal area (m²/ha) & 0.857 & 7.326 & 0.007 \\
\hline & sugar maple density (stems/ha) & -2.788 & 2.926 & 0.087 \\
\hline & Hosmer-Lemeshow goodness-of-fit ${ }^{b}$ & & 4.442 & 0.815 \\
\hline
\end{tabular}

${ }^{a}$ All indpendent variables with $p<0.10$ are left in the model.

${ }^{\mathrm{b}}$ All $p>0.05$ show significant model fit (Cody and Smith 1997). 
Appendix VIII. Year 2000 individuals recorded in 50-meter point count plots in Monongahela National Forest, West Virginia. Numbers reflect maximum tally within each plot ( $n=10$ for each forest type).

\begin{tabular}{|c|c|c|c|c|}
\hline \multirow[b]{2}{*}{ Common Name } & \multirow[b]{2}{*}{ Scientific Name } & \multicolumn{3}{|c|}{ Forest Type $^{a}$} \\
\hline & & $\mathrm{S}$ & $\mathrm{N}$ & $\mathrm{C}$ \\
\hline Acadian flycatcher & Empidonax virescens & 0 & 1 & 0 \\
\hline alder flycatcher & Empidonax alnorum & 0 & 1 & 0 \\
\hline American crow & Corvus brachyrhyncos & 0 & 1 & 0 \\
\hline American redstart & Setophaga ruticilla & 0 & 0 & 1 \\
\hline American robin & Turdus migratorius & 1 & 0 & 0 \\
\hline Blackburnian warbler & Dendroica fusca & 12 & 4 & 8 \\
\hline black-and-white warbler & Mniotilta varia & 0 & 0 & 4 \\
\hline black-capped chickadee ${ }^{\mathrm{b}}$ & Poecile atricapilla & 3 & 2 & 2 \\
\hline black-throated blue warbler & Dendroica caerulescens & 9 & 2 & 1 \\
\hline black-throated green warbler & Dendroica virens & 4 & 11 & 7 \\
\hline blue jay & Cyanocitta cristata & 2 & 1 & 0 \\
\hline blue-headed vireo & Vireo solitarius & 2 & 3 & 3 \\
\hline brown creeper & Certhia americana & 3 & 2 & 0 \\
\hline brown-headed cowbird & Molothrus ater & 0 & 1 & 0 \\
\hline Canada warbler & Wilsonia canadensis & 6 & 1 & 0 \\
\hline cedar waxwing & Bombycilla cedrorum & 0 & 1 & 0 \\
\hline dark-eyed junco & Junco hyemalis & 10 & 1 & 0 \\
\hline downy woodpecker ${ }^{\mathrm{b}}$ & Picoides pubescens & 0 & 2 & 0 \\
\hline Eastern chipmunk $^{\mathrm{b}}$ & Tamias striatus & 0 & 5 & 15 \\
\hline Eastern gray squirrel $^{\mathrm{b}}$ & Sciuris carolinensis & 0 & 1 & 1 \\
\hline golden-crowned kinglet & Regulus satrapa & 13 & 2 & 0 \\
\hline Eastern wood-pewee & Contopus virens & 0 & 0 & 2 \\
\hline hairy woodpecker ${ }^{\mathrm{b}}$ & Picoides villosus & 0 & 1 & 1 \\
\hline hermit thrush & Catharus guttatus & 1 & 1 & 0 \\
\hline least flycatcher & Empidonax minmus & 0 & 1 & 0 \\
\hline magnolia warbler & Dendroica magnolia & 6 & 1 & 1 \\
\hline Northern parula & Parula americana & 0 & 1 & 1 \\
\hline ovenbird & Seirus aurocapillus & 0 & 2 & 2 \\
\hline pileated woodpecker ${ }^{\mathrm{b}}$ & Drycopus pileatus & 0 & 1 & 0 \\
\hline pine warbler & Dendroica pinus & 1 & 0 & 0 \\
\hline red crossbill & Loxia curvirostra & 3 & 0 & 0 \\
\hline red squirrel $^{\mathrm{b}}$ & Tamiasciuris hudsonicus & 5 & 3 & 0 \\
\hline red-breasted nuthatch ${ }^{\mathrm{b}}$ & Sitta canadensis & 6 & 0 & 0 \\
\hline red-eyed vireo & Vireo olivaceus & 3 & 11 & 10 \\
\hline red-tailed hawk & Buteo jamaicencis & 1 & 0 & 0 \\
\hline rose-breasted grosbeak & Pheucticus ludovicianus & 0 & 2 & 0 \\
\hline ruby-throated hummingbird & Archilocus colubris & 0 & 0 & 1 \\
\hline scarlet tanager & Piranga olivacea & 1 & 3 & 3 \\
\hline
\end{tabular}


Appendix VIII Continued.

\begin{tabular}{|c|c|c|c|c|}
\hline \multirow[b]{2}{*}{ Common Name } & \multirow[b]{2}{*}{ Scientific Name } & \multicolumn{3}{|c|}{ Forest Type $^{\mathrm{a}}$} \\
\hline & & $\mathrm{S}$ & $\mathrm{N}$ & $\mathrm{C}$ \\
\hline Swainson's thrush & Catharus ustulatus & 4 & 0 & 0 \\
\hline tufted titmouse ${ }^{\mathrm{b}}$ & Baeolophus bicolor & 0 & 1 & 3 \\
\hline veery & Catharus fuscescens & 3 & 1 & 4 \\
\hline white-breasted nuthatch ${ }^{\mathrm{b}}$ & Sitta carolinensis & 0 & 2 & 2 \\
\hline winter wren ${ }^{\mathrm{b}}$ & Troglodytes troglodytes & 3 & 1 & 0 \\
\hline wood thrush & Hylocichla mustelina & 0 & 5 & 4 \\
\hline yellow-bellied flycatcher & Empidonax flaviventris & 0 & 1 & 0 \\
\hline yellow-bellied sapsucker ${ }^{\mathrm{b}}$ & Sphyrapicus varius & 0 & 2 & 5 \\
\hline yellow-rumped warbler & Dendroica coronata & 2 & 0 & 0 \\
\hline \multicolumn{5}{|c|}{$\begin{array}{l}{ }^{2} \text { Forest types are as follows: } \\
\text { S - subalpine (red spruce - yellow birch) forest cover type; } \\
\mathrm{N} \text { - northern hardwood (black cherry - maple) forest cover type; and } \\
\mathrm{C} \text { - central hardwood (white oak - black oak - Northern red oak) forest cover type } \\
{ }^{\mathrm{D}} \text { Bird species demonstrates at least facultative use of tree cavities. }\end{array}$} \\
\hline
\end{tabular}


Appendix IX. Year 2001 individuals recorded in 50-meter point count plots in Monongahela National Forest, West Virginia. Numbers reflect maximum tally within each plot ( $n=30$ for each forest type).

\begin{tabular}{|c|c|c|c|c|}
\hline \multirow[b]{2}{*}{ Common Name } & \multirow[b]{2}{*}{ Scientific Name } & \multicolumn{3}{|c|}{ Forest Type $^{\mathrm{a}}$} \\
\hline & & $\mathrm{S}$ & $\mathrm{N}$ & $\mathrm{C}$ \\
\hline Acadian flycatcher & Empidonax virescens & 0 & 1 & 13 \\
\hline alder flycatcher & Empidonax alnorum & 0 & 1 & 0 \\
\hline American crow & Corvus brachyrhyncos & 0 & 0 & 1 \\
\hline American goldfinch & Cardeulis tristis & 4 & 1 & 0 \\
\hline American redstart & Setophaga ruticilla & 1 & 0 & 4 \\
\hline American robin & Turdus migratorius & 5 & 8 & 6 \\
\hline Blackburnian warbler & Dendroica fusca & 32 & 16 & 12 \\
\hline black-and-white warbler & Mniotilta varia & 0 & 0 & 9 \\
\hline black-capped chickadee ${ }^{\mathrm{b}}$ & Poecile atricapilla & 28 & 14 & 8 \\
\hline black-throated blue warbler & Dendroica caerulescens & 25 & 7 & 7 \\
\hline black-throated green warbler & Dendroica virens & 12 & 29 & 18 \\
\hline blue jay & Cyanocitta cristata & 2 & 8 & 8 \\
\hline blue-headed vireo & Vireo solitarius & 7 & 14 & 12 \\
\hline broad-winged hawk & Buteo platypterus & 1 & 0 & 0 \\
\hline brown creeper & Certhia americana & 10 & 7 & 0 \\
\hline brown-headed cowbird & Molothrus ater & 0 & 1 & 3 \\
\hline Canada warbler & Wilsonia canadensis & 10 & 0 & 0 \\
\hline cedar waxwing & Bombycilla cedrorum & 0 & 9 & 1 \\
\hline chestnut-sided warbler & Dendroica pensylvanica & 1 & 3 & 2 \\
\hline common raven & Corvus corax & 1 & 2 & 0 \\
\hline Cooper's hawk & Accipiter cooperii & 0 & 1 & 0 \\
\hline dark-eyed junco & Junco hyemalis & 30 & 23 & 4 \\
\hline downy woodpecker ${ }^{b}$ & Picoides pubescens & 2 & 8 & 12 \\
\hline Eastern chipmunk ${ }^{\mathrm{b}}$ & Tamias striatus & 0 & 33 & 37 \\
\hline Eastern towhee & Pipilo erythrophtmalmus & 2 & 0 & 0 \\
\hline Eastern gray squirrel $^{\mathrm{b}}$ & Sciuris carolinensis & 0 & 0 & 2 \\
\hline golden-crowned kinglet & Regulus satrapa & 19 & 5 & 0 \\
\hline Eastern wood-pewee & Contopus virens & 0 & 0 & 14 \\
\hline great crested flycatcher ${ }^{b}$ & Myiarchus crinitus & 0 & 1 & 3 \\
\hline hairy woodpecker ${ }^{\mathrm{b}}$ & Picoides villosus & 2 & 5 & 2 \\
\hline hermit thrush & Catharus guttatus & 5 & 16 & 0 \\
\hline hooded warbler & Wilsonia citrina & 0 & 0 & 1 \\
\hline indigo bunting & Passerina cyanea & 0 & 0 & 2 \\
\hline least flycatcher & Empidonax minmus & 0 & 2 & 5 \\
\hline magnolia warbler & Dendroica magnolia & 26 & 21 & 2 \\
\hline Northern flicker ${ }^{\mathrm{b}}$ & Colaptes auratus & 0 & 3 & 2 \\
\hline Northern waterthrush & Seirus noveboracensis & 1 & 0 & 0 \\
\hline Northern parula & Parula americana & 0 & 3 & 1 \\
\hline
\end{tabular}


Appendix IX. Continued.

\begin{tabular}{|c|c|c|c|c|}
\hline \multirow[b]{2}{*}{ Common Name } & \multirow[b]{2}{*}{ Scientific Name } & \multicolumn{3}{|c|}{ Forest Type $^{\mathrm{a}}$} \\
\hline & & $\mathrm{S}$ & $\mathrm{N}$ & $\mathrm{C}$ \\
\hline ovenbird & Seirus aurocapillus & 0 & 10 & 11 \\
\hline pileated woodpecker ${ }^{\mathrm{b}}$ & Drycopus pileatus & 2 & 0 & 2 \\
\hline pine warbler & Dendroica pinus & 1 & 0 & 0 \\
\hline red crossbill & Loxia curvirostra & 3 & 0 & 0 \\
\hline red squirrel $^{\mathrm{b}}$ & Tamiasciuris hudsonicus & 31 & 30 & 1 \\
\hline red-breasted nuthatch ${ }^{\mathrm{b}}$ & Sitta canadensis & 13 & 3 & 1 \\
\hline red-eyed vireo & Vireo olivaceus & 10 & 37 & 36 \\
\hline rose-breasted grosbeak & Pheucticus ludovicianus & 0 & 2 & 7 \\
\hline scarlet tanager & Piranga olivacea & 6 & 9 & 13 \\
\hline Swainson's thrush & Catharus ustulatus & 7 & 0 & 0 \\
\hline tufted titmouse $^{\mathrm{b}}$ & Baeolophus bicolor & 0 & 4 & 12 \\
\hline veery & Catharus fuscescens & 10 & 22 & 17 \\
\hline white-breasted nuthatch ${ }^{\mathrm{b}}$ & Sitta carolinensis & 0 & 14 & 27 \\
\hline winter wren ${ }^{\mathrm{b}}$ & Troglodytes troglodytes & 5 & 1 & 0 \\
\hline wood thrush & Hylocichla mustelina & 0 & 7 & 9 \\
\hline worm-eating warbler & Helmitheros vermivora & 0 & 0 & 2 \\
\hline yellow-billed cuckoo & Coccyzus americanus & 0 & 2 & 1 \\
\hline yellow-bellied sapsucker ${ }^{b}$ & Sphyrapicus varius & 1 & 0 & 11 \\
\hline $\begin{array}{l}\text { Forest types are as follows } \\
\mathrm{S} \text { - subalpine (red spruc } \\
\mathrm{N} \text { - northern hardwood } \\
\mathrm{C} \text { - central hardwood ( } \\
\text { Bird species demonstrates }\end{array}$ & $\begin{array}{l}\text { ow birch) forest cover typ } \\
\text { cherry - maple) forest cove } \\
\text { ak - black oak - Northern } r \\
\text { t facultative use of tree ca }\end{array}$ & $\begin{array}{l}\text {; anc } \\
\text { for }\end{array}$ & ver $t$ & \\
\hline
\end{tabular}

